Polít. Crim. Vol. 14, No 28 (Diciembre 2019), Art. 3, pp. 95-151. [http://politcrim.com/wp-content/uploads/2019/10/Vol14N28A3.pdf]

\title{
Prostitución ¿Es necesario castigar? Una propuesta feminista para Chile
}

\section{Is it necesary to punish prostitution? A feminist proposal for Chile}

\author{
Natalia Cabrera Morales \\ Egresada de Derecho. Ayudante de cátedra del Departamento de Derecho Penal y \\ Procesal Penal, Pontificia Universidad Católica de Valparaíso \\ natalia.c.cabrera.morales@gmail.com
}

Resumen: La presente investigación analiza el rol del Estado frente a la prostitución, considerando las dos posturas principales, el abolicionismo y la legalización, ambas feministas. El objetivo es develar cuál de ellas es más beneficiosa para los derechos de las prostitutas. Revisaremos la historia de la prostitución y el origen de su estigma, además de presentar los diferentes modelos de tratamiento. Luego de analizar los principales postulados del feminismo liberal y radical, enfrentaremos los argumentos del abolicionismo a los de la legalización. Luego, propondremos una postura moral y una jurídica en concordancia con los feminismos y respetuosas de los derechos de las prostitutas. Finalmente, concluiremos analizando el caso de Chile con una propuesta de regulación a la prostitución.

Palabras clave: Feminismos, ética sexual, consentimiento sexual, abolicionismo, legalización.

\begin{abstract}
This research analyzes the role of the State regarding prostitution, considering the two main positions, abolitionism and legalization, both feminists. The objective is to identify which position is more beneficial for prostitutes concerning their rights. We will review the history of prostitution and the origin of its social stigma in addition to presenting the different treatment models. After analyzing the main postulates of liberal and radical feminism, we contrast the arguments of abolitionism with those of legalization. Then, we will propose a moral and a legal position in accordance with feminisms and respectful of the rights of prostitutes. Finally, we will conclude analyzing the case of Chile with a proposed regulation to prostitution.
\end{abstract}

Keywords: Feminisms, sexual ethics, sexual consent, abolitionism, legalization.

\section{Introducción}

"[L]as mujeres que realizan ese trabajo son inmediatamente estigmatizadas, pertenecen a una categoría única: las víctimas. En Francia, la mayoría de ellas se niega a hablar públicamente con el rostro descubierto, porque saben que ese trabajo no debe asumirse. Hay que guardar silencio. (...) Se exige de ellas que estén sucias, mancilladas. Y si no dicen lo que hay que decir, si no se quejan del daño que les han hecho, si no cuentan cómo las han forzado, entonces lo pagan caro. No

\footnotetext{
* Parte del presente trabajo ha tenido como base mi Memoria de pregrado en la Pontificia Universidad Católica de Valparaíso, aprobada con nota máxima el año 2017. Tanto la Memoria como la realización de este artículo fueron guiadas por la profesora Dra. Laura Mayer Lux, a quien agradezco por su dedicación.
} 
nos da miedo que no sobrevivan, al contrario, nos da miedo que digan que ese trabajo no es tan aterrador como parece". ${ }^{1}$

Esta es la declaración de Virginie Despentes, una exitosa escritora francesa que ha redactado libros y películas, feminista y ex prostituta. En ella da cuenta del estigma que han sufrido las trabajadoras sexuales, también a manos del feminismo.

La prostitución es un fenómeno difícil de comprender. A menudo nos vemos influidos por aprensiones morales y sociales, por los discursos oficiales y por nuestra propia comprensión del sexo. Sin embargo, lo cierto es que es un fenómeno variable y los juicios absolutos sobre él deben tomarse con cuidado. Hoy, las trabajadoras sexuales reclaman un espacio en la sociedad y en la legalidad, se han organizado y han hecho oír sus voces.

Nuestra investigación busca estudiar el fenómeno desde una perspectiva feminista. Nos hemos preguntado cuál es la forma correcta en que el Estado debe abordarlo fuera de todo prejuicio y con pleno respeto a los derechos y autonomía de las mujeres. En las siguientes páginas, examinaremos principalmente dos de las posturas mayoritarias hoy en día; el abolicionismo y la legalización, ambas feministas. Nos preguntaremos por la conveniencia de la criminalización del cliente, resolviendo cuál debe ser el parámetro de intromisión del Estado, el que a su vez debe ser absolutamente respetuoso de los derechos de las mujeres. Nuestro objeto de estudio será la prostitución que entenderemos como "prestación voluntaria y negociada de servicios sexuales remunerados". 2 Cuando nos referimos a "voluntaria" queremos decir, carente de cualquier tipo de coacción o engaño, realizada por mayores de 18 años. Se excluyen de él, la trata de personas, la prostitución infantil, algunas formas de proxenetismo y la rufianería.

Nuestro objetivo es realizar una propuesta feminista, que en particular brinde respuesta a falta de regulación que existe en Chile, pero que pueda ser aplicada en cualquier país. Para ello hemos analizado los principales argumentos de la postura abolicionista, contrastándolos con las respuestas de la postura a favor de la legalización. Luego efectuamos un análisis en dos planos, por un lado el plano ético práctico, aventurándonos a adoptar una postura moral con respecto a la prostitución; y por otro lado el plano jurídico, estableciendo un parámetro que determine la intromisión del Derecho Penal. Nuestras posturas moral y jurídica se encuentran estrechamente intrincadas con los feminismos y tiene por objeto el empoderamiento femenino por sobre cualquier otra consideración.

Nos referiremos a las trabajadoras sexuales como prostitutas. Esto, porque consideramos que aquel término nada tiene de peyorativo ni degradante, por ende, no vemos razón para reemplazarlo.

\section{Referencia histórica a la prostitución}

\subsection{La prostitución en sociedades paganas}

\footnotetext{
${ }^{1}$ DESPENTES, Virginie, Teoría King Kong, España: Editorial Melusina, 2007, p. 57.

2 MAQUEDA, María Luisa, Prostitución, feminismos y derecho penal, Granada: Editorial Comares S.L, 2009, p. 61.
} 
La prostitución ha sido un fenómeno inmensamente variable a lo largo de la historia, tanto en lo relativo a la perspectiva social y moral respecto de quienes la ejercen y la consumen, como en cuanto a sus objetivos y rol en la comunidad. En la historia, ha revestido fundamentalmente tres formas, la prostitución doméstica, la sagrada o religiosa y la civil. ${ }^{3}$

La prostitución doméstica ocurre en una época en que los hombres vivían alejados unos de otros en el bosque, según Dufour, previa a las leyes del hombre y de la moral. La visita de un extraño constituía una bendición, llegando a considerarse incluso que podía ser un Dios. En ese contexto, la familia le brindaba toda la comodidad que podía, e incluso "[e]l marido cedía de buena voluntad su lecho y su mujer al huésped". ${ }^{4}$ A cambio de ello, el huésped, al despedirse, brindaba a la mujer un regalo a cambio de su hospitalidad. Esta forma de prostitución constituía un "servilismo sexual" que las mujeres estaban obligadas a cumplir a requerimiento de sus padres o esposos. ${ }^{5}$

La prostitución sagrada, muchas veces vinculada a la doméstica, era realizada como ofrenda o forma de conectarse con los dioses generalmente ligados a la sexualidad como Afrodita. Una de estas manifestaciones se realizaba en Babilonia, donde las mujeres debían tener sexo con un desconocido al menos una vez en su vida en el templo de Afrodita (Mylitta, le llamaban los asirios). ${ }^{6}$ Cosa similar ocurría en Armenia, en un recinto aledaño al templo de la diosa Anaitis, en donde vivían por un largo periodo de tiempo jóvenes (hombres y mujeres) del país, que pertenecían a algunas de las familias más distinguidas. Ahí, solo podían ingresar extranjeros que pagaban por las relaciones con un regalo. Las jóvenes que terminando su servicio a la diosa salían del templo eran las más solicitadas en matrimonio por los hombres y mientras más extranjeros hubieren recibido, más requeridas eran en matrimonio. ${ }^{7}$ Para los fenicios estaba Astarté, una diosa/dios, que poseía tanto el sexo masculino como el femenino, y que personificaba la deificación a los genitales. En los cultos nocturnos a esta diosa, los hombres se vestían como mujeres y las mujeres como hombres. ${ }^{8}$ Más curioso aún es el caso de Lidia, donde las mujeres ejercían la prostitución (siempre consagradas a una diosa) para obtener el dinero que sería destinado a su dote y así tener derecho a elegir esposo, quien estaba imposibilitado para rehusarse a la oferta. ${ }^{9}$

Las utilidades provenientes de esta actividad regularmente estaban destinadas al mantenimiento del templo y de los que vivían en él. ${ }^{10}$ La prostitución sagrada se erigía como un culto a los dioses de la sensualidad, femeninos, masculinos y hermafroditas. Era en realidad un culto a la misma sexualidad, como expresión de placer y diversidad, tal como señala Dufour: "Toda el Asia menor abrazó con entusiasmo un culto que divinizaba las pasiones y apetitos sensuales". ${ }^{11}$

\footnotetext{
${ }^{3}$ DUFOUR, Pedro, Historia de la prostitución en todos los pueblos del mundo, Barcelona: Juan Pons, 1870 , pp. 8-9.

${ }^{4}$ DUFOUR, Historia de la prostitución, cit. nota $\mathrm{n}^{\circ} 3, \mathrm{p} .10$.

${ }^{5}$ GARRIDO, Luis, La prostitución: Estudio jurídico y criminológico, Madrid: Edersa, 1992, p 31.

${ }^{6}$ RUBIO, Gonzalo, “¿Vírgenes o meretrices? La prostitución sagrada en el oriente antiguo”, Gerión, n. ${ }^{\circ}$ 17, 1999, pp. 129-148, pp. 129 y 130.

${ }^{7}$ DUFOUR, Historia de la prostitución, cit. nota $n^{\circ} 3$, p. 25.

${ }^{8}$ DUFOUR, Historia de la prostitución, cit. nota ${ }^{\circ} 3$, p. 26.

${ }^{9}$ DUFOUR, Historia de la prostitución, cit. nota $n^{\circ} 3$, p. 30.

${ }^{10}$ GARRIDO, La prostitución, cit. nota ${ }^{\circ} 5$, p. 32.

${ }^{11}$ DUFOUR, Historia de la prostitución, cit. nota $\mathrm{n}^{\circ}$ 3, p. 29.
} 
La comercialización del sexo por motivos no divinos empieza a definirse gradualmente. Quizás una de sus primeras manifestaciones se encuentra en Egipto, donde las hijas de Ramses y Cheope se prostituyen para beneficio de sus padres, pero también propio. Ahí es donde múltiples y famosas prostitutas construyen su riqueza y adoración. Muchas veces entablando relaciones con sus clientes y haciéndose de su poder incluso mejor que ellos. Las leyes egipcias protegían y autorizaban esta actividad, no vinculándola con una divinidad ni con la hospitalidad, tratándose en consecuencia de prostitución legal. ${ }^{12}$ De la prostitución legal incluso se beneficiaron los gobiernos. Calígula, en Roma, cobraba la octava parte de las ganancias de las prostitutas. ${ }^{13}$ Sin embargo, existían clases de prostitutas que eran inmunes a todo control estatal, como por ejemplo las "hetairas" en Grecia, cortesanas que se relacionaban con los filósofos de la época y que eran de alto rango social. ${ }^{14}$

Uno de los antecedentes del reglamentarismo y también de la esclavitud sexual, provienen de Roma, en el siglo III ac. Ahí se ordenaba a las prostitutas la inscripción en un registro especial y el porte de una cartilla. Se regulaba también la esclavitud legal de la mujer e incluso se criaban niñas desde la infancia para dedicarse a este oficio. Ellas eran destinadas a un mercader a perpetuidad, que podía venderlas a otro individuo con la condición de que siguieran ejerciendo la prostitución. ${ }^{15}$

\subsection{Prostitución en las sociedades judeo-cristianas}

Es probable que las primeras manifestaciones de la represión a la prostitución hayan sido iniciativa de Moisés, quien persiguió tanto la prostitución sagrada como la legal perdurando, sin embargo, la hospitalaria. No obstante, las catástrofes de Babilonia y el diluvio se relacionan en la Biblia con la furia de Dios debida al libertinaje sexual, expresado en la prostitución en todas sus formas. ${ }^{16}$ La ley de Moisés prohibía el ejercicio de la prostitución, pero permitía su consumo, lo cual es ilustrativo de la doble moral imperante aún hoy. Esta ley además sancionaba las relaciones homosexuales entre hombres, con animales y con una mujer durante su menstruación con la pena de muerte.

Esta regulación no solamente tuvo como fundamento el enojo de Dios, sino también razones de higiene y orden público. La regulación creada por el profeta parece ser el origen de un fuerte reglamentarismo, que establecía drásticos controles policiales a prostitutas y enfermos, quienes también eran vistos como impuros ${ }^{17}$. El caudillo hebreo desplegó todo el control y represión contra las mujeres hebreas, y con la excusa del control de las enfermedades llegó incluso a asesinar a todas las mujeres que no fueran vírgenes, siendo quizás este uno de los hitos que marcaron la glorificación de la virginidad y el control moral. Sin embargo, dichos rigores se aplicaron únicamente contra mujeres hebreas y no contra las extranjeras que ejercían libremente la prostitución, ni contra los hebreos que la consumían. Es ilustrativo el hecho de que

\footnotetext{
${ }^{12}$ DUFOUR, Historia de la prostitución, cit. nota $\mathrm{n}^{\circ} 3$, pp. 36 y ss.

${ }^{13}$ GONZALEZ, Manuel: Regulación penal del meretricio, Santiago, Librotecnia, 2009, p. 83.

${ }^{14}$ GONZALEZ, Regulación penal del meretricio, cit., nota ${ }^{\circ} 13$, p. 82.

${ }^{15}$ GARRIDO, La prostitución, cit. nota ${ }^{\circ} 5$, p. 34.

${ }^{16}$ DUFOUR, Historia de la prostitución, cit. nota ${ }^{\circ} 3$, pp. 43 y ss.

${ }^{17}$ DUFOUR, Historia de la prostitución, cit. nota $\mathrm{n}^{\circ} 3$, p. 50.
} 
Moisés era asiduo visitador de las extranjeras e incluso tomó a una de ellas, pagana, como concubina, a sus más de 100 años. ${ }^{18}$

No fue hasta la era cristiana que la religión se propone combatir la prostitución con el objeto de terminar con ella, predicando en cambio la abstinencia y castidad. ${ }^{19}$ Pero no se limitó a la prostitución, sino que se abocó a la erradicación de todos los placeres y solo en caso de no poder contenerse, quien sintiera deseos debía casarse, ya que se ofrecía la santificación del alma en oposición a la del cuerpo. Durante los tres primeros siglos del cristianismo hubo una "guerra intransigente de la moral contra la prostitución". ${ }^{20}$

La divinización esta vez de la virginidad y la abstinencia siguió una larga tradición en el cristianismo. San Bernardo en el siglo XI decía: “¿Qué puede imaginarse más bello que la sublime virtud de la castidad? (...) Ella purifica un cuerpo que se había sacado de una masa sucia y corrompida; de un enemigo hace un amigo, de un hombre, un ángel". ${ }^{21}$ Otros como San Clemente aseverarían luego que el único fin del sexo era la procreación. ${ }^{22}$ La moral cristiana vendría a afirmar el pudor, la vergüenza, la virginidad, la abstinencia, el arrepentimiento y la culpa como valores imprescindibles para acceder al "cielo", y de faltar aquellos, el cristiano debía soportar extensas penitencias e incluso el fuego de un temible "infierno".

En la época medieval, pese a que en algunos lugares eran celebradas con flores, la represión no hizo más que aumentar. Las múltiples ordenanzas existentes eran minuciosas. Les negaban el derecho a la ciudadanía, las obligaban a usar trajes especiales para distinguirlas de las mujeres "honradas", e incluso sus tumbas estaban separadas de las del resto. En esta época prosperó la prostitución en las fiestas, las expediciones militares y los puertos. La iglesia no perdería su parte de tanta prosperidad. El Papa Clemente VII obligaba a las prostitutas a entregar la mitad de sus ganancias a la iglesia. ${ }^{23}$

Esta nueva moral sexual y la represión que trajo aparejada, vendrían a imponerse durante toda la era cristiana incluso hasta nuestros días, sin embargo, nunca lograron su objetivo, a saber, terminar con la prostitución. No obstante, la estigmatización del sexo fue mutando poco a poco, el aporte de disciplinas como el arte, la medicina, la psicología, la antropología, la sociología, etc. ${ }^{24}$ fue creando un ambiente propicio para cambiar la visión de la sociedad en torno al sexo y de paso en torno a la prostitución.

\footnotetext{
${ }^{18}$ DUFOUR, Historia de la prostitución, cit. nota $\mathrm{n}^{\circ}$ 3, p. 58.

${ }^{19}$ DUFOUR, Historia de la prostitución, cit. nota $\mathrm{n}^{\circ} 3$, p. 539.

${ }^{20}$ DUFOUR, Historia de la prostitución, cit. nota $\mathrm{n}^{\circ}$ 3, p. 549.

${ }^{21}$ Citado por DUFOUR, Historia de la prostitución, cit. nota ${ }^{\circ} 3$, p. 549.

${ }^{22}$ DUFOUR, Historia de la prostitución, cit. nota $\mathrm{n}^{\circ} 3$, p. 553.

${ }^{23}$ GARRIDO, La prostitución, cit. nota $\mathrm{n}^{\circ} 5$, pp. 37 y 38 .

${ }^{24}$ Freud fue uno de los que con sus estudios enseñó la importancia de la sexualidad para los individuos. Ellis también fue trascendente en este aspecto, ya que demostró que el deseo sexual es igual para hombres y para mujeres, y que la masturbación no genera daños en la salud. En el mismo sentido se muestran Masters y Johnson con su libro "Respuesta sexual humana", donde se constata que el deseo sexual no termina con el embarazo, la menopausia o la menstruación. Así mismo, Share Hite con los "Informes Hite sobre Sexualidad Masculina y Femenina", se refiere al problema de que la sexualidad femenina giraba en torno a la respuesta sexual masculina y el coito. Véase VERA-GAMBOA, Ligia, "Historia de la medicina. Historia de la sexualidad”, Revista Biomedica, vol. 9, n², 1998, pp. 116-121, pp. 120 y ss.
} 


\subsection{Prostitución en nuestros días}

A fines de la segunda guerra mundial comenzó un periodo de renovación de la moral sexual, con la invención de la píldora anticonceptiva y la diversificación de los medios contraceptivos, el movimiento hippie, la masificación de la pornografía y del cine y el descubrimiento de la penicilina, que ayudaría a controlar las enfermedades de transmisión sexual. Todos estos factores provocaron la aceptación del sexo extramarital, la homosexualidad y la disociación de la procreación y el sexo.

Alrededor de los años sesenta se produjo la revolución sexual ${ }^{25}$ y con ella un cambio trascendental en la forma de ver y practicar el sexo. Ella indudablemente traería aparejados cambios en la concepción del rol de la mujer en la sociedad, acompañados de un impulso en la afirmación personal y material de las mujeres. ${ }^{26} \mathrm{El}$ feminismo alzaría aquí su segunda ola, marcada por la lucha para alcanzar la libertad sexual y personal, con el lema "lo personal es político" de Simone de Beauvoir. Las feministas exigirían la legalización de la píldora, del aborto y del divorcio, instalando con fuerza estos temas en la palestra pública.

Con el auge de la sociedad de consumo la revolución también significaría la diversificación y liberación del comercio sexual. La prostitución comenzó a vincularse con las industrias del ocio y de lo visual, variando su oferta y también su demanda, que cada vez exigía servicios más exóticos e innovadores. Esto confirmaba la idea de la prostitución como un fenómeno esencialmente variable, según el cambio en los gustos, las circunstancias sociales y la circulación del dinero. Así, se abre paso a los espectáculos eróticos y la pornografía, creándose multinacionales de la industria del sexo. ${ }^{27}$ Todo esto posibilitado por un cambio de paradigma en torno al sexo y a la normalización de la prostitución. La difusión de la pornografía sería uno de los factores más importantes en la nueva identidad de la prostitución. Estas circunstancias fueron tierra fértil para poderosas industrias, diversificación de los servicios y también para la explotación.

\subsection{Análisis e importancia de la historia}

El relato de la historia de la prostitución no se hace con meros fines anecdóticos. Su objetivo es ilustrar al lector en relación con las diferentes concepciones que han existido a lo largo de los tiempos sobre la moral sexual, la libertad y la prostitución, y los vínculos que se establecen entre estos conceptos y factores que podrían parecer accesorios, como la religión y la economía. Frecuentemente se dice que la prostitución es el oficio más antiguo, pero pocas veces se tienen en cuenta los diversos elementos que la han influido y las concepciones sociales que se han tenido respecto de ella.

Carecer de una perspectiva histórica sobre la prostitución nos puede llevar a pensar que siempre ha sido una actividad relegada, menospreciada y prohibida, idea muy lejana a la realidad. En efecto, a la luz de los primeros relatos, podemos constatar que hubo un tiempo en que era una actividad prestigiosa, socialmente respetable e íntimamente

\footnotetext{
${ }^{25}$ A ella se refiere latamente desde la perspectiva de las mujeres y el feminismo OSBORNE, Raquel, " $\mathrm{La}$ construcción sexual de la realidad", Madrid: Ediciones cátedra, 1993, pp. 169 y ss.

${ }^{26}$ HITE, Shere, El orgasmo femenino, teorías sobre la sexualidad humana, Barcelona: Editorial Zeta Bolsillo, 2008, p. 15.

${ }^{27}$ MAQUEDA, Prostitución, feminismos y derecho penal, cit. nota n ${ }^{\circ}$ 4, pp. 14 y ss.
} 
conectada, y no en riña con la religiosidad. En una época ajena al cristianismo el fenómeno era socialmente aceptado y en ocasiones ampliamente extendido. Es cierto que muy probablemente estos relatos provengan de visiones masculinizadas de la historia; o que los hechos hayan tenido como causa imperativos de género creados para satisfacer el deseo masculino. Pero no podemos desconocer que el ejercicio de la prostitución era en parte ajeno al rechazo social, al estigma moral e incluso podía erguirse como instrumento de emancipación femenina o expresión de una sexualidad divinizada y glorificada, y no impura o inmoral, como se concibe hoy en día. Es aquí donde debemos preguntarnos dónde surge el estigma moral para quien ejerce la prostitución y de qué manera, así como sobre qué base aquellas que eran "enviadas de las diosas" pasan a ser desviadas y castigadas ocupando el último lugar en la escala social femenina.

Este análisis histórico nos demuestra que el tratamiento de la prostitución -incluso el tratamiento penal- está estrechamente ligado con la moral. Nos sitúa en la problemática de si la prostitución es o no una institución intrínsecamente inmoral o si, por el contrario, el que haya sido catalogada de inmoral obedece a cuestiones circunstanciales carentes de racionalidad. Kant afirma que la moral debe predicarse de forma absoluta, para todos los seres racionales y no en condiciones contingentes; es decir, debe ser transversal a todos los tiempos, culturas y religiones, puesto que se funda en la razón. ${ }^{28}$ La historia de la prostitución es un buen punto de partida para adentrarnos en las consideraciones éticas y morales pertinentes, cuestión que trataremos más adelante.

Este análisis histórico además nos muestra los fundamentos, raíces filosóficas e ideas inspiradoras de los principales modelos de tratamiento de la prostitución y también las consecuencias que tuvieron sobre la sociedad. Así, los modelos reglamentarista y prohibicionista se ven estrechamente ligados con la moral cristiana, mientras que en las sociedades paganas la regulación fue más bien permisiva e incluso fomentaba la prostitución. Podemos ver también que a partir de la revolución sexual las ideas feministas comienzan a afianzarse en nuestra sociedad y ellas serán las principales promotoras de las nuevas formas de tratamiento de la prostitución.

\section{Modelos de regulación de la prostitución}

\subsection{Reglamentarismo}

El reglamentarismo es quizás una de las más antiguas respuestas frente a la prostitución, aunque su auge se produjo en la segunda mitad del siglo XIX. Su idea madre es que la prostitución es inmoral, dañina e indeseada, pero, sin embargo, un mal necesario o al menos imposible de erradicar. Frente a esto, resulta indispensable regular diferentes aspectos de la misma.

Lo que caracteriza la filosofía de este modelo es sin lugar a dudas el control, ${ }^{29}$ que no tiene otro fin que la protección del cliente y de la sociedad frente a la prostituta, que es percibida como una amenaza. Uno de los principales objetivos de este modelo es la regulación sanitaria, a través de cartillas en donde consta el estado de salud de quienes ejercen el meretricio. Se promueve el control, principalmente a través de un examen

\footnotetext{
${ }^{28}$ KANT, Emanuel, “Fundamentación de la metafísica de las costumbres”, España: Editorial EspasaCalpe, 1977, especialmente pp. 58 y ss.

${ }^{29}$ GARRIDO, La prostitución, cit. nota ${ }^{\circ} 5$, p. 56.
} 
médico periódico, para así evitar el contagio de enfermedades venéreas. Quienes son portadoras de aquellas, frecuentemente son obligadas a realizar tratamientos y a cesar el ejercicio de su oficio. El control está exclusivamente radicado en quien ejerce la prostitución, olvidando por completo a los clientes, quienes son los que eventualmente las contagian. Otro de los objetivos de este modelo es la vigilancia policial. Solamente se permite el ejercicio de esta actividad en lugares delimitados y cumpliendo ciertos requisitos. Fuera de estos supuestos, las prostitutas son fuertemente perseguidas por las entidades policiales. A todo esto se suma el control moral, ya que la prostitución es vista como fuente de desorden social e indecencia, considerada un mal ejemplo para las mujeres honorables y la institución familiar. ${ }^{30}$ Con todo esto se las forzaba a aceptar su estatus de "mujeres públicas" y se terminaba con sus relaciones de vecindad y apoyo, resultando ellas aisladas. ${ }^{31}$

Este sistema resulta sumamente desventajoso para la prostituta, ya que, en primer lugar, no le brinda ninguna clase de protección frente a la arbitrariedad policial y la condena a la precarización laboral; en segundo lugar, otorga cierta cobertura legal al proxenetismo y la rufianería; ${ }^{32}$ en tercer lugar, además de hacerlas únicas responsables del contagio de enfermedades venéreas, ignorando la participación del cliente, el control sanitario no ha "servido en ninguna época ni en ningún país para reducir los estragos causados por las enfermedades venéreas". 33

\subsection{Abolicionismo primigenio}

En sus inicios, el abolicionismo se erige como un movimiento contrario al reglamentarismo, que se proponía acabar con la reglamentación estatal de la prostitución, vigente en casi todos los países del mundo. ${ }^{34}$ Este sistema fue apoyado por feministas y radicales, así como también por protestantes ingleses y suizos. Dirigidos en Inglaterra por Josephine Butler, quien tenía experiencia política en las campañas contra la esclavitud de los negros, es a partir de ahí que se comienza a delimitar el movimiento. $\mathrm{Su}$ blanco de ataque fueron las "contagious disease acts", leyes que otorgaban a los hombres, jueces, médicos y policías, el control sobre el cuerpo de las mujeres en aras a una supuesta protección de la salud pública. ${ }^{35}$ Se culpaba a las mujeres que ejercían este oficio del deterioro de la salud de toda la población sana y cualquier mujer podía ser acusada de ejercer la prostitución, bastaba con que un policía la señalase. Se les obligaba a someterse a intrusivos y poco higiénicos exámenes de salud, que determinarían su internación en hospitales. Si no accedían a realizárselos debían ir a la cárcel, situación que era preferida por muchas mujeres, ya que el examen suponía un alto riesgo de sufrir desgarros, infecciones o desangrarse. Ellas, además, eran asumidas culpables, debiendo demostrar su inocencia y careciendo de los derechos de cualquier imputado. ${ }^{36}$ La iniciativa de Butler no sería localizada, sino que se extendería por varios países de Europa, lanzando una cruzada internacional contra la reglamentación de la prostitución. Como parte de los primeros abolicionistas, también se encontraba John

\footnotetext{
${ }^{30}$ MAQUEDA, Prostitución, feminismos y derecho penal, cit., nota $\mathrm{n}^{\circ} 4$, p. 6.

${ }^{31}$ MAQUEDA, Prostitución, feminismos y derecho penal, cit., nota ${ }^{\circ} 4$, p. 5.

${ }^{32}$ GARRIDO, La prostitución, cit., nota ${ }^{\circ} 5$, p. 57.

${ }^{33}$ GARRIDO, La prostitución, cit., nota ${ }^{\circ} 5$, p. 57.

${ }^{34}$ GARRIDO, La prostitución, cit., nota $\mathrm{n}^{\circ} 5$, p. 57.

${ }^{35}$ DE MIGUEL, Ana; PALOMO, Eva, "Los inicios de la lucha feminista contra la prostitución: Políticas de redefinición y políticas activistas en el sufragismo inglés", Brocar, n 35, 2011, pp. 315-334, p 324.

${ }^{36}$ DE MIGUEL; PALOMO, "Los inicios de la lucha feminista" cit. nota ${ }^{\circ} 35$, pp. 324 y ss.
} 
Stuart Mill, quien sería férreo opositor a estas leyes en el parlamento inglés. ${ }^{37}$ A la luz de estas ideas es que comienza la criminalización del proxeneta, traficante y rufián, ${ }^{38}$ considerándoseles como una especie de esclavistas.

El abolicionismo surge como un movimiento que propugna por los derechos de las mujeres y la libertad, manifestándose en contra de la policía de costumbres y el encierro, exigiendo en consecuencia la derogación de la estricta regulación estatal de la prostitución, en particular del examen de salud periódico. ${ }^{39}$ Las propulsoras de este modelo veían la regulación como un sacrificio de libertades femeninas para la satisfacción del deseo masculino. Ellas fueron las primeras en considerar a los hombres como responsables y sostenedores de la prostitución, oponiéndose a la visión de que las prostitutas eran inmorales incitadoras del deseo masculino; así como también culpaban a los proxenetas y clientes de la masificación de las enfermedades de transmisión sexual. $^{40}$

Sin embargo, también se ha criticado a estas abolicionistas, en cuanto a que eran mujeres burguesas que tenían un ideal de castidad femenina, para quienes las prostitutas representaban una amenaza, "la otra", una alternativa denigrante y sexualizada ante la feminidad maternal y doméstica. Consideraban a las prostitutas como agentes involuntarios de su propia historia. Estas abolicionistas primigenias se concebían a sí mismas como las hermanas mayores, muchas de ellas declararían una guerra abierta contra la sexualidad extraconyugal. ${ }^{41} \mathrm{Al}$ parecer no eran las prostitutas quienes debían y podían decidir e incidir en las políticas públicas, sino estas mujeres mejor educadas. El abolicionismo se convertiría en una lucha contra la prostitución, decretando un patrón único de castidad y manifestándose a través de drásticas reacciones policiales en burdeles y en la calle. Este movimiento formaría un pacto con el puritanismo, volviéndose conservador y viendo en la lucha contra la prostitución la oportunidad de circunscribir el sexo únicamente al matrimonio. ${ }^{42}$ Todo ello contribuiría al aumento de la posición de clandestinidad y vulnerabilidad de las prostitutas. ${ }^{43}$

Ambos, el reglamentarismo y el abolicionismo, terminarían siendo sistemas fuertemente moralizadores y controladores. Ellos buscaban imponer una visión única de la sexualidad, la conyugal heterosexual, identificando a cualquier alternativa a ella como "portadora del mal". 44

\footnotetext{
${ }^{37}$ DE MIGUEL; PALOMO, "Los inicios de la lucha feminista" cit. nota $n^{\circ} 35$, pp. 328 y ss.

38 JIMÉNEZ DE ASÚA, Luis, "La protección penal del pudor público", El criminalista, tomo V, Buenos Aires: Editorial Víctor P. de Zavalía, 1961, p. 80. Citado por GONZALEZ: Regulación penal del meretricio, cit. nota $\mathrm{n}^{\circ} 13$.

${ }^{39}$ GONZALEZ, Regulación penal del meretricio, cit. nota ${ }^{\circ} 13$, p. 100.

${ }^{40}$ DE MIGUEL; PALOMO, "Los inicios de la lucha feminista", cit. nota ${ }^{\circ} 35$, pp. 322 y ss.

${ }^{41}$ Sobre este punto, ampliamente, WALKOWITZ, Judith, Prostitution and Victorian Society, Cambridge: Cambridge University Press, 1980.

42 VILLACAMPA, Carolina, "Políticas de criminalización de la prostitución: Análisis crítico de su fundamentación y resultados", Revista de derecho penal y criminología, 3.a Época, n7, 2012, pp. 81141 , p. 85.

${ }^{43}$ MAQUEDA, Prostitución, feminismos y derecho penal, cit. nota ${ }^{\circ} 4$, p. 7 .

${ }^{44}$ MAQUEDA, Prostitución, feminismos y derecho penal, cit. nota ${ }^{\circ} 4$, p. 7 .
} 


\subsection{Prohibicionismo}

Otra respuesta al reglamentarismo fue el prohibicionismo. Mientras el reglamentarismo acepta la prostitución como un mal necesario, imposible de erradicar, prefiriendo regular severamente su ejercicio, el modelo que describimos pone su energía en terminar con la prostitución y no simplemente regularla. He aquí la principal diferencia entre ambos. Así, la medida principal implementada por este modelo es la criminalización de la prostituta, a quien responsabiliza de la existencia misma de la prostitución; se la culpabiliza, sin considerar al cliente como responsable. ${ }^{45}$

A diferencia del abolicionismo primigenio, no ve a quienes ejercen la prostitución como víctimas o esclavas objeto de tutela, sino como delincuentes y principales responsables de este "mal social". Este modelo ve a la trabajadora sexual como principal infractora del orden moral y no conforme con el reproche social, criminaliza su desviación. ${ }^{46}$ En consecuencia, este modelo penaliza principalmente a la prostituta, pero también al proxeneta, al tercero locativo y a otros quienes de alguna manera se aprovechan del fenómeno. ${ }^{47}$ Quienes defienden este sistema abogan por que al Estado le corresponde garantizar y regular la moral pública para proteger el interés general. Además, señalan que si no se criminalizara sería interpretado por los ciudadanos como una tolerancia del Estado frente al vicio, por considerarse un mal necesario ${ }^{48}$. Este modelo es evidentemente conservador y puritano.

\subsection{Abolicionismo contemporáneo}

Las bases del neo abolicionismo, o abolicionismo contemporáneo, se sentaron en 1949 con el Convenio contra la trata de personas y la explotación de la prostitución ajena. Ese año el reglamentarismo fue derrotado oficialmente, instalándose este nuevo modelo en prácticamente todos los países. En él se señalaba que tanto la prostitución como la trata eran atentatorias contra la dignidad de la persona humana y ponían en peligro el bienestar del individuo, la familia y la comunidad. ${ }^{49}$ Este modelo se declaraba contrario a cualquier forma de reglamentación del ejercicio de la prostitución. Así, se cambiaba el discurso de la moralidad, transformándose en uno protector de la dignidad, con el que se protegía la intimidad de las prostitutas. La mira de este convenio estaba en el intermediario, el tercero que se favorecía de la prostitución ajena. No obstante, la línea abolicionista no se plasmaba en estas declaraciones, que más bien se asemejaban al prohibicionismo. Aquella se manifestaba en la consideración de quienes ejercían la prostitución como víctimas cuyo consentimiento era irrelevante y que, por ende, quedaban al margen de cualquier intervención penal. ${ }^{50}$

Este convenio desconocía el principio de la autonomía de la voluntad, imponiendo una censura moral a determinados comportamientos sexuales. Tenía además una línea proteccionista que veía a las personas que ejercían la prostitución como desviadas de

\footnotetext{
${ }^{45}$ VILLACAMPA, "Políticas de criminalización de la prostitución”, cit. nota $n^{\circ} 42$, p. 85.

${ }^{46}$ MAQUEDA, María Luisa, "La prostitución: el "pecado" de las mujeres", Cuadernos electrónicos de filosofía del derecho, n³5, 2017, pp. 64-89, p. 66.

${ }^{47}$ VILLACAMPA, "Políticas de criminalización de la prostitución”, cit. nota n 42 , p. 86.

${ }^{48}$ GARRIDO, La prostitución, cit. nota $\mathrm{n}^{\circ} 5$, pp. 57 y ss.

${ }^{49}$ Convenio para la represión de la trata de personas y de la explotación de la prostitución ajena, 1949. En: http://www.ohchr.org/SP/ProfessionalInterest/Pages/TrafficInPersons.aspx [visitado el 04.09.2017]., preámbulo.

50 “Convenio para la represión”, cit. nota $\mathrm{n}^{\circ} 49$, pp. 12 y ss.
} 
cierto orden, por cuanto establecía medidas de reinserción, prevención y rehabilitación. ${ }^{51}$ Luego, esta visión es profundizada tal como se observa del trabajo de las Reuniones Internacionales de Expertos sobre explotación sexual, celebradas en Madrid en 1986 y Pensilvania en $1991 .^{52}$ En ellas es negada cualquier posibilidad de prostitución voluntaria, siendo el patriarcado el principio organizador de esta. Señalan que el poder masculino divide a las mujeres en esposas y putas, siendo las primeras principalmente reproductoras, carentes de sexualidad y las segundas objeto del ejercicio de una sexualidad masculina carente de responsabilidad social. Plantean que es un verdadero desafío a la razón la venta, alquiler o alienación de la sexualidad, una función humana fundamental. ${ }^{53}$

Niegan el derecho a la prostitución, afirmando que sería contrario a la dignidad e integridad física y mental de quienes la ejercen. ${ }^{54}$ Además señalan que perjudica no solo a quienes la ejercen, sino también a quienes no lo hacen, ya que legitima la venta del cuerpo de cualquier mujer, afianzando la idea de que la mujer es un objeto. En consecuencia, se niegan todas las posibilidades de ejercicio libre de la prostitución, rechazando incluso su diferenciación de la prostitución forzada. El paso siguiente es indiscutiblemente uno: la criminalización del cliente, ya que él es quien viola los derechos humanos de quienes ejercen la prostitución. ${ }^{55}$ A menudo, el abolicionismo se ha servido de ideologías conservadoras, apareciendo casi siempre vinculado a la defensa de un determinado orden moral sexual colectivo. ${ }^{56}$

\subsection{Legalización}

Este modelo nace en la década de los 80 , junto con los reclamos de las organizaciones de prostitutas como sindicatos, en las que las voces de quienes ejercen la prostitución son plasmadas por primera vez en un modelo, sin intermediarios. ${ }^{57} \mathrm{El}$ feminismo liberal de corte igualitario se uniría a las demandas de las prostitutas, llegando a formar colectivos en conjunto. ${ }^{58}$ Es patente que en los modelos anteriores no participaban las prostitutas como actores pensantes. En ellos la prostituta es vista como un enemigo, delincuente promotora de la degradación moral, o bien, como víctima, esclava o incapaz, una persona que no puede hablar por sí misma, a quien es necesario liberar.

Si bien en base a una perspectiva liberal se pueden plantear diferentes modelos, tales como el no intervencionista o el regulacionista, ${ }^{59}$ nosotros nos referimos al modelo laboral, por ser este propiamente feminista, además de ser el actualmente antagónico al abolicionismo. Lo que pretende este modelo no es la mantención del orden público, la

\footnotetext{
51 “Convenio para la represión”, cit. nota n ${ }^{\circ} 49$, artículo 16.

52 “Convenio para la represión”, cit. nota ${ }^{\circ} 49$, p. 19.

53 “Convenio para la represión”, cit. nota ${ }^{\circ} 49$, pp.19 y ss.

${ }^{54}$ Latamente, CARMONA, Encarna, “¿Es la prostitución una vulneración de Derechos Fundamentales?”, en SERRA, Rosario (Coord.), Prostitución y Trata, Valencia: Editorial Tirant lo Blanch, 2007, pp. 43-70, passim

${ }^{55}$ Vid. infra 4.

${ }^{56}$ LAMAS, Marta, "Feminismo y prostitución: la persistencia de una amarga disputa", Debate Feminista, $\mathrm{n}^{\circ} 51,2016$, pp. 18-35, pp. 21 y 22.

${ }^{57}$ VILLACAMPA, "Políticas de criminalización de la prostitución”, cit. nota $n^{\circ} 42$, p. 86.

${ }^{58}$ Como el colectivo Hetaira en España, creado en defensa de los derechos de las trabajadoras del sexo. Para más información ver: http://www.colectivohetaira.org/WordPress/

${ }^{59}$ Sobre ellos, ampliamente MAQUEDA, "Prostitución, feminismos y derecho penal”, cit. nota ${ }^{\circ} 2$, pp. 81-91.
} 
habitabilidad de las ciudades, ni el control de las prostitutas, sino la consideración de esta actividad como trabajo, igual que cualquier otro. ${ }^{60}$ Este modelo clama por regulación, pero ya no la propugnada por el reglamentarismo, sino por derechos laborales y de seguridad social. Este modelo plantea un estatuto jurídico para las prostitutas, como cualquier otro trabajador, ${ }^{61}$ o persona que ejerce el comercio.

La decisión de ejercer la prostitución constituiría una expresión del derecho a la autodeterminación sexual, ampliamente reconocido en occidente, siempre y cuando hablemos de una relación entre adultos, en la que no tenga cabida la coacción, es decir libremente pactada. La negación de ese derecho sería en realidad una expresión de moralismo y discriminación, que tienen su causa en la indeseabilidad moral y social de la prostituta. Se ve la legalización como una forma de integración social de las trabajadoras sexuales, ya que afirma que la principal causa de su estigma es la marginación, que tendría una relación directa con la ilegalidad. La legalización significaría una normalización de esta actividad, lo que a la larga repercutiría en su aceptación social. Sobre este punto es ilustrativa Cristina Vasilescu, que a través de cuestionarios abiertos realizados a cuatro prostitutas derriba los mitos del abolicionismo. Ahí se constata que efectivamente viven una doble vida, sin embargo, ello se debe a que sienten que la gente ve su trabajo como desviado e inmoral, cuando ellas consideran que es como cualquier otro. ${ }^{62}$

Señalan que la decisión de ejercer la prostitución es una decisión libre y racional de adultos y que, por ende, debe ser respetada por el derecho. Se reivindica el derecho a decidir de las prostitutas, quienes no deben ser tratadas como víctimas o esclavas. La protección penal debe circunscribirse a los menores de edad y a la explotación realizada bajo coacción. ${ }^{63}$

\section{Feminismos y prostitución}

Cierto es que el feminismo posee diversas corrientes, muchas de las cuales tienen ideas divergentes y contrapuestas respecto de varios temas contingentes, como lo son la participación de los hombres en el feminismo, los vientres de alquiler y lo que nos compete, la prostitución. Las corrientes feministas son tan diversas como las concepciones de libertad e igualdad. Ellas incluso buscan objetivos diferentes entre sí. Entre ellas encontramos el eco feminismo, el feminismo socialista, ${ }^{64}$ el anarco feminismo, el feminismo negro, el feminismo de la diferencia, el feminismo de la igualdad, el lesbo feminismo, el feminismo cultural, etc. Sin embargo, nos centraremos en dos de sus corrientes más importantes: el feminismo liberal, y el feminismo radical.

\footnotetext{
${ }^{60}$ MAQUEDA, "Prostitución, feminismos y derecho penal”, cit. nota n 2, p. 91.

${ }^{61}$ VILLACAMPA, "Políticas de criminalización de la prostitución”, cit. nota ${ }^{\circ} 42$, p. 86.

${ }^{62}$ VASILESCU, Cristina, "Mitos y realidades entorno a la prostitución”, InDret, n³, 2017, pp. 1-26, pp. 16-17.

63 JAREÑO, Ángeles, "La política criminal en relación con la prostitución: ¿Abolicionismo Legalización?, en SERRA, Rosario (Coord.), Prostitución y Trata, Valencia: Editorial Tirant lo Blanch, 2007, pp. 71-86, p. 75.

${ }^{64}$ Destacan las feministas obreras, Flora Tristán, aunque de origen aristócrata, fue una de ellas. También pensadores marxistas como Engels, quien sostiene que la opresión femenina acabaría con su independencia económica. Alejandra Kollontai, sin embargo, fue quien dio un paso más allá del marxismo, defendiendo la autonomía sentimental y sexual de las mujeres, sentando así las bases para el feminismo radical. VARELA, Nuria, Feminismo para principiantes, España: Ediciones B, 2009, p. 61.
} 
Ya hemos hecho un recuento de la historia de la prostitución y de las diferentes formas de tratamiento que existen por parte del Estado. Los modelos que este trabajo busca abordar son principalmente dos, el abolicionismo y la legalización, ambos feministas tal como señalamos presentemente. Con respecto a la prostitución (y también a la pornografía), tradicionalmente se cree que el feminismo liberal está a favor de su legalización y en contra de efectuar un reproche moral y/o jurídico. Por su parte, se piensa que el feminismo radical está a favor de un reproche moral y de la abolición tanto de la prostitución como de la pornografía. Sin embargo, demostraremos que esto no está lógicamente ligado.

\subsection{Feminismo liberal}

El origen del feminismo liberal se remonta a los orígenes del feminismo en general, es decir a la primera ola feminista contemporánea a la Ilustración. ${ }^{65}$ En aquella época las ideas de libertad e igualdad solamente estarían referidas a los hombres, no habiendo un cambio significativo en la ideología respecto de las mujeres, ${ }^{66}$ en efecto, “(...) las francesas y todas las europeas salieron de aquella gran revuelta peor de lo que entraron". ${ }^{67}$ No obstante, las ideas de igualdad universal y racionalidad evidentemente encontrarían contradicción con las ideas patriarcales de sus pensadores. Las mujeres no serían pasivas espectadoras de la historia, ellas comenzarían a cuestionarse su exclusión de la ciudadanía. Pensadoras como Mary Wolstonecraft ${ }^{68}$ y Olimpia de Gouges serían las primeras mujeres en repugnar su posición de subordinación, abogando por igual acceso a la educación, divorcio y libertad de culto. Así, el feminismo radicalizaría las ideas de libertad e igualdad presentes en la Ilustración, llevando hasta último término sus pretensiones emancipatorias. ${ }^{69}$

Luego, estas ideas sentarían las bases para la segunda ola del feminismo en la cual el liberalismo y en particular el feminismo liberal tendrían un rol protagónico, su objetivo era conseguir el voto femenino. ${ }^{70}$ En Inglaterra se sentaron las bases para una nueva

\footnotetext{
${ }^{65}$ Aunque antes de la Ilustración existió feminismo, sin embargo, este no se cuestionaba la relación de poder entre hombres y mujeres. RICOY, Rosa, "Teorías jurídicas feministas", en: FABRA, Jorge Luis; NÚÑEZ, Álvaro (Coord.)Enciclopedia de filosofía del derecho y teoría jurídica, México: Universidad Autónoma de México, 2015, pp. 459-499, p. 469. En: https://biblio.juridicas.unam.mx/bjv/detallelibro/3875-enciclopedia-de-filosofia-y-teoria-del-derecho-volumen-uno [visitado el 20.10.2017].

${ }^{66}$ Filósofos tan influyentes como Kant, Hegel y Rousseau -entre muchos otros- defenderían la idea de la inferioridad natural de las mujeres, asimilándolas a niños. Sobre como igualitarismo y patriarcalismo pudieron convivir, ampliamente, PATEMAN, Carole, "Críticas feministas a la dicotomía público/privado", en: CASTELLS, Carme (Coord.), Perspectivas feministas en teoría política, Barcelona: Editorial Paidós, 1996, pp. 31-52, passim.

${ }^{67}$ VARELA, Feminismo para principiantes, cit. nota $n^{\circ} 64$, p. 21.

${ }^{68}$ La prostitución no fue un tema central para las feministas de esta época. Sin embargo, Mary Wollstonecrft relata en una de sus novelas las injusticias sufridas por las prostitutas: "No contentos con recibir de nosotras, proscritas de la sociedad, una gratificación brutal y gratuita (lo que otras mujeres llaman favores) como un privilegio de su cargo, cobraban un diezmo por la prostitución y hostigaban con amenazas a las pobres criaturas cuya ocupación no rentaba lo suficiente para silenciar sus gruñidos de avaricia”. WOLLSTONECRAFT, Mary, María, Colección Tras Latitudes, publicada en 1798. En: http://assets.espapdf.com/b/Mary\%20Wollstonecraft/Mary\%20-\%20Maria\%20-

\%20Mathilda\%20(5665)/Mary\%20-\%20Maria\%20-\%20Mathilda\%20-\%20Mary\%20Wollstonecraft.pdf [visitado el 10.10.2017], p. 539.

${ }^{69}$ Esta idea es desarrollada por AMORÓS, Celia: "El feminismo: senda no transitada de la ilustración", Isegoría, revista de filosofía moral y política, $\mathrm{n}^{\circ} 1,1990$, pp. 129-166, passim.

${ }^{70} \mathrm{Se}$ inaugura el sufragismo en Estados Unidos en el año 1848 con la Declaración de Seneca Falls, una reunión de mujeres y hombres convocada por Elizabeth Cady Stanton con el objeto de discutir los
} 
concepción de la libertad, de la igualdad e incluso del amor, todo esto de la mano de John Stuart Mill y la feminista Harriet Taylor, ${ }^{71}$ quienes juntos escribirían libros y construirían las bases teóricas del feminismo liberal y del sufragismo. Stuart Mill sería férreo defensor de los derechos de las mujeres en el parlamento, siendo él quien presentó la primera moción de voto femenino. ${ }^{72}$

El feminismo liberal de Taylor y Mill enfocó sus esfuerzos en derogar las estrictas normas que constreñían a las prostitutas, es decir en acabar con el modelo reglamentarista. Vemos aquí un primer matiz en la idea ampliamente extendida de que el feminismo liberal está ligado a la legalización de la prostitución. Podemos ver que en efecto, en sus orígenes al menos, estuvo ligado a la corriente contraria, es decir el abolicionismo, aunque debemos recordar que en ese entonces sus objetivos eran muy diferentes a los del abolicionismo contemporáneo.

Habiendo ya alcanzado el voto femenino y estando cada vez más cerca de la igualdad de derechos civiles y políticos, el enfoque del feminismo liberal giró hacia desigualdades más concretas. Se abre paso a la tercera ola del feminismo, y se constituye el feminismo liberal con una identidad propia y no simplemente como un apéndice del liberalismo. En un primer momento se caracteriza por definir la situación de las mujeres como una de desigualdad y no de opresión y, por ende, postula una serie de reformas principalmente legales en orden a alcanzar la igualdad de sexos. Para esta corriente el problema era eminentemente político y no sexual. Así, abogaría por la inclusión de las mujeres en el mercado laboral y su formación política en miras a alcanzar mayor representatividad, ${ }^{73}$ en general, su objetivo era la inclusión de las mujeres en la esfera pública.

Betty Friedan ${ }^{74}$ fue pionera en comenzar a escribir sobre este feminismo liberal con una identidad propia, su objetivo fue describir y conceptualizar "el problema sin nombre". En su libro "La Mística de la Feminidad", relata los problemas de las mujeres de clase media y bien educadas de los Estados Unidos. Estos problemas vinieron luego de la II Guerra Mundial, cuando sus esposos volvieron de la guerra y ocuparon los puestos de trabajo en que ellas estaban. A esto se sumaría el maltrato doméstico, la discriminación laboral, la dependencia de sus maridos, etc., cuestión que frustraría de sobremanera a las mujeres de la época, muchas de ellas universitarias. Se produjo un incremento de los ataques de pánico y las enfermedades sin explicación, sumado a un sentimiento profundo de vacío que las hacía sentirse como "electrodomésticos". Friedan puso la primera piedra para construir el colectivo de mujeres más grande que jamás ha conocido

derechos y la condición social, civil y religiosa de la mujer. VARELA, "Feminismo para principiantes", cit. nota $n^{\circ} 64$, p. 38.

${ }^{71}$ Mill escribió un libro sobre la emancipación femenina, respecto del cual se cree que Harriet Taylor tuvo mucha incidencia. MILL, John Stuart, La esclavitud femenina, Alicante: Fundación Biblioteca Virtual Miguel de Cervantes, 1999. En: http://www.cervantesvirtual.com/obra-visor/la-esclavitud-femenina-0/html/fefa4632-82b1-11df-acc7-002185ce6064.html [visitado el 10.09.2018].

${ }^{72}$ VARELA, Feminismo para principiantes, cit. nota ${ }^{\circ} 64$, pp. 46 y ss.

73 DE MIGUEL, Ana, "Feminismos", en: AMORÓS, Celia (Dir.), 10 palabras clave sobre Mujer,Pamplona: Editorial Verbo Divino, 1995, pp. 217-253, p. 269.

${ }^{74}$ Friedan fue una destacada psicóloga, alcanzando las notas más altas de su generación. Sin embargo, abandonaría su carrera para ser ama de casa. Además, también era brutalmente golpeada por su marido, incluso durante muchos años de su activismo feminista. Así, ella también sufría "el problema sin nombre". 
la historia, NOW, ${ }^{75}$ que tuvo y ha tenido múltiples objetivos, como la igualdad de oportunidades, la igualdad en cargos directivos, el fin de la discriminación laboral, etc. Aunque algunos han tendido a pensar que este movimiento necesariamente adopta una postura capitalista, lo cierto es que no es así. En la Mística de la Feminidad se señala que el capitalismo es precisamente el articulador del confinamiento de las mujeres en el hogar. $^{76}$

El feminismo liberal, al igual que el feminismo radical, es esencialmente un feminismo de la igualdad, puesto que rechaza una especificidad natural del sexo femenino en oposición al masculino, situando esta idea como el sustento de la jerarquía entre sexos. ${ }^{77}$ Sin embargo, esta postura sería criticada por no vislumbrar al patriarcado como un problema y por tener una visión liberal-formal, sin percatarse de que de nada servía la igualdad formal sin igualdad material, ${ }^{78}$ la lucha del feminismo liberal era por alcanzar el éxito y participación de las mujeres en la esfera pública, sin hacerse cargo de los problemas de la esfera privada. El feminismo liberal terminaría por aceptar estas críticas y finalmente adoptaría como propio el lema "lo personal es político", típicamente radical y, por ende, reconocería también los problemas propios de la esfera privada.

Una de las mejores representantes del feminismo liberal contemporáneo, que asume los problemas propios de la esfera privada es la filósofa norteamericana Martha Nussbaum. Ella incluso acepta algunas de las críticas provenientes del feminismo radical al liberalismo como teoría política, en particular, que no se ha hecho cargo de la necesidad de cuidado en momentos de extrema dependencia ni del rol político de la familia. ${ }^{79} \mathrm{Su}$ postura al respecto es que el liberalismo no debe ser descartado, sino que es necesario reestructurarlo de manera importante. ${ }^{80}$

Sus campos de estudio son variados, estando entre ellos el análisis de la pornografía, la prostitución y la cosificación, ${ }^{81}$ asumiendo y aceptando la idea de que existe un sistema de jerarquía entre los sexos. En el contexto actual, tanto cuando hablamos de esta filósofa como de otras pensadoras radicales, la prostitución, pornografía y cosificación ocupan un rol fundamental en el análisis y de cierta forma se hayan conectadas entre sí. Nussbaum es un ejemplo de que la concepción ampliamente extendida de que el feminismo liberal no haya nada incorrecto en la prostitución, pornografía y cosificación, es del todo errónea. En efecto, la filósofa analiza diversas clases de pornografía y representaciones eróticas a la luz del feminismo y algunas ideas de Kant, concluyendo que cierta clase de pornografía cosifica a las mujeres, representándolas como seres carentes de cualquier humanidad, sobre esto volveremos más adelante. Ella efectúa un reproche moral a la comercialización del sexo, a industrias como Playboy ${ }^{82}$ y la

\footnotetext{
75 National Organization for Woman u Organización Nacional para las Mujeres, cuya sigla en inglés significa "ahora".

${ }^{76}$ TRIMIÑO, Celina, “Aportaciones del feminismo liberal al desarrollo de los derechos políticos de las mujeres”, Tesis Doctoral, Universidad Carlos III de Madrid, Getafe, 2010.

${ }^{77}$ RICOY, "Teorías jurídicas feministas", cit. nota n 65, p. 482.

${ }^{78}$ LÓPEZ, Teresa, “Autonomía”, en: AMORÓS, Celia (Dir.), 10 palabras clave sobre Mujer, Pamplona: Editorial Verbo Divino, 1995, pp. 151-188, p. 175.

${ }^{79}$ NUSSBAUM, Martha, "El futuro del liberalismo feminista”,Areté, n 1, 2001, pp. 59-101.

${ }^{80}$ NUSSBAUM, "El futuro del liberalismo feminista”, cit., nota ${ }^{\circ} 79$, p. 65.

${ }^{81}$ NUSSBAUM, Martha: “Objectification”, Philosophy and Public Affairs, vol. 24, n4 1995, pp. 249291.

${ }^{82}$ NUSSBAUM, “Objectification”, cit. nota n 81 , pp. 283 y ss.
} 
pornografía hardcore. ${ }^{83}$ Pese a que no está a favor de ninguna clase de restricción legal, su análisis dista mucho de la caricaturización que se ha hecho sobre el feminismo liberal.

\subsection{Feminismo radical}

El feminismo radical surge en la tercera ola y sus fundamentos fueron propuestos por Simone de Beauvoir, quien con su libro "El segundo sexo" dio nuevos bríos al feminismo. Con su frase "no se nace mujer, se llega a serlo", además de muchas otras construcciones filosóficas e interdisciplinarias, problematizó la construcción de la sociedad que concebía a la mujer como "la otra" respecto del hombre, ${ }^{84}$ poniendo sobre la palestra pública temas no resueltos aun hoy. Para Beauvoir la prostitución no era muy diferente a la institución del matrimonio.

Con las obras de Kate Millet, "Política Sexual" y Sulamith Firestone, "La Dialéctica del Sexo", entre otras, surgen nuevos conceptos que serán fundamentales para el feminismo. Uno de ellos es el "patriarcado", que se refiere a un sistema de dominación femenina o bien un complejo de supremacía masculina, ${ }^{85}$ en el que se asientan el resto de los sistemas de dominación como el de raza o clase. Otro de los conceptos introducidos por estas feministas es el "género" que hace referencia a la construcción social (expectativas sociales) sobre el sexo. A diferencia del feminismo liberal, esta corriente puso especial énfasis en la sexualidad y en la esfera privada. Se dedicaron a analizar el entramado de poder que estructuraba la familia y la sexualidad, criticaron el estereotipo del cuerpo femenino y la representación de la mujer como un objeto sexual. Ellas contribuyeron a desligar la sexualidad de la procreación, afirmaron su derecho al placer y negaron la maternidad obligatoria. Consiguieron así la despenalización de los métodos anticonceptivos y en muchos casos del aborto. ${ }^{86}$ Para estas radicales, la idea de peligro convivía con la de placer en la sexualidad y la revolución sexual era compatible con la emancipación femenina. Estas feministas, consideraban que las relaciones de poder no estaban constituidas por algo natural, ellas provenían de los roles de género impuestos y aprendidos en el proceso de socialización. Los hombres solo eran enemigos en la medida que no cuestionaran y se identificaran con su rol de supremacía, ${ }^{87}$ así, el feminismo radical también es una forma de feminismo de la igualdad.

Una de las principales pensadoras radicales contemporáneas es la inglesa Carole Pateman, para ella el liberalismo tiene un carácter patriarcal desde sus orígenes, el contrato social afirmaría la libertad de los hombres, pero también la sujeción de las mujeres. Este pacto estaría basado en un contrato previo, uno sexual y ambos son el medio a través del cual el patriarcado se constituye. ${ }^{88}$ Pateman dirige sus críticas hacia la separación de la esfera pública y la esfera privada, separación que relega a las mujeres al ámbito privado, otorga libertad a los hombres para desenvolverse en sus hogares de una forma que atenta contra la liberad de las mujeres, e ignora el rol público

\footnotetext{
${ }^{83}$ NUSSBAUM, “Objectification”, cit. nota n ${ }^{\circ} 81$, pp. 279 y ss.

${ }^{84}$ VARELA: "Feminismo para principiantes", cit. nota ${ }^{\circ} 64$, pp. 68 y ss.

${ }^{85}$ PULEO, Alicia, "Patriarcado", en: AMORÓS, Celia (Dir.), 10 palabras clave sobre Mujer, Pamplona: Editorial Verbo Divino, 1995, pp. 21-54.

${ }^{86}$ VARELA, Feminismo para principiantes, cit. nota ${ }^{\circ} 64$, pp. 87 y ss.

${ }^{87}$ MAQUEDA, Prostitución, feminismos y derecho penal, cit., nota n²4, pp. 16 y 17.

${ }^{88}$ PATEMAN, Carole, El contrato sexual, Barcelona: Editorial Antrophos, 1995, especialmente pp. $11 \mathrm{y}$ ss.
} 
y político que tiene la familia. ${ }^{89}$ Las mujeres no habrían sido parte de este pacto social inicial, sino objeto de un contrato sexual mediante el cual los hombres se distribuyen el acceso a las mujeres. Es decir, el liberalismo como teoría política basada en un el contrato social sería fruto de un árbol envenenado, incapaz de crear una sociedad equitativa para las mujeres. La sola existencia de esta esfera privada, en la que el Estado no puede adentrarse, asegura a los hombres el dominio sobre las mujeres; a su vez, la esfera pública ha sido creada por y para los hombres y en consecuencia es y será ajena a las mujeres.

Pateman explica que la prostitución ${ }^{90}$ sería uno de los contratos que se enmarcan dentro del contrato sexual que asegura a los hombres el acceso al cuerpo de las mujeres (el matrimonio sería la contracara de la misma moneda). En la lógica contractualista que Pateman critica, la prostitución sería simplemente un servicio pactado entre particulares, en virtud de la libertad contractual y la igualdad de oportunidades. Sin embargo, el liberalismo no tendría perspectiva histórica sobre el contrato sexual, por ejemplo, no repara en el hecho de que la mayoría de quienes se prostituyen son mujeres -muy pocos hombres heterosexuales lo hacen-, lo cual no es casual, sino que tiene relevancia política. Cuando se mira el contrato sexual de forma crítica, "[e]1 problema de la prostitución entonces, aparece encapsulado en la cuestión de por qué los varones exigen que las mujeres vendan sus cuerpos como bienes en el mercado capitalista. La historia del contrato sexual también ofrece la respuesta: la prostitución es parte del ejercicio de la ley del derecho sexual masculino, uno de los modos en que los varones se aseguran el acceso al cuerpo de las mujeres". 91

Catharine MacKinnon es también una influyente feminista radical, ${ }^{92}$ que ha propulsado políticas de erradicación de la pornografía y la prostitución en Estados Unidos. Al igual que Pateman, tiene una visión sistémica e histórica de la jerarquía entre los $\operatorname{sexos}^{93}$ y critica al liberalismo por ser incapaz de ofrecer respuestas certeras a las mujeres. ${ }^{94}$ Catharine MacKinnon, en su libro Feminismo Inmodificado plantea que es necesario tener en cuenta que existe un sistema que otorga poder a los hombres sobre las mujeres, quienes han sido educadas para encajar en un determinado rol sexual. El género es una categoría jerárquica, de poder, que se expresa en el sexo. La sexualidad y por ende las violaciones, el coito o la pornografía, han sido vistas desde la perspectiva masculina, teniéndola por objetiva. Se ha pasado por alto la perspectiva de las mujeres sobre estos temas y cuando se ha tenido en cuenta, se le ha tildado de "subjetiva". Considera fundamental ver las cosas desde el punto de vista femenino, a modo de ejemplo, conceptualiza la violación como "toda ocasión en que una mujer tiene sexo y se siente

\footnotetext{
${ }^{89}$ PATEMAN: “Críticas feministas a la dicotomía público/privado", cit. nota ${ }^{\circ} 66$, en especial pp. 20 y ss.

${ }^{90}$ PATEMAN: El contrato sexual, cit. nota ${ }^{\circ} 88$, se refiere ampliamente a la prostitución en sus páginas 260 y ss.

${ }^{91}$ PATEMAN, El contrato sexual, cit. nota n88, p. 267.

92 Algunas como Maqueda han insinuado que en realidad es una feminista cultural, ya que a sus ojos describen la sexualidad masculina como naturalmente violenta, sin embargo, MacKinnon expresamente señala que la jerarquía entre los sexos es una construcción social. En consecuencia las apreciaciones de Maqueda no son acertadas. MAQUEDA, “Prostitución, feminismos y derecho penal”, cit. nota n².

93 Debemos tener en cuenta que esto no se predica exclusivamente de las feministas radicales, ya que, como hemos señalado precedentemente, liberales como Nussbaum también la tienen.

94 Por ejemplo, MACKINNON, Catharine, Feminismo inmodificado, Argentina: Editorial Siglo Veintiuno, 2014, p. 35.
} 
violada". ${ }^{95}$ Esto no con fines legales sino políticos, busca que las mujeres nos preguntemos “¿Me sentí violada?”; 96 y a su vez, preguntarle a los hombres; “¿Alguna vez han tenido sexo con una mujer cuando ella no quería hacerlo? ¿Han sido y son realmente cuidosos para averiguarlo?". 97

MacKinnon afirma que la prostitución es una violación a los derechos civiles de las mujeres e incluso a su humanidad, no importa como la concibamos. ${ }^{98}$ Las prostitutas son degradas, torturadas, repetidamente violadas en un trato cruel e inhumano. Para esta autora, la prostitución no puede ser ejercida de forma libre, puesto que se enmarca en la dominación y subordinación y así lo demuestra la experiencia. ${ }^{99}$ Ella establece una relación entre la prostitución y la pornografía, puesto que la pornografía incrementa la violencia contra las prostitutas y en realidad daña a todas las mujeres, ${ }^{100}$ sobre esto volveremos más adelante.

No obstante, también podemos ver que dentro del feminismo radical hay pensadoras muy distantes de estos postulados, una de ellas es Gayle Rubin. Para ella el sexo es político y tiene sus propios juegos de poder y opresión, la lucha contra la prostitución en realidad sería parte del pánico sexual, puesto que la prostitución sería inocua. ${ }^{101}$ En la misma línea, está Virginie Despentes, una feminista radical francesa que en su libro "La Teoría King Kong" nos relata su experiencia como prostituta. Ella critica a las feministas que propugnan por la abolición de la prostitución, considera que su discurso las hace ver como mujeres siempre víctimas, incapaces, de quienes debemos compadecernos, lo cual no puede estar más alejado de su experiencia.

\section{3. ¿Está realmente conectado el feminismo liberal con la legalización y el radical con la abolición?}

Frecuentemente se ha asumido por algunas pensadoras feministas ${ }^{102}$ que el feminismo liberal estaría ligado indisolublemente a la legalización por estimar que existe libertad contractual de los particulares, para pactar servicios sexuales, situación en la cual el estado no puede inmiscuirse por estar dentro de su esfera privada. También se ha asumido que el feminismo radical estaría lógicamente conectado con la postura a favor de la abolición, ya que al estimar que existe un sistema patriarcal que subordina a las mujeres, entienden que la prostitución no puede ser ejercida de otra forma que no sea la dominación. Sin embargo, esta suposición no parece correcta.

En primer lugar, tanto el feminismo radical como el feminismo liberal son feminismos de la igualdad, lo que quiere decir que ambos estiman que las diferencias sociales entre los sexos no son naturales ni consecuencia de ninguna característica intrínseca de los

\footnotetext{
${ }^{95}$ MACKINNON, Feminismo inmodificado, cit., nota ${ }^{\circ}$ 94, p. 123.

${ }^{96}$ MACKINNON, Feminismo inmodificado, cit., nota ${ }^{\circ}$ 94, p. 123.

${ }^{97}$ MACKINNON, Feminismo inmodificado, cit., nota ${ }^{\circ}$ 94, p. 124.

98 MACKINNON, Catharine, "Prostitution and Civil Rights", Michigan Journal of Gender and -law, vol.1, nº1, 1993, p 13 .

${ }^{99}$ MACKINNON, "Prostitution and Civil Rights", cit. nota ${ }^{\circ}$ 98, p. 24.

${ }^{100}$ MACKINNON, "Prostitution and Civil Rights", cit., nota ${ }^{\circ}$ 98, p. 30.

101 RUBIN, Gayl, "Reflexionando sobre el sexo: notas para una teoría radical de la sexualidad", en: VANCE, Carole (Comp.), Placer y peligro, explorando la sexualidad femenina, Madrid: Editorial Revolución, 1989, pp. 113-190.

${ }^{102}$ Así por ejemplo, VILLACAMPA, Carolina, "Políticas de criminalización de la prostitución" cit. nota n42 y; MAQUEDA, María Luisa, “Prostitución, feminismos y derecho penal”, cit. nota n 2 .
} 
sexos, sino construcciones socio-culturales sobre los roles de género. Esto en oposición a otros feminismos como el cultural (el cual es un feminismo de la diferencia) que considera relevantes las diferencias naturales y sexuales entre ambos sexos y por ende si podría estar lógicamente ligado a una postura abolicionista al estimar que la sexualidad masculina es siempre represora. Sin embargo, al ser el feminismo radical, uno de la igualdad, se abre paso a la pregunta de si la sexualidad masculina e incluso la prostitución pueden ser ejercidas de una forma respetuosa a los derechos y deseos de las mujeres.

Prueba de que el feminismo radical no se halla lógicamente ligado al abolicionismo, es que algunas feministas radicales como Virginie Despentes o Gayle Rubin, están a favor de la legalización. Para cierto sector del feminismo radical la opresión a las mujeres es también una represión de su sexualidad, de sus deseos legítimos y de cualquier forma de expresión erótica. Estiman que la prostitución y la pornografía pueden resultar, en efecto, liberadoras para las mujeres y que propugnar por su abolición es un nuevo discurso puritano y moralista.

¿Cuál es entonces la diferencia entre el feminismo liberal y el feminismo radical? Por un lado feminismo liberal estima como acertada la división entre la esfera pública y privada. Considera que el liberalismo puede dar una respuesta satisfactoria a los problemas de las mujeres, siendo necesaria quizás su reforma, ${ }^{103}$ así su objetivo sería la universalización de los principios y valores liberales. Por su parte, el feminismo radical critica esta división, señalando que lo que sustenta al contrato social es un contrato sexual mediante el cual se afirma el dominio de los hombres sobre las mujeres. ${ }^{104}$ Estiman al liberalismo como insuficiente, como un obstáculo en el avance de los derechos de las mujeres, ${ }^{105}$ él sería intrínsecamente patriarcal.

Cuando la argumentación del feminismo liberal se centra en la libertad contractual y en que la prostitución acontece en la esfera privada de las personas y que por ende el Estado no puede entrometerse, evidentemente está ligado a la postura a favor de la legalización. Pero la argumentación del feminismo liberal es bastante más compleja que esto y el análisis que hace Nussbaum es un claro ejemplo de ello. La filósofa identifica la complejidad del entramado patriarcal y de hecho critica ciertas formas de pornografía por cosificar a las mujeres, fortalecer el patriarcado y fomentar una forma de masculinidad violenta. Ella considera que en ocasiones la pornografía (e insinúa que la prostitución también) es moralmente reprochable y pese a que no está de acuerdo con efectuar un reproche jurídico, su argumento no tiene que ver con la intromisión a la esfera privada, sino con el derecho a la libertad de expresión y la no censura de ciertos discursos. También debemos recordar que los liberales Taylor y Mill eran abolicionistas. Esto demuestra que, en efecto, el feminismo liberal tampoco está intrínsecamente ligado a la postura a favor de la legalización y del rechazo al reproche moral a la prostitución.

Por todo esto, considero que es posible pensar en la propuesta de un modelo que sea transversal a un feminismo liberal cuyos argumentos no se agoten en la no intromisión de la vida privada; y a un feminismo radical que también considere que el placer y la sexualidad de las mujeres ha sido reprimida y ocultada como parte del sistema

\footnotetext{
${ }^{103}$ NUSSBAUM, "El futuro del liberalismo feminista", cit. nota n ${ }^{\circ} 79$, p. 65.

${ }^{104}$ Idea ampliamente desarrollada por PATEMAN: El contrato sexual, cit. nota n ${ }^{\circ} 88$.

${ }^{105}$ MACKINNON, Feminismo inmodificado, cit. nota n ${ }^{\circ} 94$, p. 33 y ss.
} 
patriarcal. ¿Qué caracterizaría a una propuesta feminista?, esto en comparación a otras propuestas e independientemente del feminismo del que hablemos. En primer lugar debe carecer de cualquier consideración a los roles de género y en consecuencia, cuestionar y tender a eliminar la distinción entre "buenas" y "malas" mujeres, teniendo a su vez en consideración que el sexo tiene para las mujeres una doble dimensión de placer y de peligro. En segundo lugar, debe alejarse del discurso de la obscenidad y en su lugar, ocuparse de acabar con la subordinación femenina. ${ }^{106}$ Por último, cuando hablamos de prostitución debe centrarse en el protituidor y no en la prostituta, puesto que gracias a que él demanda prostitución es que ella existe; y en consecuencia debe tender a hacerle cargar a él y no a la prostituta con las consecuencias negativas de la prostitución, mientras que otorga derechos a quienes se prostituyen.

\section{Balance ¿Abolicionismo o legalización?}

Ya que el objetivo de la presente investigación es resolver en clave feminista la pregunta sobre si es necesario castigar, confrontaremos los argumentos de las dos principales propuestas feministas, es decir, el abolicionismo y la legalización. Tomaremos como base la propuesta abolicionista puesto que propugna por limitar la libertad de las personas, en tanto la postura de la legalización propugna por otorgar derechos y por ende contraargumenta los postulados del abolicionismo. Es necesario destacar que la división de estos argumentos no es tan sistemática como la propondremos. Esta forma de exponer las cosas ha sido utilizada para efectos de clarificar un discurso que se presenta algo confuso. En efecto, unos y otros argumentos tienen estrechas conexiones entre sí.

\subsection{Primer argumento: La prostitución es una práctica intrínsecamente degradante, incompatible con la dignidad y con el respeto de los derechos fundamentales de la persona}

Según esta postura, relacionar la prostitución con la libertad sexual es olvidar que la sexualidad como actividad humana requiere de una relación de igualdad y voluntariedad, una expresión de libertad compartida y en la que no puede caber la relación comercial, que constituye en sí misma una situación de abuso, de poder. La sexualidad formaría parte de un aspecto íntimo de nuestra personalidad, que exige ser disfrutado libremente y no como una forma de ganar dinero. ${ }^{107}$

Además, de acuerdo con este planteamiento la prostitución supone vulnerar Derechos Fundamentales, lo cual estaría avalado por estadísticas. Las prostitutas sufrirían problemas en su salud física, tales como heridas, enfermedades de transmisión sexual (presentes en un $80 \%$ de ellas), mayores probabilidades de tener cáncer al útero, etc. Todo esto además de problemas en su salud psíquica, como estrés post traumático, depresión, ansiedad y trastornos disociativos. ${ }^{108}$ La prostitución sería per se contraria a la dignidad humana, lo que estaría estrechamente vinculado con el postulado de que su práctica cosifica a quien la ejerce, de ahí que se la criminalice.

\footnotetext{
${ }^{106}$ MACKINNON, Feminismo inmodificado, cit. nota n ${ }^{\circ}$ 94, p. 211 y ss.

${ }^{107}$ CARMONA, “¿Es la prostitución una vulneración de Derechos Fundamentales?”, cit. nota n 54, p. 65.

108 ORENGO, F: "Simposio Internacional sobre Prostitución y Tráfico de Mujeres con Fines de Explotación Sexual”, citado por CARMONA, “Es la prostitución una vulneración de Derechos Fundamentales?", cit., nota ${ }^{\circ}$ 54, p. 67.
} 
La postula a favor de la legalización responde a esta idea criticándola, por considerar que la criminalización (aunque sea del cliente), implica mayores vulneraciones de los Derechos Fundamentales de la prostituta. La legalización en cambio, supondría una mejora en la independencia y seguridad de las trabajadoras sexuales, otorgándoles los mismos derechos laborales que a otros trabajadores. ${ }^{109}$

Además, la idea de que la prostitución es una actividad dañina, en realidad correspondería a una manifestación más del pánico moral. La invención de supuestas víctimas se usaría como un medio para criminalizar lo que se considera un "vicio". Así, se criminaliza una gama de conductas inocuas tales como el consumo recreativo de drogas, la obscenidad, la prostitución o incluso la homosexualidad, en pro de la salud y seguridad de las personas. E inclusive cuando la actividad se asume como no perjudicial, es criminalizada de todas maneras, arguyendo que da origen a un mal mucho mayor. ${ }^{110}$ En el caso de la prostitución, el mal mayor al que supuestamente da origen, es la trata de personas con fines de explotación sexual. ${ }^{111}$

\subsection{Segundo argumento: Quien ejerce la prostitución es cosificado y mercantilizado}

En esta línea, Lagarde afirma que por definición quienes ejercen la prostitución no son personas autónomas, sino que un cuerpo objeto para el placer de otros, en otras palabras, su cuerpo subjetivo, su persona, está cosificada y no hay un "yo" en el centro. Según su visión, en esta situación no hay posibilidad de construir una persona que se autodefine, que se autolimita, que se protege y se desarrolla a sí misma. ${ }^{112}$ Como complemento a esto, se ha planteado por esta clase de feminismo, que la prostitución implica la venta del cuerpo o la reducción de personas a mercancías. Así por ejemplo, Carmona compara la prostitución con un contrato de esclavitud y con la venta de órganos, no estableciendo entre ellos diferencia alguna. ${ }^{113}$ En el mismo sentido, Mathieu habla de alquilar el cuerpo para uso sexual. ${ }^{114}$

Sin embargo, el hecho de que la relación se realice con un precio de por medio no es relevante para efectos de la cosificación, ya que ella podría presentarse en relaciones sexuales ocasionales e incluso en relaciones de pareja estables o matrimonios. La cosificación en un sentido fuerte implica utilizar a alguien sola y exclusivamente como instrumento, y en un sentido débil, implica ignorar el conjunto de aspiraciones y deseos de otra persona. ${ }^{115} \mathrm{Si}$ bien es cierto que los servicios sexuales son mejor ocasión para la cosificación sexual en un sentido fuerte, nada obstaría a que ella se produzca en otras circunstancias, y lo cierto es que nadie trata de penalizar la promiscuidad, por ejemplo.

\footnotetext{
${ }^{109}$ LAMAS, “Feminismo y prostitución”, cit. nota $\mathrm{n}^{\circ} 56$, p. 25.

${ }^{110}$ RUBIN: "Reflexionando sobre el sexo", cit., nota ${ }^{\circ} 101$, p. 40.

${ }^{111}$ En el caso de las drogas frecuentemente se sostiene que, de legalizarlas, se produciría un incremento de los otros delitos.

${ }^{112}$ LAGARDE, Marcela, “Claves feministas para el poderio y autonomía de las mujeres”, Nicaragua: Puntos de Encuentro, 1997, p. 55.

${ }^{113}$ CARMONA, “¿Es la prostitución una vulneración de Derechos Fundamentales?”, cit., nota n54, pp. 64 y 65.

114 MATHIEU, Lilian, "Las causas económicas de la prostitución”, en: Aún creemos en los sueños (ed.) La prostitución. Debate sobre el derecho a vender el cuerpo: causas de la prostitución; redes internacionales mafiosas; la prostitución infantil, etc., Santiago: Aún creemos en los Sueños., 2004, p 23. ${ }^{115}$ BELTRÁN, Elena, "En los Márgenes del Derecho Antidiscriminatorio: Prostitución y Derechos de las Mujeres”, Anales de la cátedra Francisco Suarez n45, 2011, pp. 43-63.
} 
En cuanto a la mercantilización del cuerpo, creemos que existe cierta confusión, puesto que si bien es cierto que se comercia con la función sexual, ello no implica la "venta del cuerpo". Aunque es necesario introducir ciertos matices, ${ }^{116}$ todos en realidad comerciamos con nuestra corporalidad o sus funciones y cuando lo hacemos, no por ello enajenamos nuestro organismo. Así, un académico comercia con su función intelectual $\mathrm{y}$ un boxeador comercia con su fuerza.

\subsection{Tercer argumento: La prostituta ha de tener la condición de víctima}

De la mano de lo anterior, viene la consideración de las prostitutas como víctimas, ya que dicha actividad es explicada, a juicio de quienes piden abolición, como producto de patologías, pobreza, muestra de debilidad psíquica o inmadurez. Quienes ejercen la prostitución vendrían de los sectores desposeídos o incluso marginales de la sociedad. ${ }^{117}$ Ellas presentarían bajos niveles de escolaridad, condiciones de vida precarias y serían agredidas con una frecuencia alarmante. ${ }^{118}$ Además, se señala que un porcentaje importante de quienes la ejercen habrían sufrido abusos sexuales en la infancia, lo que llevaría a una predisposición para el ejercicio del comercio sexual. ${ }^{119}$

El trabajo sexual admite matices y si bien es cierto que en muchas ocasiones quienes lo realizan lo hacen por necesidad económica, no es menos cierto que este en ocasiones representa para ellas el menor de los males. ${ }^{120}$ En el mismo sentido, se señala que lo realmente preocupante es que existan mujeres pobres que no tienen más opciones laborales. En ese sentido, la crítica feminista debiera estar orientada a la ampliación de las oportunidades de educación, capacitación y a la creación de nuevos empleos. ${ }^{121} \mathrm{El}$ discurso que tilda a las mujeres de víctimas les resta capacidad de decisión, apoderándose de la definición de lo que es una conducta sexual adecuada. ${ }^{122}$

\subsection{Cuarto argumento: La prostitución es un problema de género, las prostitutas son mujeres y los prostituidores son hombres que afirman su derecho al cuerpo femenino}

Se plantea que la inmensa mayoría de quienes ejercen la prostitución son mujeres y que los clientes son hombres, que llama protituidores. En el caso de los colectivos trans que la ejercen, ellos también lo hacen al servicio del deseo masculino. Por alguna razón los hombres encontrarían placer en mantener relaciones con alguien que se encuentra en una posición de inferioridad, que no siente deseo por ellos y que incluso, algunas veces siente rechazo. ${ }^{123}$

Las mujeres, en términos casi absolutos, no serían consumidoras de prostitución. Tal como señala De Miguel, "[e]l rechazo de la prostitución masculina por parte de las mujeres no radica en su falta de poder o dinero sino en que no encuentran placer en tener relaciones sexuales con quienes se encuentran en una situación de clara

\footnotetext{
${ }^{116}$ Vid. infra 6.2.1.

${ }^{117}$ MATHIEU, "Las causas económicas de la prostitución”, cit. nota n 114, p. 23.

${ }^{118}$ MATHIEU, "Las causas económicas de la prostitución”, cit. nota n 114, p. 23.

${ }^{119}$ CARMONA, “ES la prostitución una vulneración de Derechos Fundamentales?”, cit., nota $\mathrm{n}^{\circ} 54$, pp. 63 y 64.

${ }^{120}$ LAMAS, “Feminismo y prostitución”, cit. nota $\mathrm{n}^{\circ} 56$, p. 24.

${ }^{121}$ LAMAS, “Feminismo y prostitución”, cit. nota $\mathrm{n}^{\circ}$ 56, p. 25.

${ }^{122}$ LAMAS, “Feminismo y prostitución”, cit., nota ${ }^{\circ} 56$, p. 26.

123 DE MIGUEL, Ana, "La prostitución de mujeres, una escuela de desigualdad humana", Revista Europea de Derechos Fundamentales, na19, 2012, pp. 49-74, pp. 10 y ss.
} 
inferioridad -semidesnudos en fila, en los parques, polígonos y burdeles- y, además, no las desean en absoluto. (...) Detenerse a pensar en los fundamentos de rechazo de las féminas arroja luz sobre la particularidad del comportamiento de los hombres que encuentran placer en disponer de mujeres prostituidas. Parece que uno de los núcleos del placer que experimentan reside en entrar en relaciones físicas definidas por su situación de poder y falta de reciprocidad". ${ }^{124}$

Así, se propone una definición alternativa de prostitución que dé cuenta de esta situación, "la prostitución es una práctica por la que los varones se garantizan el acceso grupal y reglado al cuerpo de las mujeres". ${ }^{125}$ El varón tendría derecho a satisfacer su deseo sexual, sin importar las consecuencias y sin ser considerado como responsable de ellas. "Si las familias de los países más desolados por la desigualdad y el sexismo venden a sus hijas, ése no es el problema de los clientes. Si las chicas han sido traficadas desde Somalia o Etiopía, no es ése el problema de los clientes. Ellas no son sujetos, son los objetos, las mercancías expuestas para que el comprador, el cliente, elija, pague y se corra". ${ }^{126}$ En consecuencia, se propone penalizar al cliente como primordial sostenedor del fenómeno.

Independiente de que el argumento de que la prostitución es un problema de género, la criminalización está lejos de ser la solución para las prostitutas. Este planteamiento busca el fortalecimiento del sistema penal, sin embargo, la excesiva intromisión del Derecho Penal en problemas sociales termina por perjudicar a quienes padecen las injusticias. En efecto, como señala Larrauri “(...) el derecho penal de los oprimidos está condenado a ser (sólo) simbólico ya que éstos carecen de la fuerza para imponerse en el sistema que aplica las normas". ${ }^{127}$ En cuanto a los triunfos punitivos del feminismo, estos terminaron empeorando la situación de las mujeres, esto debido a que el rol simbólico no necesariamente se cumple debido a la falta de publicidad. Súmese el hecho de que, al conseguir una conquista legal, viene una sensación de victoria que termina desmovilizando a los grupos feministas. ${ }^{128}$

Se critica también el discurso victimista para designar a sujetos cuya situación es producto del sistema neoliberal y de la violencia estructural. Al abogar por aumentar el Poder Punitivo, el abolicionismo estaría siendo funcional al sistema neoliberal carcelario. La sexualidad masculina es percibida como una amenaza, de la cual el Estado y la policía nos salvarían, promoviendo de paso el fortalecimiento de un sistema patriarcal de Estado, que ve a las mujeres como víctimas que requieren ser protegidas, ${ }^{129}$ es decir, la criminalización fomenta y profundiza los roles de género y la subordinación de las mujeres.

\subsection{Quinto argumento: La prostitución no es un trabajo}

Para los defensores de esta postura, la prostitución no es un trabajo como cualquier otro, ya que solo puede analizarse desde un prisma que tenga en cuenta el patriarcado, es decir, considerando la histórica subordinación de las mujeres. Así, ella constituye una

\footnotetext{
${ }^{124}$ DE MIGUEL, "La prostitución de mujeres", cit. nota ${ }^{\circ} 123$, pp. 10 y ss.

${ }^{125}$ DE MIGUEL, "La prostitución de mujeres", cit. nota ${ }^{\circ} 123$, p. 16.

${ }^{126}$ DE MIGUEL, "La prostitución de mujeres", cit. nota n 123, p. 16.

${ }^{127}$ LARRAURI, Elena, La herencia de la criminología crítica, Madrid: Editorial Siglo XXI, 2000, p 223.

${ }^{128}$ LARRAURI, La herencia de la criminología crítica, cit. nota ${ }^{\circ} 127$, p. 222.

${ }^{129}$ LAMAS, Feminismo y prostitución, cit. nota ${ }^{\circ} 56$, pp. 27 y 28.
} 
relación de dominación que es imposible denominar "trabajo". ${ }^{130}$ Cuando la actividad sexual se convierte en un medio de subsistencia, la personalidad y el desarrollo humano de la persona se ven seriamente afectados. ${ }^{131}$

Por el contrario, quienes abogan por legalizar la prostitución hacen notar que genera ingresos a la las mujeres que la desempeñan. Esto sería razón suficiente para el reconocimiento de esta actividad como trabajo, ya que no hacerlo significa la exclusión de los derechos y una ciudadanía plena. Las feministas habrían conseguido que el trabajo doméstico, el cuidado de ancianos y la crianza de los hijos fueran catalogados como trabajo, actividades que bajo esta lógica, no deberían ser diferenciadas de la prostitución. ${ }^{132}$ Arguyen que la prostitución es un trabajo como cualquier otro, en cuya elección confluyen factores como las necesidades económicas u otros factores personales, sin que por ello deje de ser una actividad laboral. Para quienes piden la legalización, es necesario regular esta actividad, otorgando a las prostitutas derechos sociales y laborales. Esto requiere que sus opiniones sean escuchadas y plasmadas en las leyes. ${ }^{133}$

\subsection{Sexto argumento: La prostitución afecta incluso a las mujeres que no se prostituyen}

De acuerdo con este argumento, la prostitución aporta en la construcción del imaginario de lo que es una mujer y qué se puede hacer con ella. Ella muchas veces representa una "escuela" en la que los hombres jóvenes aprenden lo que es el sexo, lo cual implica que interiorizarán que el único placer importante es el propio. Esto se traduce en que no tendrán ningún conocimiento sobre sexualidad femenina, lo que en último término repercute en la sexualidad de cualquier mujer. Súmese a esto que la prostitución constituye una relación de poder sobre todas las mujeres, es una restauración simbólica de la dominación masculina. Esto trae consecuencias negativas para la reciprocidad en todas sus relaciones y en una supuesta concepción igualitaria de las personas. ${ }^{134}$ Este fenómeno supone el renacimiento de ciertas concepciones patriarcales. Por un lado, estarían las mujeres madres y esposas, respetables, buenas mujeres, las cuales podrían limitar el acceso a su cuerpo; y, por otro lado, estarían las mujeres públicas, las malas mujeres, que carecen de ese derecho. Se plantea que, aunque esto sea negado alegando el consentimiento de la prostituta, la verdad es que la mayoría de ellas no pueden elegir a sus clientes. ${ }^{135}$

Llega incluso a estimarse a las prostitutas como "traidoras del género", al ejercer su actividad al margen de estas críticas. Se considera, además, que su rol es funcional a los intereses del patriarcado. Maqueda apoyada en Osborne sostiene que esta calificación fue formulada “(...) quizás queriendo ocultar que el orden patriarcal necesita para su subsistencia también de las no prostitutas, que la división entre malas y buenas mujeres

\footnotetext{
${ }^{130}$ DE MIGUEL, "La prostitución de mujeres”, cit. nota ${ }^{\circ} 123$, p. 15.

${ }^{131}$ CARMONA, “¿Es la prostitución una vulneración de Derechos Fundamentales?”, cit. nota n 54, p. 65.

132 MESTRE, Ruth, "Trabajo, igualdad y reconocimiento de derechos”, en: CERRA, Rosario, Prostitución y Trata, Valencia: Editorial Tirant lo Blanch, 2007, pp. 13-42, p. 32.

133 GARAIZÁBAL, Cristina, “Una mirada feminista a la prostitución”, 2007. En: www.colectivohetairas.org [visitado el 28.08.2018], p. 3.

${ }^{134}$ DE MIGUEL, "La prostitución de mujeres", cit. nota $n^{\circ} 123$, pp. 19 y ss.

${ }^{135}$ DE MIGUEL, "La prostitución de mujeres", cit. nota ${ }^{\circ} 123$, pp. 21 y ss.
} 
forma parte esencial de la cultura patriarcal y sirve a los fines de control socio sexual de todas, gracias al poder de definición del estigma que se asocia a las primeras". ${ }^{136}$

La criminalización no sirve al objetivo de acabar con la distinción entre buenas o malas mujeres, lo realmente útil para cuestionar esta idea es la lucha contra el estigma que padecen las prostitutas, ${ }^{137}$ estigma que es favorecido por el abolicionismo. Cierto es que, en realidad, son las prostitutas quienes desprecian el orden sexual establecido, ya que no cumplen con el ideal de castidad y recato. ${ }^{138}$ Cuando el abolicionismo las culpa de ello, imputándoles una afrenta contra todas las mujeres, en realidad está aceptando ese orden sexual como propio. La idea de que las prostitutas son malas mujeres y el estigma que pesa sobre ellas también opera sobre todas las mujeres disuadiéndolas de traspasar los límites de lo permitido. ${ }^{139}$

4.7. Séptimo argumento: El tratamiento de la prostitución no puede ni debe desligarse del tratamiento de la trata de mujeres y menores y de la explotación sexual, porque ésta sigue siendo la gran realidad que se esconde tras de ella

Este planteamiento afirma que en algunas sociedades las mujeres que prestan su consentimiento para una relación sexual remunerada no son suficientes para satisfacer la demanda de servicios sexuales por parte de los hombres. Esto, en último término haría que los traficantes sustraigan mujeres de otros países para cubrir la demanda. ${ }^{140}$ En este contexto, el castigo al cliente tendría un rol especial de disuasión, que repercutiría en los incentivos del proxeneta para traficar mujeres. Por todo esto, el abolicionismo serviría supuestamente para disminuir la trata de mujeres.

Sin embargo, esta discusión evade la cuestión básica, a saber, el concepto de prostitución y trata del que se parte. Se habla generalizadamente de víctimas sin distinguir si lo son de abuso, engaño, coacción o bien del dominio u opresión estructurales de un sistema capitalista y patriarcal. ${ }^{141}$ Esto, junto con la negación de la libertad y la victimización siempre y en todos los casos, implica la prohibición de cada uno de los comportamientos relacionados con el trabajo sexual. Lo anterior acarrea que, tal como en el caso de los delitos vinculados con el tráfico de drogas, se favorece el comercio negro y clandestino, que obtiene mejores beneficios mientras mayor sea la prohibición.

Quienes abogan por la legalización están de acuerdo con que el tráfico de personas para fines de explotación sexual bajo coacción o amenaza es un delito terrible. Sin embargo, difieren en cuento a la magnitud y origen del problema. Añaden que las cifras que existen al respecto son confusas, ya que los parámetros de caracterización de las víctimas son ambiguos. Los discursos abolicionistas sobre la trata en realidad serían exagerados, magnificando el problema y añadiendo detalles especialmente mórbidos. ${ }^{142}$

\footnotetext{
${ }^{136}$ MAQUEDA, Prostitución, feminismos y derecho penal, cit. nota $\mathrm{n}^{\circ}$ 4, p. 29.

${ }^{137}$ GARAIZÁBAL, "Una mirada feminista a la prostitución”, cit. nota n`133, p. 1.

${ }^{138}$ LAMAS, “Feminismo y prostitución”, cit. nota ${ }^{\circ} 56$, p. 26.

${ }^{139}$ GARAIZÁBAL, “Una mirada feminista a la prostitución”, cit. nota n¹33, p. 2.

${ }^{140}$ CARMONA, “¿Es la prostitución una vulneración de Derechos Fundamentales?”, cit. nota n54, p. 66.

${ }^{141}$ MAQUEDA, Prostitución, feminismos y derecho penal, cit. nota ${ }^{\circ} 4$, p. 31.

${ }^{142}$ LAMAS, “Feminismo y prostitución”, cit. nota ${ }^{\circ}$ 56, pp. 23 y 24.
} 
Se señala además que creer que la prostitución inevitablemente favorece la trata es parte de un discurso de pánico moral por la pérdida de cierto orden y valores. Es una expresión del pánico social, ya que es absolutista, escabroso y exagerado. ${ }^{143}$ Este discurso alarmista, estaría caracterizado por ser conservador e irracional. Así, en algunos países como Estados Unidos la lucha legítima contra la trata, ha terminado en fuertes intervenciones policiales, reprimiendo a todas las personas involucradas en el comercio sexual con el pretexto de la búsqueda de "victimas". Incluso se han creado sistemas de incentivos para los policías que rescaten más "víctimas". ${ }^{144}$

Bajo estos términos, no es de extrañar que prostitución y trata se confundan cuando quienes prestan los servicios son inmigrantes. En relación con esta problemática, es común que existan prejuicios en torno al fenómeno de la migración para el comercio sexual, debido a que las migrantes generalmente provienen de países tercermundistas. En palabras de Mestre: "(...) el argumento abolicionista parece decir que las mujeres occidentales elegimos porque estamos en posición de hacerlo, mientras que el resto de las mujeres del mundo no eligen porque no están capacitas o en posición de hacerlo". ${ }^{145}$ A la vulnerabilidad del género, manifestada en "inocencia y sumisión", se asocian otras desvalorizaciones provenientes de la etnia, al caracterizarlas como "atrasadas e ignorantes" o de las condiciones económicas "pobres y sin recursos". 146

Se confunde así la prostitución y la trata cuando quienes la ejercen son extranjeras. El abolicionismo supone que estas extranjeras serían pobres y carentes de formación. En consecuencia, asume que en la mayoría de los casos quienes migran a un país para ejercer la prostitución, lo hacen en condiciones de coacción o engaño o, en cualquier caso, carentes de libertad.

\subsection{Conclusión a la que llega el abolicionismo: negación de la distinción entre prostitución libre y forzada}

En atención a los tópicos anteriores, este planteamiento se ubica en la cúspide del abolicionismo. Tal como hemos visto, creen que la prostitución es atentatoria de la dignidad, supresora de la personalidad y de los derechos humanos. Por todo esto, plantean que es imposible que ella sea ejercida de forma libre. Esta premisa ha sido formulada en términos absolutos, postulando que la mujer que ejerce la prostitución siempre es una víctima que merece protección de hombres violentos.

Los abolicionistas aseguran que incluso si existe consentimiento este no es suficiente argumento para legalizar la prostitución, ya que no por el mero hecho de que exista consentimiento cualquier contrato será válido. En ese orden de ideas, consideran que es una actividad dañina y contraria a los valores imperantes en nuestras sociedades democráticas y que, al igual que otros contratos como la esclavitud o la venta de sangre, adolecen de objeto ilícito, por considerarse "extra comercium". Es más, la sociedad

\footnotetext{
${ }^{143}$ LAMAS, “Feminismo y prostitución”, cit. nota $n^{\circ} 56$, pp. 23 y 24. Absolutista en la medida que la caracterización del problema no admite matices; escabroso, ya que describe con detalles los casos más terribles; y exagerado ya que infla la cantidad de víctimas y el daño social ocasionado.

${ }^{144}$ LAMAS, “Feminismo y prostitución”, cit. nota ${ }^{\circ} 56$, p. 24.

${ }^{145}$ MESTRE, "Trabajo, igualdad y reconocimiento de derechos”, cit. nota ${ }^{\circ} 132$, p. 32.

${ }^{146}$ MAQUEDA, "Prostitución, feminismos y derecho penal”, cit. nota ${ }^{\circ} 2$, p. 30 .
} 
limita ciertos contratos que, aunque fueran voluntarios, son contrarios a los valores de igualdad, por ejemplo, la poligamia. ${ }^{147}$

Sin embargo, existen ciertos grupos disidentes feministas y prostitutas que reivindican el derecho de estas a decidir, así como su autonomía y libertad. Quienes claman por la legalización señalan que la realidad de las mujeres que se prostituyen es tan amplia y diversa, que lo que existe es un continuum de relativa libertad y relativa coerción. ${ }^{148}$ Las prostitutas serían de diferentes clases sociales, diferentes grados de formación, etc. Por ende, para algunas la elección puede resultar liberadora y empoderante, ${ }^{149}$ mientras que para otras puede causar culpa y vergüenza. ${ }^{150}$

En consecuencia, esta opción parece menospreciar el poder de decisión de quienes la ejercen, constituyéndose estas circunstancias en una presunción de involuntariedad. Obviando además que en nuestra sociedad casi nadie elige libremente su trabajo, ya que todos en alguna medida nos vemos influidos por nuestras circunstancias. Maqueda afirma que el discurso victimista se apropia de su dignidad, llegando a señalar incluso que no tienen opinión debido a sus condiciones. ${ }^{151}$

Esto es lo que Rubin llama: "la teoría del lavado de cerebro", ${ }^{152}$ ya que hay ciertos actos sexuales que algunos consideran tan desagradables que nadie podría acceder a realizarlos. ${ }^{153}$ En este caso se presentaría un absolutismo de los propios valores y creencias, revestido de un falso empirismo, puesto que una creencia personal de lo que una persona haría en su sano juicio se extrapola como premisa universal. Señalan que la experiencia sexual se vive individual y socialmente de maneras muy diversas. Los sujetos se encuentran en "mapas" políticos y sociales complejos, al mismo tiempo que concurren factores como la edad, que hacen que esta no sea una experiencia universalizable. ${ }^{154}$

En cuanto al argumento de que las sociedades limitan la celebración de contratos, debido a que hay bienes extra comercium, nos parece discutible. Esto, ya que esta categoría ha sido variable en el tiempo y entre culturas. El caso de la venta de sangre es un buen ejemplo de ello. En países como Estados Unidos ella es legal y está regulada e incluso se permite la venta de óvulos y espermatozoides. Por otro lado, lo que se negocia en la prostitución no es un bien, sino la realización de un servicio, es una obligación de hacer y no de dar y en consecuencia no parece lógico el afirmar que los genitales son bienes extra comercium puesto que el objeto del contrato es la realización de una actividad y no los mismos genitales.

\section{Una propuesta feminista. Entre lo moral y lo jurídico}

En este punto hemos de tener en cuenta ciertos prismas de análisis a la hora de adoptar uno u otro modelo. El primero es que es necesario tener una perspectiva del sistema

\footnotetext{
${ }^{147}$ DE MIGUEL, "La prostitución de mujeres", cit. nota ${ }^{\circ} 123$, p. 15.

${ }^{148}$ LAMAS, “Feminismo y prostitución”, cit. nota $n^{\circ} 56$, pp. 24 y 25.

${ }^{149}$ Como de hecho lo fue para, DESPENTES, Teoría King Kong, cit. nota ${ }^{\circ} 1$.

${ }^{150}$ LAMAS, “Feminismo y prostitución”, cit. nota ${ }^{\circ}$ 56, pp. 24 y 25.

${ }^{151}$ MAQUEDA, Prostitución, feminismos y derecho pena”, cit. nota ${ }^{\circ}$ 2, p. 27.

${ }^{152}$ RUBIN, "Reflexionando sobre el sexo", cit. nota n 101, p. 52.

${ }_{153}$ Rubin afirma esto en referencia a las disidencias sexuales dentro de las cuales incluye la prostitución.

${ }^{154}$ MESTRE, “Trabajo, igualdad y reconocimiento de derechos”, cit. nota ${ }^{\circ} 132$, p. 32.
} 
patriarcal, tanto en cuando oculta la sexualidad y reprime los deseos femeninos, como en cuanto a que gran parte de la dominación patriarcal es la violencia sexual (el sexo tiene una dimensión de placer y otra de peligro). El segundo es que muchos de los argumentos esgrimidos son efectivamente argumentos morales sobre cuál es la forma correcta de relacionarse, sobre todo sexualmente, con otros. El tercero es que la discusión en realidad versa sobre la necesidad de criminalizar al cliente, y por ende es una discusión de política criminal, de leyes que eventualmente limitan los derechos de las personas.

En este capítulo responderemos algunas preguntas necesarias para la propuesta de un modelo, en particular ¿es la prostitución siempre y en todos los casos reprochable moralmente? Y si lo es, o al menos lo es en algunos casos ¿en cuáles casos debe intervenir el Estado? ¿Cuándo una conducta sexual inmoral debería convertirse en una conducta punible?

Parece del todo necesario responder a estas preguntas si queremos llegar a una conclusión carente de prejuicios y en donde las posturas sean realmente clarificadas. Hemos de recalcar que gran parte de los argumentos que se plantean a favor de la criminalización son argumentos de carácter ético, argumentos sobre cómo las cosas deberían ser, sobre qué es necesario hacer para respetar la humanidad de las mujeres. En consecuencia, parece fundamental tomar una postura moral al respecto. Súmese el hecho de que antes de responder la pregunta sobre la criminalización es necesario clarificar en primer lugar si hay algo "malo" en la prostitución, ya que nos parece que una condición mínima (aunque no suficiente) para criminalizar una conducta es que ella sea éticamente reprochable. La respuesta a ambas preguntas se efectuará teniendo en cuenta la existencia de un sistema de jerarquía entre los sexos y será, en consecuencia, feminista.

\section{1. ¿Es la prostitución siempre y en todos los casos contraria a la moral?}

La importancia de develar si la prostitución es o no una práctica intrínsecamente inmoral no es una puramente intelectual, sino que también práctica. En ese orden de ideas, hemos de recordar que la Constitución de 1980 prohíbe las asociaciones contrarias a la moral, ${ }^{155}$ así como también, acorde con nuestro Código Civil, la promesa de dar algo a cambio de un hecho inmoral adolece de causa ilícita. ${ }^{156}$ En consecuencia, la postura que adoptemos con respecto a la moralidad de la prostitución tiene consecuencias directas en el tratamiento estatal que se le otorgue. De este modo, si consideramos que la prostitución es efectivamente inmoral, el modelo de la legalización no tendría asidero en Chile por ser inconstitucional.

Los análisis éticos que han efectuado las feministas sobre el sexo, en general tienen como base tanto la prostitución como la pornografía, ya que ambas tienen varias cosas en común. Por ende, el desarrollo de este capítulo tendrá en cuenta también a la

\footnotetext{
${ }^{155}$ Artículo $19 \mathrm{n}^{\circ} 15$ inciso 4: "Prohíbanse las asociaciones contrarias a la moral, al orden público y a la seguridad del Estado." Constitución Política de la República, 2018. Disponible en: https://www.leychile.cl/Navegar?idNorma $=242302$

${ }^{156}$ Artículo 1467 inciso 3: "Así la promesa de dar algo en pago de una deuda que no existe, carece de causa; y la promesa de dar algo en recompensa de un crimen o de un hecho inmoral, tiene una causa ilícita." Código Civil, 2018. En: https://www.leychile.cl/Navegar?idNorma=172986 [visitado el 01.09.2018].
} 
pornografía, cuestionándonos si las conclusiones respecto de ella pueden ser aplicadas también a la prostitución.

\subsubsection{La visión de Kant}

La respuesta a la pregunta relativa a si la prostitución es (siempre) inmoral supone una pregunta previa, a saber, ¿cuál es la forma éticamente correcta de comportarse sexualmente? La primera intuición nos lleva a recurrir a Kant. La formulación de su mandato moral: "obra de tal modo que uses la humanidad, tanto en tu persona como en la persona de cualquier otro, siempre como un fin al mismo tiempo y nunca solamente como un medio"157 parece ser un aporte a la respuesta a esta pregunta. En materia sexual, podría sugerir que una conducta reprochable sería tratar a nuestra compañera o compañero como un simple medio o herramienta para conseguir placer. Esto, entendiendo que la sexualidad no está exenta de un ejercicio racional y que, de hecho, la toma de decisiones y el ejercicio de la autonomía parecen ser parte inherente de la sexualidad en nuestra especie, en contradicción con otras que actúan meramente por instinto.

A contrario sensu, una conducta sexual moralmente aceptable sería una en que se trate a la compañera o compañero como un ser humano, como un fin en sí mismo. Teniendo en cuenta sus propios deseos, sentimientos y experiencias. Lo que no excluiría el hecho de que se le trate como un medio para nuestro placer, ya que la premisa kantiana prohíbe hacerlo cuando se le trata sólo y únicamente como medio.

Sin embargo, Kant parece no ver las cosas de esta manera. Él de hecho aplica su teoría a la sexualidad en su libro "Lecciones de ética", en donde señala que el sexo per se convierte a quienes interactúan en cosas, humillando al Hombre y desvaneciéndose en él todos los móviles de las relaciones morales. Dice que es el único caso en que el Hombre se ve determinado por naturaleza a ser objeto del placer de otro, agregando que esto degrada la condición humana. Señala que la inclinación que un varón tiene hacia la mujer no considera a esta como una persona, sino que le resulta indiferente su condición de ser humano y solo atiende a su órgano sexual como objeto de su inclinación. ${ }^{158}$ "Cada hombre y cada mujer se esfuerzan por estimular en este terreno no su condición de ser humano sino únicamente su sexo, (...) [1]a condición humana es sacrificada en aras del sexo"159 -como si el estimular la sexualidad fuera contradictorio con estimular la humanidad-. Concluye que en este acto subyace algo despreciable que se opone a la moralidad. ${ }^{160}$

Evidentemente, si para Kant el sexo sin más supone un atentado a la moral, la prostitución en sus propias palabras es "la mayor depravación imaginable"161, señalando que es una venta del propio cuerpo. No obstante, para Kant hay una forma moralmente aceptable de ejercer la sexualidad, que es dentro de los límites del matrimonio monógamo, ya que en él ambas partes entregan al otro toda su persona y cobran derechos sobre la persona íntegra de él. En el matrimonio se otorga al otro la totalidad de la persona y no solo el sexo, no habiendo así, disociación. No otorga razones

\footnotetext{
${ }^{157}$ KANT: Fundamentación, cit. nota ${ }^{\circ} 28$, p. 84.

${ }^{158}$ KANT, Immanuel: Lecciones de ética, Barcelona: Editorial Crítica, 1988, pp. 203 y ss.

${ }^{159}$ KANT, Lecciones de ética, cit. nota ${ }^{\circ} 158$, p. 204.

${ }^{160}$ KANT, Lecciones de ética, cit. nota $\mathrm{n}^{\circ} 158$, p. 204

${ }^{161}$ KANT, Lecciones de ética, cit. nota ${ }^{\circ} 158$, p. 206.
} 
satisfactorias del por qué la institución del matrimonio asegura que al otro o a la otra no se le trate únicamente como un medio. A nuestro modo de ver, su sugerencia de que en él se produce una enajenación de la persona completa a favor de otro u otra, solo complica aún más el panorama moral. Ya que más que salvar la falta de moralidad intrínseca del sexo, nos llevaría consecuencialmente a cuestionar la moralidad de la institución misma del matrimonio. Esto porque tal como Kant señala, ni el cuerpo ni la persona pueden ser apropiables, son fines en sí mismos.

Pero volviendo al problema que ocupa nuestra atención, parece que Kant ignora el hecho que la humanidad incluye la sexualidad como parte de sus elementos, tal como podrían ser la afectividad o el intelecto. Sería ilógico pensar en que el ejercicio de la afectividad, separadamente de otros atributos, pueda degradar la humanidad de una persona, al contrario, pareciera ser que ese ejercicio la lleva a realizarse. Lo mismo puede predicarse respecto de la sexualidad, ya que en determinadas condiciones morales - que aún no dilucidamos- ella sería una expresión de humanidad. Súmese a esto que, en realidad, difícilmente podría decirse que los atributos de la condición humana son disociables, parece, al contrario que están interrelacionados entre sí, así por ejemplo, en la sexualidad la racionalidad y la afectividad también juegan un rol.

Ya que Kant no da una respuesta satisfactoria a nuestra pregunta $-\mathrm{o}$ al menos no una feminista- dirijamos nuestra atención entonces hacia los feminismos.

\subsubsection{La propuesta de MacKinnon}

Un primer acercamiento feminista a la respuesta a estas preguntas viene desde el feminismo radical, de mano de Catharine MacKinnon. Es necesario aclarar que su análisis no tiene por objetivo ser propiamente ético, sino político. Ello, claro está, no descarta las implicaciones éticas de su trabajo.

Tal como señalábamos precedentemente, Catharine MacKinnon tiene en cuenta que existe un sistema de poder sobre las mujeres y esto sería determinante en la construcción de su identidad sexual e incluso de sus deseos. En este contexto la autora se cuestiona si realmente existe un erotismo propio y respetuoso de las mujeres. Introduce como elementos fundamentales las percepciones, sentires, experiencias y perspectivas de las mujeres respecto del sexo, siendo este uno de los elementos relevantes en nuestro análisis ético. ${ }^{162}$ En cuanto a la pornografía, opina que erotiza la degradación femenina, promoviendo la libertad de expresión y sexual de los hombres y esclavizando a las mujeres. ${ }^{163}$ La pornografía sería la base y afirmación del sistema de supremacía masculina, la esencia del orden social sexista. ${ }^{164}$ Señala que las mujeres que participan de la pornografía no lo hacen libremente, carecen de opciones, de poder y muchas veces son pobres. ${ }^{165}$

MacKinnon califica la pornografía como deshumanizadora en un sentido específico y empíricamente descriptivo y enfatiza en que no es uno moralmente liberal. Su análisis es sistémico y práctico, no abstracto. Para ella la pornografía despoja a las mujeres del poder de definición sexual y se lo otorga a los hombres. Critica la visión kantiana en

\footnotetext{
${ }^{162}$ MACKINNON, Feminismo inmodificado, cit. nota ${ }^{\circ}$ 94, p. 122 y ss.

${ }^{163}$ MACKINNON, Feminismo inmodificado, cit. nota n ${ }^{\circ} 94$, p. 188.

${ }^{164}$ MACKINNON, Feminismo inmodificado, cit. nota ${ }^{\circ} 94$, p. 229.

${ }^{165}$ MACKINNON, Feminismo inmodificado, cit. nota n ${ }^{\circ}$ 94, p. 196 y ss.
} 
cuanto asigna un rol primordial a la libertad y racionalidad en la toma de decisiones, derechos que las mujeres no tendríamos. En la pornografía el fin de las mujeres sería el placer masculino. ${ }^{166}$ Estas ideas se condicen con lo que más adelante conceptualizaremos como denegación de autonomía (y autodeterminación), instrumentalidad y quizás, en algún sentido, apropiabilidad.

Pareciera que esta crítica que se hace al imperativo kantiano solo tiene validez en lo que respecta a la cosificación de uno mismo. Es decir, no podría aplicarse reproche moral sobre una mujer que participa de la pornografía o se prostituye si ella no posee los derechos o circunstancias materiales que la habilitan para elegir libre y racionalmente. No obstante, nada impide seguir implementando el imperativo moral de Kant sobre los prostituidores o pornógrafos, pues ellos sí tendrían libertad y racionalidad para decidir cómo actuar moralmente respecto de estas mujeres.

Mackinnon en conjunto con otra feminista radical, Andera Dworkin, propusieron ordenanza para limitar la pornografía. En ella definen la pornografía como "la subordinación gráfica, sexualmente explícita de las mujeres a través de imágenes o palabras, lo que también incluye mujeres deshumanizadas como objetos sexuales, cosas o mercaderías (...)". ${ }^{167}$ Incluyen así la noción de mujeres como objeto sexual, equivalente a la cosificación u objetivización.

\subsubsection{El análisis de Nussbaum}

Nussbaum, esta vez de mano del feminismo liberal y con un análisis propiamente ético práctico, en su artículo "Objectification" estudia y detalla el alcance del término cosificación. En él describe siete formas de cosificar a alguien, es decir, tratarle como objeto $^{168}$ :

- Instrumentalización: El cosificador trata al objeto como una herramienta para sus propósitos.

- Negación de autonomía: Se trata al objeto como carente de autonomía y autodeterminación.

- Inercia: Se trata al objeto como carente de agencia y quizás también de actividad.

- Fungibilidad: Se trata al objeto como intercambiable con otros objetos del mismo y/o de otros tipos.

- Violabilidad: Se trata al objeto como carente de límites de integridad, como algo que está permitido romper, aplastar o forzar.

- Apropiabilidad: Se trata al objeto como algo que le pertenece a otro, que puede ser comprado o vendido.

- Negación de subjetividad: Se trata al objeto como algo cuyas experiencias y sentires (si es que hay), no necesitan ser tomados en cuenta.

Para Nussbaum cosificar sería tratar a alguien, a un ser humano, de alguna de estas formas en las que se trata a los objetos. Solo basta una de estas formas para cosificar a alguien, lo que no significa que de ello siempre se desprenda un reproche moral. Argumenta en un primer momento que la negación de autonomía y negación de

\footnotetext{
${ }^{166}$ MACKINNON, Feminismo inmodificado, cit. nota ${ }^{\circ}$ 94, p. 236.

${ }^{167}$ MACKINNON, Feminismo inmodificado, cit. nota $n^{\circ}$ 94, p. 262.

${ }^{168}$ NUSSBAUM, “Objectification”, cit. nota n81, p. 257.
} 
subjetividad serían especialmente relevantes, puesto que no tiene sentido hablar de ellas con respecto a las cosas, que en ningún caso tienen autonomía o subjetividad. Estarían situadas, en cambio, en un contexto de tratamiento humano. ${ }^{169}$

Señala que para tratar a alguien como autónomo es necesario tratarle como no instrumental, no simplemente inerte, no apropiable, y como algo cuyos sentires importan. No obstante, tratar a alguien como autónomo es compatible con tratarle como fungible, es decir como intercambiable con otros agentes autónomos y también como violable, por ejemplo, en el sadomasoquismo consentido. ${ }^{170}$ Pareciera que hay aquí una inconsistencia en el análisis de Nussbaum, puesto que es perfectamente posible tratar a alguien como autónomo y a la vez como una herramienta para los propósitos de otro. En efecto, constantemente nos relacionamos con nuestros pares de esta forma, por ejemplo, si le pido a mi pareja que arme un mueble nuevo, teniendo presente que podría decirme que no. Es evidente que en cierta manera le estoy tratando como herramienta, pero a la vez reconociendo su autonomía. En este sentido, creo que la definición inicial que Nussbaum da de instrumentalización (que no incluye la palabra "solo"), se condice con la noción kantiana de tratar a alguien como medio. Pero hemos de recordar que el reproche moral acontece cuando tratamos a alguien únicamente como medio. Si bien el análisis de la filósofa parece un poco ambiguo en cuanto a la instrumentalización, luego, reconoce esta idea, al decir que la instrumentalización no es problemática per se, sino que lo es tratar a alguien primordialmente o meramente como un instrumento ${ }^{171}$. Es aquí donde surge la pregunta ¿En el sexo, cómo podemos tratar a alguien sólo como medio? O más bien, ¿cómo podemos no hacerlo?

Antes de responder esta pregunta, volvamos a la autonomía. Nussbaum señala que la negación de autonomía, por otro lado, no implica necesariamente tratar a alguien como inerte, violable o negar su subjetividad. Así, por ejemplo, si tuviéramos un esclavo, ciertamente negamos su autonomía, pero no lo vemos como inerte, ya que su trabajo es lo que nos interesa. No necesariamente es violable, ya que incluso podría haber leyes en contra de la violación o castigos físicos a esclavos; o bien, su integridad podría ser útil en el cumplimiento de sus tareas. Tampoco es necesaria la negación de su subjetividad, ya que podría existir cierta empatía hacia su dolor o sufrimiento. Por otro lado, tampoco implica apropiabilidad, fungibilidad o instrumentalización, como sucede respecto de un niño pequeño al que no se le reconoce autonomía.

Es decir, el análisis de la autonomía se hace en dos planos, su reconocimiento y su negación. Podemos ver en él que la autonomía es diferenciable de todas las otras categorías de cosificación.

Hasta aquí resultan especialmente relevantes las categorías de instrumentalización, que consideramos equivalente a tratar a alguien como medio, y las de autonomía y subjetividad, puesto que únicamente pueden predicarse de los humanos. En este punto la filósofa analiza la propuesta kantiana de ética sexual, afirmando que en ella subyace la idea de que el deseo es una fuerza tan poderosa que conduce a tratar a otros como cosas. Señala que esta idea de instrumentalización está estrechamente ligada con la de denegación de autonomía y subjetividad, visión según la cual, el agente las negaría para

\footnotetext{
${ }^{169}$ NUSSBAUM, “Objectification”, cit. nota n ${ }^{\circ} 1$, pp. 258 y 259.

${ }^{170}$ NUSSBAUM, “Objectification”, cit. nota n॰81, pp. 259 y ss.

${ }^{171}$ NUSSBAUM, “Objectification”, cit. nota n81, p. 265.
} 
asegurar su propio placer. ${ }^{172}$ En el sexo, para Kant, se anula toda posibilidad de considerar el placer del otro, lo que siempre y en todos los casos significaría un tratamiento del compañero o compañera meramente como instrumento, ${ }^{173}$ puesto que, insistimos, no habría otra opción más que tratarle como carente de autonomía y subjetividad. Por supuesto que Kant no incluye nociones feministas en su análisis y piensa que esta es una característica de la sexualidad en general y no de la sexualidad masculina, ya que no considera que el sexo está permeado por la jerarquía. ${ }^{174}$ Kant obvia el hecho de que la personalidad, humanidad e individualidad también residen en la sexualidad e incluso en los genitales. En efecto, la visión de Kant sobre el sexo parece deshumanizante, toda vez que ignora el importante rol de la sexualidad en la personalidad de los seres humanos.

Nussbaum concluye que tratar a otro como instrumento siempre es problemático si no se realiza en un contexto de profundo respeto por la humanidad, y esta es la forma central de cosificación que resulta moralmente reprochable. Señala que está íntimamente ligada con la negación de autonomía y de subjetividad, además de varias formas de negación de integridad; y algunas veces también está ligada con las nociones de fungibilidad y apropiabilidad. Sin embargo, ninguna de las formas de cosificación aparte de la instrumentalización- parece ser reprochable por sí sola en todos los casos.

Creo que este es un inicio de respuesta a la primera pregunta de este capítulo, pero me parece que otra vez, la división entre tratar a alguien como instrumento y tratar a alguien sólo como instrumento no es del todo clara. La instrumentalización, como la misma filósofa señala, no es moralmente reprochable per se y, por ende, pese a que es un elemento central del análisis, ciertamente no basta. Súmese el hecho de que no se establece en su artículo cuándo se trata a alguien solo como medio, como carente de humanidad, ya que para ella el resto de las formas de cosificación pueden o no concurrir. Luego, nos preguntamos, ¿existe alguna forma en que esta instrumentalización, acompañada de otra forma de cosificación siempre sea reprochable?

Debemos tener en cuenta que no parece posible el sexo sin instrumentalizar a otro, es decir, sin tratarle como un medio para conseguir nuestro propio placer. El análisis de Nussbaum se centra en las formas de representación eróticas o pornográficas de las mujeres y no en el plano de una relación real entre las personas, como lo es la prostitución. Esto puede tornar ambigua la respuesta a nuestra pregunta, que se haya en el plano del contacto corporal humano y no en el de las representaciones. Y, por ende, conclusiones como que la negación de autonomía o de subjetividad no son siempre moralmente reprochables, ${ }^{175}$ sólo son aplicables a las representaciones y no a las relaciones reales.

En cuanto a lo que a nosotros respecta, es imposible imaginar un solo caso en que la instrumentalización acompañada de negación de la autonomía, negación de la subjetividad o de apropiabilidad pueda ser moralmente aceptable cuando hablamos de la cosificación que una persona efectúa sobre otra y no sobre sí misma en el marco de una relación sexual con contacto corporal. Por otro lado, el tratamiento instrumental de una

\footnotetext{
${ }^{172}$ NUSSBAUM, “Objectification”, cit. nota n81, p. 266.

${ }^{173}$ NUSSBAUM, "Objectification”, cit. nota n॰81, p. 267.

${ }^{174}$ NUSSBAUM, “Objectification”, cit. nota n'81, p. 267.

${ }^{175}$ NUSSBAUM, “Objectification”, cit. nota ${ }^{\circ} 81$, p. 290.
} 
persona, siempre y cuando se reconozca su autonomía y, por tanto, se niegue su apropiabilidad y se le reconozca subjetividad (recordando el análisis de Nussbaum), puede ser compatible con cualquier otra forma de cosificación como la violabilidad y fungibilidad. Contrario al pensamiento de la filósofa, sostenemos que también es posible que el reconocimiento de autonomía sea compatible con la inercia al menos durante un periodo de tiempo acotado. Puesto que es dable pensar, por ejemplo, en una pareja en la que el hombre decide atarse y permanecer inerte por propia voluntad, sin desplegar actividad alguna.

En conclusión, la forma éticamente correcta de comportarse en cuanto al sexo, sería una que obedezca a un imperativo como el que sigue: aunque uses a tu compañero o compañera como instrumento de tu placer, siempre debes reconocerle la capacidad de autodeterminarse (lo que es contrario a su apropiabilidad) y respetar sus deseos, sensaciones y experiencias. Esta respuesta hace permisibles la violabilidad, al menos en un sentido que no amenace la existencia o el desarrollo normal de la persona; también sería permisible la fungibilidad y la inercia por un periodo acotado de tiempo.

\subsubsection{La prostitución y la experiencia de Despentes}

Ya habiendo esclarecido un parámetro ético de comportamiento sexual, hemos de preguntarnos si es posible que este se cumpla en la prostitución ¿es posible que el prostituidor respete la autonomía y subjetividad de las prostitutas? O ¿por el simple hecho de mediar un precio esta alternativa queda anulada? Y, por otro lado, de ser posible ¿es esto más que una idea teórica, en el sentido de que ha pasado en la realidad?

La información que faltaba para responder estas preguntas viene de Virginie Despentes, una mujer francesa, nacida en la clase media baja, feminista radical, ex prostituta, escritora de libros y películas pornográficas y, como ella misma se define, feliz de tener la libertad de ser fea; una mujer más deseante que deseable. ${ }^{176}$ Ella caracteriza a sus clientes como hombres amables, atentos y tiernos, hace énfasis en que lo más difícil de su trabajo no era lidiar con agresividad o desprecio, sino con su tristeza, soledad y fragilidad al descubierto; sus clientes estaban llenos de humanidad, angustia y fragilidad $^{177}$ y eso era lo más duro de afrontar.

Nos cuenta también sobre sus colegas, diciendo que muchas de ellas eran hermosas, mujeres respecto de las cuales era difícil compadecerse o sentir piedad, sólidas y decididas. Señala que tanto a ella como a sus compañeras el trabajo les fascinaba porque podían conseguir mucho dinero en poco tiempo, pero además siente que le permitió experimentar y cumplir casi todas sus fantasías dejando de lado fantasmas de la moralidad. Con la prostitución sentía que el sexo sólo le pertenecía a ella y a nadie más, y también era rentable; para ella su trabajo era excitante, una afirmación de la autonomía sobre su propio cuerpo y una forma de liberarse de estigmas morales. ${ }^{178}$

El relato de Virginie Despentes deja entrever que en el tiempo que ejerció la prostitución afirmó su autonomía, le permitía apropiarse de su sexualidad, ella misma describe que fue una forma de reparación de una violación que había sufrido con anterioridad. También podemos apreciar que hay un respeto por su subjetividad, en

\footnotetext{
${ }^{176}$ DESPENTES, Teoría King Kong, cit. nota ${ }^{\circ} 1$, p. 9.

${ }^{177}$ DESPENTES, Teoría King Kong, cit. nota $\mathrm{n}^{\circ}$ 1, p. 56.

${ }^{178}$ DESPENTES, Teoría King Kong, cit. nota ${ }^{\circ} 1$, pp. 59 y ss.
} 
efecto, nos cuenta que sentía excitación, placer y curiosidad. Sin embargo, en otras partes de su relato deja ver que algunas veces sintió asco, odio o desprecio por sus clientes y tuvo que fingir que no era así. ${ }^{179}$ En esta línea, podemos afirmar que en la experiencia de la escritora, en al menos algunas de sus relaciones sexuales se cumplió con el imperativo ético. Es decir, ella no fue tratada sólo como un instrumento, sino que se respetó su autonomía y subjetividad. Es necesario destacar que ella ejerció la prostitución por un periodo acotado de tiempo, dos años; que además lo hizo ocasionalmente, y que a pesar de no ser una mujer de clase acomodada, vivía en Francia, un país del primer mundo, cuya realidad dista mucho de lo que acontece en otros países más pobres y menos desarrollados.

Si imaginamos otras condiciones de ejercicio de la prostitución, es evidente que este imperativo sería difícil o imposible de cumplir. Como por ejemplo, si pensáramos en una prostituta que atiende más de cinco clientes por día, sería ilusorio pensar que no siente dolor o que podría llegar a sentir placer; o una que está subordinada a un proxeneta que le impone condiciones o "prestaciones" que ejecutar. Pese a esto, podemos observar del relato de Despentes, que el que la relación sexual tenga un precio, no es obstáculo para que pueda ser ejercida en condiciones moralmente aceptables.

\subsubsection{La prostitución no es per se contraria a la moral}

Un hombre que se plantea consumir prostitución y pretende cumplir con cierto estándar ético debe tener en cuenta que nos encontramos insertos en una cultura que subordina a las mujeres, recordando el análisis de MacKinnon. El cuidado que debería emplear un prostituidor debe ser sumamente exigente, ya que incluso en condiciones como las de Virginie Despentes, en las que ella podía elegir a sus clientes; los servicios que realizaba y la frecuencia con que se prostituía; podemos observar que de todas maneras algunas veces no se cumplió con este imperativo. No obstante, a la hora de analizar este fenómeno no podemos olvidar la multiplicidad de clientes. Aunque algunos de ellos puedan responder a una lógica patriarcal, no siempre son violentos, también los hay amables, ${ }^{180}$ e incluso podemos pensar en clientes que busquen el placer mutuo de la relación. Además, muchos de ellos presentarían problemas relacionales ${ }^{181} \mathrm{y}$, en consecuencia, las soluciones deben ser pensadas de manera minuciosa.

La labor del feminismo debe centrarse en acabar con la subordinación femenina, no ocultando, ni censurando ciertas formas de expresión de la sexualidad, sino pensando en nuevas formas de ejercicio de ella y nuevos parámetros culturales no ajenos sino cercanos a la ética y la moral. Cuando hablamos de relaciones sexuales, esto se cumple con el respeto irrestricto de nuestra subjetividad y nuestra autonomía. Ello tiene directa relación con el imperativo kantiano, pero reinterpretado bajo una óptica feminista, en el sentido de que es una concreción de aquel aplicada a las relaciones sexuales. La instrumentalización no sería per se problemática, sino cuando se trata a alguien exclusivamente como medio, lo que en cuanto al sexo se refiere, implicaría negar su autonomía y su subjetividad.

\footnotetext{
${ }^{179}$ DESPENTES, Teoría King Kong, cit. nota $\mathrm{n}^{\circ} 1$, pp. 56.

${ }^{180}$ LAMAS, “Feminismo y prostitución”, cit., nota ${ }^{\circ} 56$, p. 25.

${ }^{181}$ MONTREYNAUD, Florence, "Penalización de los clientes en Suecia", AÚN CREEMOS EN LOS SUEÑOS (ed.) La prostitución. Debate sobre el derecho a vender el cuerpo: causas de la prostitución; redes internacionales mafiosas; la prostitución infantil, etc., Santiago: Aún creemos en los Sueños., 2004, pp. 18-19.
} 
No podemos dejar de señalar que la conducta de la prostituta tampoco es inmoral si aplicamos estos mismos estándares. En esa línea, existen dos posiciones en las que una mujer puede ejercer la prostitución: la primera es una en que ella lo desea, le gusta y le excita, como acontece en la mayor parte de la experiencia de Despentes; la segunda posición es una en que ella siente a disgusto, pero su situación económica, familiar o incluso psicológica no le permite tomar una decisión de forma libre. Ninguno de estos casos amerita un reproche moral, puesto que en el primero hay un respeto de la autonomía y subjetividad de la prostituta sobre sí misma y en el segundo no hay libertad de elección y, por ende, el reproche moral queda anulado. No hay inmoralidad en el segundo caso, porque la moralidad supone un ejercicio de la libertad y racionalidad, y tal como señala MacKinnon, en muchas ocasiones no existen las condiciones necesarias para que las mujeres efectúen una elección.

En consecuencia, la prostitución no trae aparejados problemas morales siempre y en todos los casos, puesto que, como hemos visto, es posible que para algunas mujeres resulte liberadora; y también es posible que algunos prostituidores reconozcan la autonomía y subjetividad de las mujeres que prestan servicios sexuales. De esta manera, tampoco es válido el argumento de que la prostitución en Chile adolece de objeto ilícito o de que las asociaciones de prostitutas están prohibidas por la Constitución, ya que hemos demostrado que no es una actividad intrínsecamente inmoral.

\section{2. ¿En qué casos debe intervenir penalmente el Estado? ¿Es necesario castigar?}

Ya habiendo dilucidado que la prostitución no está siempre reñida con la moral, la calificación de la prostituta como víctima siempre y en todos los casos, es muy difícil de sostener. La crítica feminista, a nuestro juicio, debería abocarse a aquellos casos en que las prostitutas indudablemente son víctimas de otro. Es necesario también recordar que el sexo no debiera ser visto únicamente en su dimensión de peligro, sino que también en la de placer. Ignorar que el sexo también significa placer supone aumentar el terror sexual y la desesperación que causa el miedo a sufrir agresiones sexuales. ${ }^{182}$

Queda preguntarnos entonces ¿qué pasa en aquellos casos en que sí lo es, es decir, qué pasa cuando la autonomía y subjetividad de la prostituta no son respetadas? Lo primero que debemos aclarar es que esto pasa en un espectro más o menos amplio de casos. Desde una prostituta que ha consentido el acto sexual, pero que siente dolor, o una a quien el cliente le resulta desagradable y en consecuencia su subjetividad es negada; $;{ }^{183}$ hasta la prostitución forzada en donde se le obliga a realizar toda clase de actos sexuales y por ende existe apropiabilidad respecto de ella, y como resultado es ignorada, entre otras cosas, su autonomía.

Parece del todo dudable que el Estado pueda entrometerse en todos los casos en que existe prostitución reñida con la ética. En primer lugar, porque esta situación no se limita a la prostitución, en efecto, en cualquier relación sexual puede darse la negación de autonomía y/o de subjetividad, incluso en el matrimonio. Es más, frecuentemente la moral es transgredida en las relaciones sexuales en cualquier contexto, por ejemplo, cuando no se toma en cuenta que la pareja no tiene deseo de tener relaciones y se le

182 OSBORNE, Raquel, "Debates actuales en torno a la pornografía y a la prostitución", Revista de Sociología, n³0, 1988, pp. 97-105, p. 99.

${ }^{183}$ Es decir, sus deseos, experiencias y sentires no son tomados en cuenta. 
presiona para hacerlo. O cuando una persona solamente se preocupa de procurarse placer a sí misma, desconociendo las necesidades de su compañero o compañera. En segundo lugar, la ética y la moral son campos que deben quedar preeminentemente en el dominio de los individuos y no en el del Estado, y esto no considerando que pertenecen a la esfera privada, sino considerando que las personas tienen derecho a la autodeterminación incluso para consentir la realización de actos reñidos con la ética.

Por supuesto, estas consideraciones no son absolutas, puesto que en la elección de un acto inmoral puede ser lesionado un bien jurídico ajeno y por ende el Estado sí tendría razones para inmiscuirse. En este contexto es necesario establecer un parámetro, un punto de inflexión que autorice la intervención del Ius Puniendi. Nos parece que lo determinante en el caso de la prostitución debiera ser el consentimiento, al menos cuando hablamos de individuos mayores de edad. Este parámetro ya es reconocido por algunos Estados europeos a raíz de la firma del Convenio del Consejo de Europa sobre prevención y lucha contra la violencia contra las mujeres y la violencia doméstica, ${ }^{184}$ mejor conocido como Convenio de Estambul. En él se establece que toda actividad sexual no consentida será constitutiva de violencia sexual y a su vez, el consentimiento debe ser prestado de forma libre, como manifestación del libre arbitrio de las personas. ${ }^{185}$

\subsection{1. ¿Qué caracteriza entonces al consentimiento?}

Para comenzar, el consentimiento es diferenciable de la voluntad, ya que podemos pensar en que una persona consienta en un acto que realmente no desea ejecutar y en consecuencia es contrario a su voluntad real. La voluntad real está más ligada con lo que aquí hemos conceptualizado como subjetividad, es decir, los deseos y experiencias de las personas en una esfera interna. Por el contrario, el consentimiento es un acto exteriorizado, una comunicación efectuada a otro en la que se accede o no a realizar cierto acto o a que el otro realice cierto acto sobre nosotros, independiente de nuestro sentir o nuestros deseos, sean estos expresados o no. ${ }^{186} \mathrm{El}$ consentimiento es una forma de manifestar una voluntad, que puede ser diversa a la real, es decir, es una voluntad exteriorizada, que no necesariamente coincide con la voluntad interna (o real). ${ }^{187}$

El consentimiento no es un acto instantáneo, de si y no, sino que supone una dinámica en la que existen cambios y variaciones en una misma relación, no es algo dicotómico. ${ }^{188}$ Esto implica que a lo largo de la relación sexual el consentimiento puede cambiar. Así, en un inicio puede darse el consentimiento, pero luego puede ocurrir que

\footnotetext{
${ }^{184}$ Convenio del Consejo de Europa sobre prevención y lucha contra la violencia contra las mujeres y la violencia doméstica, 2011. En: https://rm.coe.int/1680462543 [visitado el 04.09.2017].

185 “Artículo 36: Violencia sexual, incluida la violación 1 Las Partes adoptarán las medidas legislativas $o$ de otro tipo necesarias para tipificar como delito, cuando se cometa intencionadamente: a la penetración vaginal, anal u oral no consentida, con carácter sexual, del cuerpo de otra persona con cualquier parte del cuerpo o con un objeto; b los demás actos de carácter sexual no consentidos sobre otra persona; $c$ el hecho de obligar a otra persona a prestarse a actos de carácter sexual no consentidos con un tercero. 2 El consentimiento debe prestarse voluntariamente como manifestación del libre arbitrio de la persona considerado en el contexto de las condiciones circundantes."

${ }^{186}$ De esta manera, un acto sexual consentido podría ser contrario a la moral, por negarse la subjetividad del compañero o compañera sexual.

${ }^{187}$ En este sentido véase también PÉREZ, Yolinliztli, "Consentimiento sexual: un análisis con perspectiva de género", Revista Mexicana de Sociología, vol.78 n4, México, 2016, p 747.

188 PÉREZ, Yolinliztli: “Consentimiento sexual: un análisis con perspectiva de género”, Revista Mexicana de Sociología, vol.78 n4, México, 2016, p 752.
} 
la persona cambie de parecer y en consecuencia retire su consentimiento. Esto puede suceder por alguna razón en particular, como por ejemplo, el sentir dolor, o bien, sin razón alguna, puesto que el consentimiento sexual es también arbitrario y en consecuencia no es necesario que quien consiente o no consiente dé razones de por qué lo hace. Esto implica que debe ser perdurable, es decir, subsistir durante toda la relación sexual. Evidentemente todo lo dicho es predicable respecto de la prostitución y en consecuencia la prostituta puede en cualquier momento y sin expresión de causa, retirar su consentimiento y el cliente debe detenerse o de lo contrario someterse al reproche del Ius Puniendi. ${ }^{189}$

El consentimiento es también específico, ya que se da respecto de ciertos y determinados actos. En consecuencia, consentir para realizar cierto acto sexual no implica consentir para realizar cualquier acto o todos los actos. Así, en el contexto de la prostitución, si la prostituta consiente en tener sexo vaginal con penetración, eso no significa que consienta al sexo anal u oral, ni siquiera que consienta a un beso u otra acción sexual.

Además debe ser oportuno, es decir, debe ser dado en el momento mismo y durante la actividad sexual; de este modo, no es relevante el consentimiento prestado con anterioridad, ya sean días, horas o minutos atrás. Esto significa además, que el que una persona preste su consentimiento una vez o frecuentemente, no conlleva a que sea un consentimiento perpetuo o para todas las veces. Por ejemplo, si una prostituta tiene un cliente que la frecuenta todos los viernes durante dos años y ellos han pactado ese día y horario, la prostituta puede negarse a realizar el acto sexual ya sea antes, o en ese mismo momento.

El consentimiento es un acto que debe ejecutarse de forma libre, es una elección y por ende es necesario que quien consiente lo haga estando en sus plenas facultades racionales y volitivas y en ausencia de toda presión o coacción. Esta característica puede resultar compleja cuando es aplicada a la prostitución, toda vez que es frecuente que la prostituta se encuentre en una situación de extrema necesidad y desvalimiento. En este caso, debemos analizar si ella tenía en la práctica otras opciones de subsistencia; de no tenerlas, estaríamos ante una ausencia de consentimiento y por ende en una situación punible. Esto evidentemente no implica que pueden ser descartados otros elementos del delito, así por ejemplo, para que el cliente pueda ser sancionado debe estar en conocimiento de esta situación.

En conclusión, el consentimiento es diferenciable aunque relacionado con la voluntad, se caracteriza por ser dinámico, arbitrario, perdurable, específico, oportuno y libre. En consecuencia, cualquier conducta que signifique la transgresión de estas características, debe ser penalizada. Más adelante analizaremos cuándo esto ocurre y si la regulación actual es o no suficientemente protectora del consentimiento prestado en el ámbito de la prostitución.

La razón de por qué nos parece relevante el consentimiento es que estimamos que a través de él es que se concretiza la libertad sexual, bien jurídico tutelado por los delitos sexuales en contra de mayores de edad. La libertad sexual implica el derecho a la autodeterminación, íntimamente conectado con la dignidad humana, que reconoce como

${ }^{189}$ Las implicaciones civiles de esta situación son un tema aparte. 
único límite el respeto por la libertad ajena. ${ }^{190}$ Nuestra caracterización del consentimiento no obedece a otra cosa que a hacer palpable la libertad sexual, sin condiciones ni excepciones, sin convertirla en una mera declaración de principios.

5.2.2. ¿Qué rol juega el Estado en aquellos casos en que la prostitución transgrede a la ética, pero en donde no existe ausencia de consentimiento?

Es evidente que en muchos casos en que el cliente contrata a una prostituta no respeta sus deseos, experiencias y/o su autonomía. En efecto, tal como MacKinnon nos muestra, es posible que existan prostituidores que disfruten con el dolor, el disgusto y la sumisión de la prostituta, aunque quizás ella consienta en esos actos por diversas razones. ${ }^{191}$ En estos casos, podemos certeramente afirmar que a la prostitución subyace un problema de género, con raíces en el patriarcado. Nos parece asertivo lo señalado por De Miguel, en cuanto a que (al menos algunos de) los que contratan a una prostituta encuentran placer en relaciones carentes de reciprocidad, ${ }^{192}$ relaciones en que se comercia con la intimidad de los cuerpos. ${ }^{193}$ Esto es claramente un problema de género, toda vez que los hombres son quienes principalmente consumen prostitución y no las mujeres.

Sin embargo, la cuestión que nos parece relevante es si el Derecho Penal es el instrumento adecuado para solucionar este problema. Es más, legítimamente nos preguntamos si el recurso al Poder Punitivo no tiene que ver también con el pánico moral asociado a la prostitución y a la liberalización de las costumbres sexuales en general. Tal como señala Pateman, el "contrato sexual" tiene su base principalmente en el matrimonio, ${ }^{194}$ que sería la expresión fundamental de la subordinación femenina. Si bien es cierto que la institución del matrimonio ha cambiado enormemente, aún hoy existen mujeres que deben contraerlo para sortear las necesidades económicas o simplemente por presión social. Y, corriendo el riesgo de ser majaderos, nadie intenta criminalizar el matrimonio, nadie alega la falta de libertad que una mujer puede experimentar al contraerlo. Como señala Mestre, "todas y todos negociamos a diario con el patriarcado desde distintas posiciones, igual que negociamos con otros sistemas de dominio"; así, según la autora "tenemos capacidad de elección, aunque sea un margen pequeño". 195

Es cierto que las críticas feministas a la división de lo público y lo privado ${ }^{196}$ han tenido relucientes frutos, por ejemplo, en algunos delitos sexuales el bien jurídico ha pasado a ser la libertad sexual en vez del honor o la honestidad. ${ }^{197}$ Sin embargo, no es acertado señalar que el Derecho Penal es el instrumento adecuado para dotar de mayor igualdad y poder a las mujeres. ${ }^{198}$ Es importante hacer notar que el discurso de mayor protección a

\footnotetext{
${ }^{190}$ RODRÍGUEZ, Luis, Delitos Sexuales, Santiago: Editorial Jurídica de Chile, 2014.

${ }^{191}$ Existiendo así una divergencia entre su voluntad real y su voluntad declarada.

192 DE MIGUEL, "La prostitución de mujeres", cit., nota ${ }^{\circ} 123$, p. 10.

${ }^{193}$ MONTREYNAUD, "Penalización de los clientes en Suecia”, cit., nota n 181, p. 19.

${ }^{194}$ PATEMAN, El contrato sexual, cit., nota n'88, pp. 11, 15 y 16.

${ }^{195}$ MESTRE, “Trabajo, igualdad y reconocimiento de derechos”, cit., nota n¹32, p. 32.

${ }^{196}$ Sobre ello ampliamente, PATEMAN, "Críticas feministas a la dicotomía público/privado", cit. nota n ${ }^{\circ}$ 66.

${ }^{197}$ MAQUEDA, María Luisa, “Es la estrategia penal una solución a la violencia contra las mujeres? Algunas respuestas desde un discurso feminista crítico", InDret, Revista para el Análisis del Derecho, n4, 2007, pp. 363-408, p. 7.

${ }^{198}$ LARRAURI, Elena, Criminología crítica y violencia de género, Madrid: Editorial Trotta, 2007, p. 19.
} 
las mujeres no puede ser a costa de anular su capacidad de decisión. ${ }^{199}$ Súmese a esto que, al hacerlo, el feminismo está legitimando el Poder Punitivo, mermando su potencial de transformación social. ${ }^{200}$

A pesar de que no estamos de acuerdo en el recurso al Derecho Penal en este ámbito, el Estado no debería quedarse al margen de las situaciones que merman la dignidad de las personas y en particular de las mujeres. Nuestra propuesta es una alternativa a la criminalización, en el sentido de que sugerimos la creación de políticas públicas destinadas a educar a la población e instarla a mantener relaciones en donde la reciprocidad sea la norma. Una intervención estatal no coercitiva, sino informativa, en la que se fomente la reflexión en torno a la sexualidad, al placer y a la dignidad de las personas. Esto significaría también un avance para todas las mujeres. De todas maneras tendría efectos positivos en los eventuales clientes, que serían más proclives a respetar las condiciones y deseos de la prostituta.

\section{Legalización feminista para Chile}

\subsection{La prostitución en Chile}

Ya hemos realizado un análisis exhaustivo de los argumentos de una y otra postura, así como también hemos tomado una postura moral respecto a la prostitución y establecido un parámetro de intervención del Ius Puniendi. Hemos de proceder entonces a formular una propuesta concreta para Chile. Para ello, comenzaremos por analizar el tratamiento de la prostitución que ha habido en Chile hasta ahora, para concluir con la formulación de reformas legales que sean respetuosas del consentimiento.

En cuanto a la regulación de la prostitución, en nuestro país es bastante escasa, y ella se plantea solo desde dos perspectivas. Por una parte, encontramos el Código Sanitario y el Reglamento sobre Infecciones de Transmisión Sexual, ambos clásicamente abocados a regular la prostitución como potencialmente transmisora de enfermedades venéreas. Por otro lado, encontramos al Código Penal, que la criminaliza en ciertas circunstancias que considera atentatorias contra bienes jurídicos. Todo esto sin perjuicio de que las normas de la Constitución eventualmente le sean aplicables, como aquellas relativas a los Derechos Fundamentales, en especial, en lo referente a la libertad económica. ${ }^{201}$

\subsubsection{Disposiciones sanitarias relativas a la prostitución}

El Código Sanitario establece en el artículo 41 el deber de llevar una estadística sanitaria de las personas que se dedican al comercio sexual. Además de ello, prohíbe la agrupación de prostitutas en prostíbulos o casas de tolerancia. ${ }^{202}$ Se prescribe asimismo que corresponde a las prefecturas de carabineros hacer cumplir este artículo, vale decir,

\footnotetext{
${ }^{199}$ LARRAURI, Elena (coord.), Mujeres, Derecho Penal y Criminología, España, Editorial Siglo XXI, 1994, p. 8.

200 ZAFFARONI, Eugenio: "El discurso feminista y el poder punitivo", en: HAYDÉE, Birgin (compiladora), Las trampas del poder punitivo: El género del derecho penal, Argentina: Editorial Biblos, 2000, p. 37.

${ }^{201}$ Artículo 19 n²1. Sobre este punto, ampliamente SAEZ, Carolina; ARAVENA, Fabián:, “El derecho a ejercer el comercio sexual en Chile”, IV Congreso de Teoría Constitucional de la Universidad de Chile, Santiago, 2008.

${ }^{202}$ Artículo 41, Código Sanitario Editorial Thomson Reuters, 2017.
} 
llevar las estadísticas y clausurar los locales. ${ }^{203}$ Esta norma claramente posee tintes reglamentaristas, promoviendo el control policial sobre las prostitutas.

En cuanto al Reglamento sobre Infecciones de Transmisión Sexual, hasta antes del año 2007 se establecían diversas prohibiciones. ${ }^{204}$ En primer lugar, se obligaba a que quien "a juicio de carabineros" se dedicara al comercio sexual, fuera enviado a un establecimiento de salud, quien además debía realizarse exámenes médicos. En segundo lugar, se reiteraba la prohibición del Código Sanitario, en orden a proscribir los prostíbulos o casas de citas. En tercer lugar, se prohibía cualquier forma de propaganda que promoviera el comercio sexual. En cuarto lugar, se prohibía que los propietarios o administradores de inmuebles los dieran en arrendamiento o permitieran que fueran ocupados para el comercio sexual; y, en la misma línea, no se permitía tomar en arriendo u ocupar un inmueble para esos fines. En quinto y último lugar, se señalaba que todas las personas que se encontraren al interior de un inmueble en donde se ejerza la prostitución debían ser llevadas de inmediato al servicio de salud para realizarles exámenes. ${ }^{205}$

Estas normas tenían una marcada connotación reglamentarista, siendo similares a las "contagious disease acts" contra las que tanto lucharía Josephine Butler. Ellas promovían un fuerte control policial sobre las prostitutas (aún más drástico que el del Código Sanitario). Control que pecaba de arbitrariedad, ya que dejaba al juicio del policía la determinación de si una mujer se dedicaba al comercio sexual. Eran además intrusivas respecto de la integridad física de la trabajadora sexual, ya que la obligaban a realizarse exámenes médicos. Todo esto era en extremo lesivo de sus derechos, sobre todo considerando que tales reglas provenían de un reglamento y no de una ley. No se entendía tampoco el ímpetu en extinguir las casas de tolerancia, ya que en realidad en ellas el control sanitario es más sencillo que en otros lugares. Cabe destacar que esta última crítica es aplicable a la regulación presente hoy en el Código Sanitario.

El año 2007 dicho reglamento fue reemplazado por uno nuevo debido a su desactualización, el "Reglamento sobre Infecciones de Transmisión Sexual", publicado en 2007. Todas las normas detalladas en el párrafo precedente fueron eliminadas. En el reglamento actual sólo una norma hace referencia a la prostitución, a saber, el artículo 9. Él dispone que los servicios de salud deben disponer de horas para la atención de personas cuya conducta sexual sea de alto riesgo, siendo la prostitución una más de ellas. ${ }^{206}$ El reglamento asegura la completa voluntariedad y confidencialidad de los exámenes, siendo respetuoso del principio de legalidad y de los Derechos Fundamentales de la prostituta. Vemos como algo positivo la nueva forma en que el reglamento aborda la prostitución, ya que lo hace sin el prejuicio moral que caracterizaba a la regulación precedente. Dicha normativa reconoce que la prostitución es una conducta sexual de riesgo, pero asume que lo es como cualquier otra, por ejemplo, la promiscuidad. No obstante, este nuevo reglamento es criticable en cuanto

\footnotetext{
${ }^{203}$ Artículo 41, Código Sanitario, cit., nota ${ }^{\circ} 202$.

${ }^{204}$ IGLESIAS, Margarita, "De lacra social a comercio sexual", AÚN CREEMOS EN LOS SUEÑOS (ed.), La prostitución. Debate sobre el derecho a vender el cuerpo: causas de la prostitución; redes internacionales mafiosas; la prostitución infantil, etc., Santiago: Aún creemos en los Sueños, 2004, p. 65. ${ }^{205}$ GONZALEZ, Regulación penal del meretricio, cit. nota $\mathrm{n}^{\circ}$ 13, p. 107 y 108.

206 Reglamento sobre Infecciones de Transmisión Sexual, publicado en 2007. En: https://www.leychile.cl/Navegar?idNorma=260650 [visitado el 01.09.2018], artículo 9.
} 
deja todas estas materias completamente fuera de tratamiento, lo que en último término ha implicado su regulación por una serie de ordenanzas municipales. ${ }^{207}$

\subsubsection{Disposiciones penales relativas a la prostitución}

En cuanto a la regulación penal, como un fiel reflejo de las cruzadas del abolicionismo contemporáneo, es castigado el proxenetismo y la compra de servicios sexuales, siempre y cuando estén referidos a menores de edad. Así, se sanciona al que promoviere o facilitare la prostitución de menores de edad para satisfacer los deseos de otro, con la pena de presidio menor en su grado máximo. ${ }^{208}$ Esta figura es denominada por la doctrina como proxenetismo. ${ }^{209}$ Se castiga también la obtención de servicios sexuales mediante precio, prestados por un mayor de catorce años, pero menor de dieciocho, sin que medien las condiciones exigidas por los tipos de violación o estupro. La sanción a esta conducta es idéntica a la anterior. ${ }^{210}$

Se sanciona igualmente la trata de personas para el ejercicio de la prostitución. La conducta incriminada es la promoción o facilitación de la entrada o salida del país de una persona para que ejerza la prostitución. La pena asignada a este delito es igual a la de los delitos anteriores, pero se suma la de multa de 20 a 30 UTM. $^{211}$

En cuanto a la prostitución realizada voluntariamente por mayores de edad, aparte del tipo señalado en el párrafo anterior, parece no existir norma que lo penalice. No obstante, algunos han defendido que el artículo $373^{212}$ prevé el castigo a la prostitución al referirse a las ofensas al pudor y las buenas costumbres. Esto se señala con relación a la existencia de prostíbulos o casas de tolerancia, o bien, de la prostitución callejera. ${ }^{213}$ Sin embargo, nosotros no compartimos dicha opinión. La eventual aplicación de este artículo debe realizarse con extrema cautela, ya que no corresponde al Derecho Penal sancionar infracciones puramente morales.

Creemos que una lógica como la de José Luis Diez respecto de las conductas exhibicionistas es más pertinente. Él considera que estas solo serán punibles en la medida que impliquen un atentado contra el bien jurídico protegido que no es otro que la libertad sexual, cuyo titular es el individuo y no la sociedad, no siendo posible su castigo por razones de prevención especial. ${ }^{214}$ En consecuencia no puede ser aplicado este tipo por razones de orden social o mero control. La libertad sexual resulta lesionada con conductas exhibicionistas cuando aquellas privan o limitan la disposición de la sexualidad de un individuo.

\footnotetext{
207 RIVERA, José, “Algunos apuntes jurídicos sobre la prostitución en Chile”, Boletín Mexicano de Derecho Comparado, $\mathrm{n}^{\circ} 148,2017$, pp. 361-392, pp. 384-385.

${ }^{208}$ Artículo 367 del Código penal, 2018. En: https://www.leychile.cl/Navegar?idNorma=1984 [visitado el 01.09.2018].

${ }^{209}$ GONZALEZ, Regulación penal del meretricio, cit. nota $\mathrm{n}^{\circ} 13$, p. 140.

${ }^{210}$ Artículo 367 ter, Código penal, cit., nota ${ }^{\circ} 208$.

211 Artículo 411 ter, Código penal, cit., nota ${ }^{\circ} 208$.

${ }^{212}$ Artículo 373: "Los que de cualquier modo ofendieren el pudor o las buenas costumbres con hechos de grave escándalo o trascendencia, no comprendidos expresamente en otros artículos de este Código, sufrirán la pena de reclusión menor en sus grados mínimo a medio”, Código penal, cit., nota n 208.

${ }^{213}$ RIVERA, “Algunos apuntes jurídicos sobre la prostitución en Chile”, cit. nota n² 207, pp. 379 y 380.

${ }^{214}$ DIEZ RIPOLLÉS, José Luis, Exhibicionismo, pornografía y otras conductas sexuales provocadoras, España: Editorial BOSCH, 1982, p. 538.
} 
Esto sucede cuando se involucra al sujeto pasivo en una acción sexual sin su consentimiento, es decir, cuando el observador de la conducta sexual se convierte en el "compañero" de quien la ejecuta. ${ }^{215}$ Podemos imaginar por ejemplo, el caso clásico del hombre voyerista que muestra sus genitales a mujeres en la calle con el objeto de acosarlas. Evidentemente, no en todos los casos en que hay una conducta exhibicionista el espectador pasa a formar parte de la conducta sexual y en una sociedad pluralista y democrática, no puede sancionarse un delito carente de víctima o que no lesione ningún bien jurídico. Una interpretación que considerara que la prostitución per se debe ser sancionada por ofender al pudor y las buenas costumbres sería lesiva de los principios de una sociedad democrática, toda vez que meramente hay lesión de sentimientos individuales, los que según José Luis Diez son irrelevantes penalmente ${ }^{216}$.

\subsubsection{Otras disposiciones civiles y constitucionales}

José Rivera ${ }^{217}$ ha estimado que la prostitución se encuentra reñida con las normas civiles, puesto que adolece de objeto ilícito ${ }^{218}$ toda vez que para él hay un arrendamiento de una parte del cuerpo en la prostitución. Como el cuerpo es un bien incomerciable, concluye que cualquier contrato de prostitución adolece de objeto ilícito. Sin embargo, no da razones suficientes de por qué es un arrendamiento de una parte del cuerpo y no un arrendamiento de servicios, tal como cualquier otro. Como profundizaremos más adelante, en todos los trabajos se utiliza el cuerpo y no parece coherente afirmar que este se arriende, toda vez que no se separa del resto del cuerpo, ni deja de tener la facultad de moverse.

En nuestra opinión, y pese a que la prostitución tiene sus particularidades, en cuanto a lo que al objeto contractual respecta, no parece tener diferencias sustanciales a cualquier otro arrendamiento de servicios. Lo que se hace no es arrendar los genitales de la prostituta ni mucho menos venderlos, sino pactar la realización de una cierta conducta, es en consecuencia una obligación de hacer y no de dar. Así, cuando contratamos a un escritor no estamos pagando por su mano, sino por la actividad que realiza con ella. En consecuencia, la conclusión de Rivera parece del todo desacertada.

El mismo autor ha planteado que además de adolecer de objeto ilícito, adolece de causa ilícita $^{219}$, puesto que la considera como un hecho inmoral. Sin embargo, asume de plano que lo es, adoptando en realidad un prejuicio del que no da suficiente sustento. En el mismo sentido podría plantearse que además es inconstitucional, o al menos que la asociación para prostituirse lo es, ya que la Constitución prohíbe las asociaciones contrarias a la moral. ${ }^{220}$ Sin embargo, tal como nosotros hemos estudiado en el capítulo 5.1 de este artículo, la prostitución no es en realidad inmoral si efectuamos un análisis riguroso y racional, simplemente, nuestra sociedad no está acostumbrada a aceptarla.

\footnotetext{
${ }^{215}$ DIEZ RIPOLLÉS, Exhibicionismo, pornografía, cit. nota n ${ }^{\circ} 214$, p. 166.

${ }^{216}$ DIEZ RIPOLLÉS, Exhibicionismo, pornografía, cit. nota n ${ }^{\circ} 214$, pp.162 y ss.

${ }^{217}$ RIVERA, “Algunos apuntes jurídicos sobre la prostitución en Chile”, cit. nota $n^{\circ} 207$.

${ }^{218}$ Artículo 1464: Hay un objeto ilícito en la enajenación: $1^{\circ}$. De las cosas que no están en el comercio; (...). Código Civil, 2018, cit. nota ${ }^{\circ} 156$

219 Artículo 1467 inciso 3: "Así la promesa de dar algo en pago de una deuda que no existe, carece de causa; y la promesa de dar algo en recompensa de un crimen o de un hecho inmoral, tiene una causa ilícita." Código Civil, cit. nota ${ }^{\circ} 156$.

${ }^{220}$ Artículo $19 \mathrm{n}^{\circ} 15$ inciso 4: "Prohíbense las asociaciones contrarias a la moral, al orden público y a la seguridad del Estado." Constitución Política de la República, cit., nota n 155.
} 


\subsubsection{Análisis del sistema chileno}

De lo expuesto hasta aquí podemos constatar que en Chile no se adopta ningún modelo a cabalidad y existe más bien un vacío normativo. Las pocas normas que existen en lo relativo a los mayores de edad tendrían tintes reglamentaristas (aunque en un sentido mucho más débil desde el 2007). Por otra parte, en lo relativo a los menores de edad y a la trata de personas la regulación sería abolicionista. En consecuencia nuestro modelo sería uno mixto si es que a podemos interpretar la escases de normar como la adopción de un modelo.

No obstante, en este punto resulta manifiesto que nuestra regulación es del todo deficiente en el aseguramiento de los derechos de las prostitutas. No existe ninguna norma que aborde completamente los problemas que se presentan en el ejercicio de la prostitución. Esto resulta especialmente preocupante en cuanto al trabajo que se realiza por cuenta ajena. ${ }^{221}$ Pese a que se prohíbe la existencia de prostíbulos, es decir, de lugares en donde concertadamente se practique el trabajo sexual, nada obsta a que este se realice a través de agencias telefónicas que presten servicios a domicilio, por ejemplo. Este es uno de los casos en que la prostituta quedará completamente desprotegida frente a las imposiciones de su empleador o de sus clientes. Tampoco existen normas relativas al trabajo por cuenta propia o asociado, lo que puede llevar a mayor vulnerabilidad. Además, mientras la prostitución no sea legalizada como un trabajo, siempre habrá quienes defiendan la postura de que no es tal, de que es indigna y contraria a Derecho. ${ }^{222}$

\subsubsection{Movimiento pro legalización en Chile}

Más allá de la realidad normativa, en Chile no solamente ha habido iniciativas abolicionistas y reglamentaristas. Quienes abogan por la legalización también han encontrado su espacio en nuestro país. La Fundación Margen existe desde 1998 y hoy forma parte de la Red de Trabajadoras Sexuales de Latinoamérica y el Caribe, organización que ha promovido la legalización en toda Latinoamérica. Ella existe con el objeto de impulsar políticas tendientes al aseguramiento de los derechos de las prostitutas. En sus propias palabras: “(...) se ha buscado que las mujeres trabajadoras sexuales se constituyan como sujeto de derecho y protagonistas en el desarrollo de futuras políticas sobre el trabajo sexual". 223

Esta organización impulsa desde sus inicios programas de información, autocuidado, campañas de sensibilización, realiza propuestas políticas y legales, etc. Aspira a alcanzar la igualdad en derechos y en dignidad de las trabajadoras sexuales. ${ }^{224}$ Cuenta además con una serie de documentos en donde argumenta a favor del libre acceso al aborto, una guía de buenas prácticas para el personal de salud, etc. Incluso, en 2016 esta agrupación ganó el premio Elena Caffarena. ${ }^{225}$

\footnotetext{
${ }^{221}$ Para mayor claridad sobre los conceptos de trabajo por cuenta ajena, propia y asociado Vid. infra 6.2.

${ }^{222}$ Tal como defiende, RIVERA, “Algunos apuntes jurídicos sobre la prostitución en Chile”, cit. nota $n^{\circ}$ 207, pp. 179 y ss.

${ }^{223}$ FUNDACIÓN MARGEN, “Quiénes somos”, En: http://fundacionmargen.cl/quienes-somos/\#.WgDN9WWbIU [visitado el 28.08.2018].

${ }^{224}$ FUNDACIÓN MARGEN, “Misión y visión”, En: http://fundacionmargen.cl/quienes-somos/misionvision/\#.WgD_ytWWbIU [visitado el 28.08.2018].

225 "8 de marzo: trabajadoras sexuales en chile recibieron el premio Elena Caffarena 2016”, RedTraSex, En: http://www.redtrasex.org/spip.php?article2263 [visitado el 28.08.2018].
} 
También está el "Sindicato Nacional Independiente de Trabajadoras Sexuales Travestis, Transgéneras y Otras, Amanda Jofré", pertenecientes a la Red Lactrans. Son un sindicato de prostitutas transgénero y travestis que ha luchado por la legalización en Chile, pidiendo la derogación del artículo 41 del Código Sanitario. También han realizado un arduo trabajo en la prevención y tratamiento de las enfermedades de transmisión sexual, así como también en la elaboración de leyes de identidad de género. $^{226}$

En lo que respecta a los estudios académicos del Derecho, la verdad es que la bibliografía es en extremo escasa. Tanto Luis Rodríguez ${ }^{227}$ como Manuel González $^{228}$ parecen apreciar el fenómeno desde un punto de vista meramente descriptivo, limitándose a realizar apreciaciones solamente respecto de la prostitución de menores de edad, sin pronunciarse en profundidad sobre la prostitución de mayores de edad. El único trabajo acabado es el de José Rivera, ${ }^{229}$ pero se hace desde la perspectiva del Derecho Civil y argumenta a favor de la abolición, por considerar que la prostitución adolece de causa ilícita. En efecto, las y los académicos, sobre todo en el ámbito penal, parecen no haberse ocupado de la prostitución de mayores de edad.

\subsection{Propuestas de reforma}

\subsubsection{Trabajo, sí. Como cualquier otro, no}

Cuando afirmamos que la prostitución es un trabajo, lo que en realidad buscamos es el reconocimiento legal de ella. Para esto, es necesario tener en cuenta las diferentes formas laborales que ha de revestir. Luego de ello, hemos de preguntarnos si estamos a favor de la legalización de todas estas formas, analizando si efectivamente es un trabajo como cualquier otro.

Antes de dar nuestra opinión respecto de cuáles de estas formas laborales deben legalizarse, creemos necesario precisar algunos puntos respecto de la caracterización de la prostitución como trabajo. En lo que a nosotros respecta, creemos que el hecho de que la cuestión en juego sea el sexo, no imprime en esta relación nada esencialmente distintivo de otras. No creemos que haya algo en él que haga que la prostitución sea una actividad indigna o denigrante. Tampoco creemos que siempre y en todos los casos atente contra los Derechos Fundamentales de la prostituta. Esto es eventual y se presenta también en otras relaciones laborales, y lo cierto es que nadie intenta penalizar la minería debido a los problemas pulmonares o de salud en general que puede ocasionar en los mineros, por ejemplo.

No obstante lo anterior, nos parece que no es un trabajo como cualquier otro. Nos aventuraremos a plantear ciertos puntos que nos hacen llegar a tal conclusión. En primer lugar, la prostitución tiene por objeto una función humana fundamental, que se relaciona íntimamente con la personalidad de un ser humano, es decir la sexualidad. En segundo

\footnotetext{
${ }^{226}$ SINDICATO NACIONAL INDEPENDIENTE DE TRABAJADORAS SEXUALES TRAVESTIS, TRANSGÉNERAS Y OTRAS AMANDA JOFRÉ, "Nuestra historia". En: http://www.amandajofre.cl/historia.html [visitado el 28.08.2018].

${ }^{227}$ RODRÍGUEZ: Delitos Sexuales, cit., nota ${ }^{\circ} 190$.

${ }^{228}$ GONZALEZ: Regulación penal del meretricio, cit., nota $n^{\circ} 13$.

${ }^{229}$ RIVERA, "Algunos apuntes jurídicos sobre la prostitución en Chile”, cit. nota n²07, pp. 361-392.
} 
lugar, dicha función implica un contacto con la corporalidad, un traspaso de los límites físicos. ${ }^{230}$ En tercer lugar, en su realización comúnmente están involucrados los fluidos corporales, tanto saliva, como líquido seminal.

Estas características no se presentan de forma frecuente en cualquier trabajo. Así, la prostitución más bien se asemeja a otras actividades económicas que podrían considerarse laborales. Un ejemplo bastante similar lo constituyen quienes permiten la prueba de medicamentos en su organismo a cambio de una remuneración. A nuestro juicio, estas características demandan un especial cuidado a la hora de regular.

Antes de dar nuestra propuesta hemos de definir las formas laborales que puede revestir la prostitución, en realidad ellas son las mismas que en cualquier otra clase de actividad lucrativa a saber:

En primer lugar, tenemos al trabajo asalariado. Este se caracteriza por ser personal, voluntario, retribuido, por cuenta ajena y bajo dependencia o subordinación. ${ }^{231}$ Son estas dos últimas características las que merecen especial atención. La ajenidad implica que los riesgos serán de cargo del empleador, quien será el responsable del desempeño económico de la empresa, ${ }^{232}$ pero además supone que las ganancias serán cedidas al empresario. Por su parte, la dependencia o subordinación se manifiesta en las facultades de dirección, organización, fiscalización y disciplina, es decir, existe un vínculo de sujeción y mando. ${ }^{233}$ En el caso de la prostitución, esto podría significar, entre otras cosas, que la prostituta sólo podrá ejercer su actividad en el lugar y horario establecidos por el empleador; prestará sus servicios sexuales de forma exclusiva a un único empresario; obedecerá sus órdenes e instrucciones, que podrán estar referidas a los clientes o a la clase de prestaciones; y será supervisada en el cumplimiento de su labor. $^{234}$

En segundo lugar, tenemos el trabajo autónomo. En él no existe una imposición de terceros respecto de su modo de ejecución y, por ende, los frutos del trabajo no son cedidos. El trabajador es propietario de los bienes y servicios que ofrece, sin existir una empresa de por medio, solamente existe una relación contractual de carácter civil en que la prostituta es prestadora de servicios y el cliente es arrendatario de ellos. ${ }^{235}$ Esta es una forma de trabajo individual, en la que la prostituta generalmente atiende al cliente en su departamento.

En tercer lugar, está el trabajo asociado. Este puede asumir diversas formas, algunas reguladas y otras no, puede presentarse en una modalidad auténticamente societaria, o simplemente como asociación de hecho. ${ }^{236}$ A nuestro juicio la forma más adecuada de organización en esta materia son las cooperativas, que ayudarían a las trabajadoras a acceder a servicios económicos y sociales, como por ejemplo, la salud, los créditos, la

\footnotetext{
${ }^{230}$ Esto podría no presentarse en ciertos casos, como lo sería el de la masturbación realizada de parte de una prostituta a un cliente.

${ }^{231}$ LIZAMA, Luis, Derecho del Trabajo, Santiago: Editorial Lexis Nexis, 2003, pp. 8, 9 y 10.

${ }^{232}$ LIZAMA: Derecho del Trabajo, cit. nota ${ }^{\circ} 231$, p. 10.

${ }^{233}$ ROJAS, Irene, "Manual de Derecho del Trabajo", Santiago: Editorial Lexis Nexis, 2004, p. 25.

${ }^{234}$ En aplicación de los elementos propuestos por ROJAS, Manual de Derecho del Trabajo, cit. nota n²33, p. 27.

${ }^{235}$ GAY, "Fórmulas jurídicas”, cit. nota n¹74, pp. 130 y ss.

${ }^{236}$ LÓPEZ, Frederic, "Prostitución y Estatuto Profesional", en: CERRA, Rosario, Prostitución y Trata, Valencia: Editorial Tirant lo Blanch, 2007, pp. 157-202, p. 178.
} 
vivienda, etc. Las cooperativas han servido históricamente para organizar y dar voz a los trabajadores. Lo que caracteriza al trabajo asociado es que se presta de forma remunerada, carente de ajenidad y con cierto grado de dependencia como exigencia funcional. ${ }^{237}$ En la cooperativa, los trabajadores de vinculan con ella en relación societaria y no laboral, ya que son propietarios.

A la luz de esta última organización, serían las mismas trabajadoras quienes determinarían las reglas de su trabajo, los horarios y prestaciones. El trabajo asociado tampoco excluye otras modalidades societarias, siendo a ellas a quienes corresponde determinar la forma que mejor les acomode. Esto permitiría evitar la intervención ajena, posibilitando que ellas mismas retengan sus ganancias y haciendo palpable la libertad sexual.

\subsubsection{Criminalización del trabajo por cuenta ajena}

Cuando nos referimos a trabajo por cuenta ajena, estamos haciendo referencia a una clase de proxenetismo en particular. En términos amplios, el proxeneta es "aquella persona que, para satisfacer deseos sexuales de otra, facilita medios, encubre, concierta o permite en su casa esa comunicación". ${ }^{238}$ Quien ejerce el proxenetismo lucra del ejercicio de la actividad por parte de otro, generalmente una mujer. Existen varias clases de proxenetismo, sin embargo, una de ellas nos resulta especialmente problemática, puesto que existe una relación de dependencia y subordinación. Esto se presenta respecto de los dueños de clubs o bares, quienes establecen normas a quienes ejercen la prostitución, como por ejemplo, la realización diaria de una cierta cantidad de servicios sexuales, el cobro de un porcentaje de las ganancias o el cumplimiento de un horario determinado, es decir, actúa sobre las prostitutas como un verdadero empleador o patrón.

Debemos recalcar que, de legalizarse el trabajo por cuenta ajena, este también tendría una característica singular; la prestación no iría destinada al empleador, es decir al proxeneta, sino que a un tercero, el cliente. Esto resulta especialmente problemático, ${ }^{239}$ ya que implica que las ganancias de la prostituta serán en parte recibidas por otra persona, y que la prostituta sólo recibirá entre un 25 y $50 \% .{ }^{240}$ En este contexto, nos parece que la libertad sexual puede volverse meramente simbólica. ${ }^{241}$

En este punto resulta del todo relevante nuestra caracterización del consentimiento. Hemos de recordar que para que el consentimiento sea tal es necesario que se respeten sus características, es decir, que se preste en un contexto que le permita ser dinámico, arbitrario, perdurable, específico, oportuno y libre. Esta caracterización evidentemente es una feminista, ya que es ajena a la clásica división machista de mujeres madres y mujeres putas, las primeras puras, carentes de deseos y las segundas, viciosas, que se merecen los abusos cometidos contra ellas. Asume el empoderamiento sexual, sobre

\footnotetext{
${ }^{237}$ GAY: "Fórmulas jurídicas", cit., nota n 174, pp. 133 y 134.

${ }^{238}$ GARRIDO, “La prostitución”, cit. nota ${ }^{\circ}$ 5, p. 100.

${ }^{239}$ En otros países han existido iniciativas que resolverían este problema. Un ejemplo fue el proyecto de la Ley Catalana de Limitación de Servicios Sexuales Remunerados, que descartaba el trabajo asalariado, buscando eliminar a los intermediarios. GAY, "Fórmulas jurídicas”, cit. nota $\mathrm{n}^{\circ} 174$, p. 135.

${ }^{240}$ LAMAS: “Feminismo y prostitución”, cit. nota ${ }^{\circ} 56$, p. 25.

${ }^{241}$ Cabe destacar que nuestra opinión sería la misma en caso de que existiera una especie de "agencia" de personas para pruebas de medicamentos que retuviera a veces más del 50\% de las ganancias.
} 
todo femenino y es ajena a cualquier forma de imposición de una conducta pasiva. En estas circunstancias hemos de preguntarnos si efectivamente el trabajo por cuenta ajena, es decir, el trabajo dependiente, puede ser compatible con esta concepción de consentimiento.

Tal como hemos señalado precedentemente, por definición el trabajo dependiente implica un vínculo de sujeción y de mando, de subordinación y dependencia. En cambio, el consentimiento por definición es libre y necesita desarrollarse en ciertas circunstancias, que permitan desplegar las características que hemos señalado. Si esto no ocurre, el resultado es que no existe consentimiento y en consecuencia se vulnera la libertad sexual. En este orden de cosas, el trabajo dependiente, el proxenetismo con un vínculo de mando es incompatible con el consentimiento y en consecuencia debe ser criminalizado en todos los casos.

Súmese a esto, que a la hora de legalizar hemos de tener en cuenta los problemas que ha enfrentado Holanda, país en donde expresamente se permite que otras personas saquen provecho de la prostitución, ${ }^{242}$ siempre y cuando se registren en los municipios. Destaca el hecho de que el $80 \%$ de las prostitutas son extranjeras y el $70 \%$ carece de documentación, no habiéndose logrado el objetivo de terminar con la clandestinidad y otorgarles derechos. Es ilustrativo el hecho de que en Ámsterdam solo 4 de 250 prostíbulos han firmado convenios con municipalidades, ${ }^{243}$ manteniéndose el resto al margen de la legalidad y ocultando las relaciones laborales bajo otras formas contractuales. Súmese a esto que muchas veces los ayuntamientos son reacios a otorgar licencias o existe una extrema burocracia. ${ }^{244}$

En Holanda se ha vulnerado la legalidad ocultándose los vínculos laborales entre la prostituta y el proxeneta, siendo clandestinos la mayoría de los prostíbulos. En Chile debemos anticiparnos a este fenómeno y en consecuencia establecer una regulación precisa que criminalice a quien ejerza un rol que ponga a la prostituta en una condición se sujeción. De esta forma, los aspectos formales de la relación no serán relevantes, sino el vínculo material que se presenta. Así, por ejemplo, si un proxeneta alega que él solamente arrienda habitaciones a las prostitutas sin existir un contrato laboral o de otra clase, pero en la práctica es comprobado que exigía una cantidad de clientes a la prostituta o cualquier otra clase de condición, debe ser sancionado.

\subsubsection{Legalización del trabajo por cuenta propia y del trabajo asociado}

Sin embargo, ningún reparo nos presenta la legalización del trabajo por cuenta propia o asociado, que ciertamente deben ser regulados para proteger a la prostituta y asegurar sus derechos. Ambos, siempre y cuando no exista un vínculo de sujeción ni de mando, en el caso del trabajo asociado, esto implica que pueden existir ciertas obligaciones funcionales, pero no la imposición concreta de condiciones en la actividad sexual.

\footnotetext{
${ }^{242}$ LOUIS: “Libres de no serlo", cit. nota no 183 , pp. 7 y ss.

${ }^{243}$ LOUIS: "Libres de no serlo”, cit. nota nº 183 , p. 10.

${ }^{244}$ GAY, Sylvia: "Fórmulas jurídicas reconocedoras de los derechos profesionales de las trabajadoras sexuales", en: CERRA, Rosario, Prostitución y Trata, Valencia: Editorial Tirant lo Blanch, 2007, pp. 117-156, p. 152.
} 
Corresponde a las prostitutas establecer la forma de trabajo que más les acomode, sin embargo, la posibilidad del trabajo asociado nos genera especial simpatía, ${ }^{245}$ ya que permite la protección mutua de las trabajadoras y posibilita el goce de otros derechos. Creemos que particularmente las cooperativas deberían ser incentivadas, a través de beneficios tributarios o de otra índole.

Las cooperativas nos parecen adecuadas debido a sus características particulares, ellas son "las asociaciones que de conformidad con el principio de la ayuda mutua tienen por objeto mejorar las condiciones de vida de sus socios y presentan las siguientes características fundamentales: Los socios tienen iguales derechos y obligaciones, un solo voto por persona y su ingreso y retiro es voluntario. Deben distribuir el excedente correspondiente a operaciones con sus socios, a prorrata de aquéllas. Deben observar neutralidad política y religiosa, desarrollar actividades de educación cooperativa y procurar establecer entre ellas relaciones federativas e intercooperativas. Deben también tender a la inclusión, como asimismo, valorar la diversidad y promover la igualdad de derechos entre sus asociadas y asociados". 246

Además, les permitiría tener todos los beneficios de una relación laboral, pero sin que exista realmente un vínculo de trabajo, ya que la misma ley dispone: "Sólo para los efectos previsionales, las cooperativas de trabajo serán consideradas empleadoras y los socios que trabajen en ellas trabajadores dependientes de las mismas, quienes accederán a todos los beneficios que la legislación establece para estos, tales como el subsidio por cargas familiares y el seguro por accidentes del trabajo y enfermedades profesionales". ${ }^{247}$ Además de ello, las cooperativas gozan de beneficios tributarios que otras formas organizacionales no tienen.

En las cooperativas existen principios que fomentan relaciones de colaboración y no de competencia y en consecuencia si la prostitución se organizara de esta forma sería más proclive a la sororidad. En esta misma línea, en las cooperativas existe una igualdad derechos y obligaciones de los asociados y ello lleva a relaciones equitativas. Además los excedentes deben ser repartidos en proporción al esfuerzo y trabajo de los asociados, lo que parece sumamente justo sobre todo en relación a la prostitución.

Creemos que la posibilidad de contagio de una enfermedad venérea es un riesgo del que deben ser resguardadas, por ende, sería conveniente explorar la posibilidad de castigar expresamente al cliente que no usa preservativo o se lo retira sin el consentimiento de la prostituta. Hemos de recordar además que el consentimiento es específico, es decir, se otorga respecto de ciertas actividades y en ciertas circunstancias y el condón es una de ellas, sobre esto volveremos en el apartado siguiente. En cualquier caso, si el Estado considera que es realmente importante el control sanitario de la prostitución, este debería ser traspasado al cliente, por ejemplo, podría establecerse la obligación de portar una cartilla sanitaria que los habilite a contratar con una trabajadora sexual.

\footnotetext{
${ }^{245}$ Sobre algunos de los beneficios del trabajo asociado véase LÓPEZ: "Prostitución y Estatuto", cit. nota $\mathrm{n}^{\circ} 121$, pp. 166-167.

${ }^{246}$ Artículo 1, D.F.L $n^{\circ} 5$ del 2003, 2018. En: https://www.leychile.cl/Navegar?idNorma=221322 [visitado el 01.09.2018].

${ }^{247}$ Artículo 64 inciso 2, D.F.L $n^{\circ} 5$ del 2003, cit., nota ${ }^{\circ} 245$.
} 
Además, es necesario contar con programas de salud tanto psicológica como física, en miras a dar atención a los problemas específicos que podrían presentarse entre ellas ${ }^{248}$ como consecuencia de su trabajo. La existencia de programas psicológicos de calidad sería un gran avance para aquellas que no se sienten a gusto con la actividad o que presentan traumas de infancia o estrés post traumático. Ellos permitirían asegurar la libertad de salida de la prostitución. Además, debe mantenerse la posibilidad de que las prostitutas se efectúen controles gratuitos y confidenciales de enfermedades venéreas.

Es recomendable la implementación de programas de acompañamiento a las prostitutas si deciden trabajar por cuenta propia, pero sobre todo si deciden hacerlo asociadamente. Esto, principalmente con dos objetivos; primero, educarlas sobre sus derechos y la forma y mecanismos para hacerlos efectivos, informándolas de las conductas que se encuentran criminalizadas, de sus beneficios de salud y también interiorizándolas en el consentimiento, libertad sexual y empoderamiento; segundo, informarlas sobre las diversas formas organizativas que pueden adoptar, con sus ventajas y deficiencias.

\subsection{4. ¿Es la regulación penal actual suficientemente protectora? ¿Criminalización del cliente?}

Tal como hemos descrito en el capítulo 5.2, sostenemos que el Derecho Penal debe actuar en todos aquellos casos en que se transgrede el consentimiento. Ya hemos argumentado que el proxenetismo es incompatible con este, pero ¿qué pasa con el cliente? ¿Es suficientemente protectora de los derechos de la prostituta la regulación actual? Hemos caracterizado al consentimiento entre otras cosas como una manifestación de voluntad, un acto que debe ser ejecutado de forma libre. Esto significa que quien consiente debe estar en sus plenas facultades racionales y volitivas. Esto implica que no se puede consentir estando dormido, ebrio o drogado de otra forma, o bien, privado de sentido por cualquier otra causa; tampoco si se padece de alguna incapacidad física que lo impida; o si se tiene un trastorno o enajenación mental. Evidentemente tampoco es posible consentir en caso de que exista fuerza o intimidación de parte de quien pretende una conducta sexual. Es necesario además que quien consiente tenga la edad suficiente para ello, lo que en el caso de la prostitución sería, según la legislación vigente, 18 años (en cuanto a las relaciones sexuales en general sería de 14 años). Como podemos apreciar, las circunstancias descritas precedentemente se condicen con las descritas por el artículo 361 del Código Penal chileno, ${ }^{249}$ relativas a la violación.

En este contexto, hemos de interpretar la disposición del modo en que lo hace Luis Rodríguez Collao, quien considera que lo exigido por el tipo es la ausencia de voluntad (manifestada) o consentimiento y no la oposición de la víctima o el ir contra su voluntad $^{250}$. Sin embargo, creemos que dicha exigencia debiera ser expresa en el tipo de forma que no exista lugar a dudas y yendo un paso más allá, también parece imperativo que el tipo se haga cargo de las exigencias de perdurabilidad y especificidad del

\footnotetext{
${ }^{248}$ Propuesta planteada por ellas mismas, FUNDACIÓN MARGEN: "Fundamentos para un proyecto de ley de Trabajo Sexual", presentación en la V Mesa de Incidencias Políticas para la Regulación del Trabajo Sexual en Chile, Archivo Nacional, 2017.

${ }^{249}$ Artículo 361: (...) Comete violación el que accede carnalmente, por vía vaginal, anal o bucal, a una persona mayor de catorce años, en alguno de los casos siguientes: $1^{\circ}$ Cuando se usa de fuerza o intimidación; $2^{\circ}$ Cuando la víctima se halla privada de sentido, o cuando se aprovecha su incapacidad para oponerse; $3^{\circ}$ Cuando se abusa de la enajenación o trastorno mental de la víctima. Código penal, cit., nota $\mathrm{n}^{\circ} 208$.

${ }^{250}$ RODRÍGUEZ, Delitos Sexuales, cit. nota n 190, p. 189 y ss.
} 
consentimiento. Esto, puesto que es dable pensar que el imputado alegue que existió consentimiento en el acceso carnal, es decir en la introducción del pene en la vagina, boca o ano de la víctima, situación que es la exigida por el tipo. Si el hombre retira el condón en medio de la relación sexual o si en un inicio hay consentimiento, pero éste es retirado y él mantiene su pene dentro de la víctima, una interpretación posible es que de todas maneras el consentimiento fue dado para la penetración y en consecuencia estamos en presencia de una causal de atipicidad. Nuestra opción interpretativa evidentemente es una diversa, puesto que sostenemos que estas características son intrínsecas al consentimiento sexual. Pero, de cualquier manera, es necesario que no exista ningún espacio interpretativo a las alegaciones de un hombre que no asume que el consentimiento debe ser específico y perdurable.

Por otro lado, evidentemente estas circunstancias no abarcan todas las hipótesis de ausencia de consentimiento libre. Podemos imaginar varias situaciones en que no existe consentimiento de una persona mayor de edad, como por ejemplo si padece de un trastorno o anomalía mental que no anula pero sí limita sus facultades volitivas y racionales, caso que no estaría comprendido por el artículo de la violación propia. Un supuesto que podría ser muy común en el marco de la prostitución es el de los episodios de estrés postraumático, por ejemplo. Otra hipótesis que tampoco estaría comprendida en este artículo sería una en que exista cierta relación de dependencia o tal vez vigilancia, como sería, por ejemplo, si un policía pidiera el consentimiento de la prostituta bajo la amenaza de acusarla de proxenetismo; o bien, un arrendador de habitaciones lo hiciera bajo la amenaza de terminar el contrato de arriendo. Por otro lado, es evidente que tampoco existiría un consentimiento libre si la mujer no tiene otra opción de subsistencia que la de prostituirse.

Las situaciones descritas precedentemente han sido recogidas en nuestro Código Penal en el delito de estupro, ${ }^{251}$ pero únicamente respecto de los menores de edad. Esto resulta en extremo problemático cuando hablamos de prostitución, puesto que las prostitutas están permanentemente expuestas al poder de otros agentes. En este mismo sentido Matus y Ramírez efectúan una crítica al artículo en comento, señalando que el legislador ha confundido las situaciones de abuso de inexperiencia -que sí tienen sentido respecto de menores de edad-, con las de abuso de una situación fáctica de poder, que debería tener plena aplicación respecto de mayores de edad. ${ }^{252}$

Estas circunstancias atentan contra un consentimiento libre y por ende deberían ser criminalizadas no solo respecto de las prostitutas sino de todos. Luis Rodríguez Collao señala que lo que subyace a los numerales del artículo 363 es el abuso de una situación de superioridad y la situación de desvalimiento de la víctima. ${ }^{253}$ En consecuencia, en lo que a nosotros respecta, consideramos que los numerales son meramente ejemplares y

\footnotetext{
${ }^{251}$ Artículo 363: Será castigado con presidio menor en su grado máximo a presidio mayor en su grado mínimo, el que accediere carnalmente, por vía vaginal, anal o bucal, a una persona menor de edad pero mayor de catorce años, concurriendo cualquiera de las circunstancias siguientes: $1^{\circ}$ Cuando se abusa de una anomalía o perturbación mental, aun transitoria, de la víctima, que por su menor entidad no sea constitutiva de enajenación o trastorno; $2^{\circ}$ Cuando se abusa de una relación de dependencia de la víctima, como en los casos en que el agresor está encargado de su custodia, educación o cuidado, o tiene con ella una relación laboral; $3^{\circ}$ Cuando se abusa del grave desamparo en que se encuentra la víctima; $4^{\circ}$ Cuando se engaña a la víctima abusando de su inexperiencia o ignorancia sexual. Código penal, cit., nota n ${ }^{\circ} 208$.

${ }^{252}$ MATUS, Jean Pierre; RAMÍREZ, Cecilia, "Lecciones de Derecho Penal Chileno, Parte Especial", Editorial Universidad de Talca, Talca, 2001, p. 78.

${ }^{253}$ RODRÍGUEZ: Delitos Sexuales, cit. nota n ${ }^{\circ} 190$.
} 
por tanto una conducta en que se aproveche una situación de superioridad o el desvalimiento de la víctima, debe ser sancionada igualmente.

Las modificaciones que podrían surgir a la luz de las referidas consideraciones ciertamente serían un avance para las prostitutas, pero también para todas las mujeres de la sociedad. De efectuarse cambios en esta materia, parece innecesaria la criminalización del cliente, puesto que su conducta sería inofensiva y respetuosa de la libertad sexual.

\section{Conclusión}

Hasta aquí hemos analizado un fenómeno tremendamente complejo, que ha variado a lo largo de la historia y que presenta formas infinitamente diversas. Los problemas que se presentan en él son también complejos y es necesario afrontarlos, en este camino hemos adoptado una postura moral y un parámetro de intromisión del Derecho Penal, ambas cuestiones que pueden ser transversales tanto a un feminismo radical como liberal. Hemos visto cómo en Chile existe una completa desprotección de las prostitutas, situación que no puede mantenerse más. Ante esto, hemos planteado varias reformas en miras a garantizar los derechos de las prostitutas.

En primer lugar y como propuesta principal, sugerimos la legalización de esta actividad, estableciendo expresamente que está permitida. Esto, sin lugar a dudas en el caso del trabajo por cuenta propia y asociado, los que deberían contar con programas de asesoría y acompañamiento, en esta misma línea, creemos pertinente realizar políticas de fomento al trabajo asociado, en especial de las cooperativas de prostitutas. Además pensamos que es necesario implementar políticas de protección a los derechos de las prostitutas, deben crearse programas de salud que atiendan a sus requerimientos específicos. En cuanto al trabajo por cuenta ajena, resulta contrario al consentimiento sexual y por ende a la libertad sexual, lo que se ha manifestado en diversos problemas en Holanda. En consecuencia proponemos criminalizar esta clase de proxenetismo. Puntualizamos que no hemos abordado y por ende queda abierto el punto de si el estatuto civil común es apropiado para la prestación de servicios sexuales, en particular en lo relativo a los remedios ante el incumplimiento.

En cuanto a las vulneraciones que pueden sufrir por parte de otros, especialmente del cliente, sostenemos que de existir una regulación penal que tenga por límite el consentimiento en cualquier relación sexual, no sería necesaria la criminalización del cliente. Su conducta puede resultar inocua, no atentatoria de la libertad sexual e incluso moralmente aceptable Además, una medida que podría resultar provechosa es traspasar el control sanitario al cliente. De más está decir que estas ideas pueden y deben ser complementadas con otras.

En tercer y último lugar, rechazamos el castigo penal de la prostitución, tanto cuando se refiere a la prostituta como cuando se refiere al cliente. En lugar de ello, para promover la igualdad, proponemos medidas tendientes a estimular las relaciones caracterizadas por la reciprocidad y el respeto de los deseos y consentimiento de la pareja. Esto debe ser efectuado a través de políticas públicas educativas y no a través de la represión o castigo. Creemos que en esta materia el recurso al poder punitivo es carente de sentido y utilidad. Él aporta a la estigmatización de las trabajadoras sexuales, volviendo su actividad aún más clandestina. La criminalización más que proteger a las prostitutas, 
significaría una vulneración todavía mayor de sus derechos, ya que mantendría a esta labor fuera de la legalidad.

Esta propuesta es feminista puesto que tiene por objeto terminar con la división entre buenas y malas mujeres (o madres y prostitutas) clásicamente machista. Además asume que la sexualidad tiene una doble dimensión para las mujeres, significa a la vez placer y peligro, ninguna de estas dimensiones debe ser desatendida. En último lugar, hemos argumentado a favor de los derechos de las prostitutas y no de su control, sin tener en cuenta ningún argumento moralista -aunque sí hemos tenido en cuenta argumentos morales- carente de razonabilidad y basado en discursos de obscenidad.

Es necesario recordar que la opinión de las trabajadoras debe ser atendida y cualquier política pública debe plasmar su voz y escuchar sus problemas. Además, la regulación debe hacerse en atención a resguardar sus derechos y no a tratarlas como una amenaza social. 


\section{Bibliografía}

AMORÓS, Celia, "El feminismo: senda no transitada de la ilustración", Isegoría, revista de filosofía moral y política, $\mathrm{n}^{\circ} 1,1990$, pp. 129-166

BELTRÁN, Elena, "En los Márgenes del Derecho Antidiscriminatorio: Prostitución y Derechos de las Mujeres", Anales de la cátedra Francisco Suarez n45, 2011, pp. 43-63.

CARMONA, Encarna, “¿Es la prostitución una vulneración de Derechos Fundamentales?", en SERRA, Rosario (Coord.), Prostitución y Trata, Valencia: Editorial Tirant lo Blanch, 2007, pp. 43-70

DE MIGUEL, Ana, "Feminismos", en: AMORÓS, Celia (Dir.), 10 palabras clave sobre Mujer,Pamplona: Editorial Verbo Divino, 1995, pp. 217-253

DE MIGUEL, Ana, "La prostitución de mujeres, una escuela de desigualdad humana", Revista Europea de Derechos Fundamentales, nº19, 2012, pp. 49-74

DE MIGUEL, Ana; PALOMO, Eva, "Los inicios de la lucha feminista contra la prostitución: Políticas de redefinición y políticas activistas en el sufragismo inglés", Brocar, n 35, 2011, pp. 315-334, p 324.

DESPENTES, Virginie, Teoría King Kong, España: Editorial Melusina, 2007.

DIEZ RIPOLLÉS, José Luis, Exhibicionismo, pornografía y otras conductas sexuales provocadoras, España: Editorial BOSCH, 1982.

DUFOUR, Pedro, Historia de la prostitución en todos los pueblos del mundo, Barcelona: Juan Pons, 1870.

GARRIDO, Luis, “La prostitución: Estudio jurídico y criminológico”, Madrid: Edersa, 1992.

GAY, Sylvia; OTAZO, Eñaut; SANZ, Marian, "¿Prostitución = Profesión? Una relación a debate", Aequalitas: Revista jurídica de igualdad de oportunidades entre mujeres y hombres, ${ }^{\circ} 13,2003$, pp. 12-27.

GAY, Sylvia: "Fórmulas jurídicas reconocedoras de los derechos profesionales de las trabajadoras sexuales", en: CERRA, Rosario, Prostitución y Trata, Valencia: Editorial Tirant lo Blanch, 2007, pp. 117-156, p. 152.

GONZALEZ, Manuel, Regulación penal del meretricio, Santiago: Librotecnia, 2009.

HITE, Shere, El orgasmo femenino, teorías sobre la sexualidad humana, Barcelona: Editorial Zeta Bolsillo, 2008.

JAREÑO, Ángeles, "La política criminal en relación con la prostitución: ¿Abolicionismo Legalización?, en SERRA, Rosario (Coord.), Prostitución y Trata, Valencia: Editorial Tirant lo Blanch, 2007, pp. 71-86

JIMÉNEZ DE ASÚA, Luis, "La protección penal del pudor público", El criminalista, tomo V, Buenos Aires: Editorial Víctor P. de Zavalía, 1961.

IGLESIAS, Margarita: "De lacra social a comercio sexual", AÚN CREEMOS EN LOS SUEÑOS (ed.), La prostitución. Debate sobre el derecho a vender el cuerpo: causas de la prostitución; redes internacionales mafiosas; la prostitución infantil, etc., Santiago: Aún creemos en los Sueños, 2004.

KANT, Immanuel, Lecciones de ética, Barcelona: Editorial Crítica, 1988.

LAGARDE, Marcela, Claves feministas para el poderío y autonomía de las mujeres, Nicaragua: Puntos de Encuentro, 1997.

LAMAS, Marta, "Feminismo y prostitución: la persistencia de una amarga disputa", Debate Feminista, n51, 2016, pp. 18-35, pp. 21 y 22.

LARRAURI, Elena, Criminología crítica y violencia de género, Madrid: Editorial Trotta, 2007. 
LARRAURI, Elena, La herencia de la criminología crítica, Madrid: Editorial Siglo XXI, 2000.

LARRAURI, Elena (coord.), Mujeres, Derecho Penal y Criminología, España: Editorial Siglo XXI, 1994.

LIZAMA, Luis, Derecho del Trabajo, Santiago: Editorial Lexis Nexis, 2003.

LÓPEZ, Frederic, "Prostitución y Estatuto Profesional", en: CERRA, Rosario, Prostitución y Trata, Valencia: Editorial Tirant lo Blanch, 2007, pp. 157-202, p. 178.

LÓPEZ, Teresa, “Autonomía”, en: AMORÓS, Celia (Dir.), 10 palabras clave sobre Mujer, Pamplona: Editorial Verbo Divino, 1995, pp. 151-188, p. 175.

LOUIS, Marie Victoire: "Libres de no serlo", AÚN CREEMOS EN LOS SUEÑOS (ed.), La prostitución. Debate sobre el derecho a vender el cuerpo: causas de la prostitución; redes internacionales mafiosas; la prostitución infantil, etc., Santiago: Aún creemos en los Sueños, 2004.

MACKINNON, Catharine, Feminismo inmodificado, Argentina: Editorial Siglo Veintiuno, 2014.

MACKINNON, Catharine, "Prostitution and Civil Rights", Michigan Journal of Gender and-law, vol.1, nº1, 1993, pp. 13-31.

MAQUEDA, María Luisa, “Es la estrategia penal una solución a la violencia contra las mujeres? Algunas respuestas desde un discurso feminista crítico", InDret, Revista para el Análisis del Derecho, n4, 2007, pp. 363-408.

MAQUEDA, María Luisa, "La prostitución: el "pecado" de las mujeres", Cuadernos electrónicos de filosofía del derecho, n³5, 2017, pp. 64-89

MAQUEDA, María Luisa, Prostitución, feminismos y derecho penal, Granada: Editorial Comares S.L, 2009

MATHIEU, Lilian: "Las causas económicas de la prostitución", AÚN CREEMOS EN LOS SUELÑOS (ed.), La prostitución. Debate sobre el derecho a vender el cuerpo: causas de la prostitución; redes internacionales mafiosas; la prostitución infantil, etc., Santiago: Aún creemos en los Sueños, 2004.

MATUS, Jean Pierre; RAMÍREZ, Cecilia, Lecciones de Derecho Penal Chileno, Parte Especial, Talca: Editorial Universidad de Talca, 2001.

MESTRE, Ruth, "Trabajo, igualdad y reconocimiento de derechos", en: CERRA, Rosario, Prostitución y Trata, Valencia: Editorial Tirant lo Blanch, 2007, pp. 1342.

MILL, John Stuart, La esclavitud femenina, Alicante: Fundación Biblioteca Virtual Miguel de Cervantes, 1999. En: http://www.cervantesvirtual.com/obra-visor/laesclavitud-femenina--0/html/fefa4632-82b1-11df-acc7-002185ce6064.html [visitado el 10.09.2018].

MONTREYNAUD, Florence: "Penalización de los clientes en Suecia", AÚN CREEMOS EN LOS SUEÑOS (ed.), La prostitución. Debate sobre el derecho a vender el cuerpo: causas de la prostitución; redes internacionales mafiosas; la prostitución infantil, etc., Santiago: Aún creemos en los Sueños, 2004.

NUSSBAUM, Martha, "El futuro del liberalismo feminista", Areté, n 1, 2001, pp. 59101.

NUSSBAUM, Martha: “Objectification”, Philosophy and Public Affairs, vol. 24, n4 1995, pp. 249-291.

OSBORNE, Raquel: "Debates actuales en torno a la pornografía y a la prostitución", Revista de Sociología, ${ }^{\circ} 30,1988$, pp. 97-105.

OSBORNE, Raquel, La construcción sexual de la realidad, Madrid: Ediciones cátedra, 1993. 
PATEMAN, Carole, El contrato sexual, Barcelona: Editorial Antrophos, 1995. PATEMAN, Carole, "Críticas feministas a la dicotomía público/privado", en: CASTELLS, Carme (Coord.), Perspectivas feministas en teoría política, Barcelona: Editorial Paidós, 1996, pp. 31-52, passim.

PÉREZ, Yolinliztli, "Consentimiento sexual: un análisis con perspectiva de género", Revista Mexicana de Sociología, vol.78 no 4, México, 2016, pp. 741-767.

PULEO, Alicia, "Patriarcado", en: AMORÓS, Celia (Dir.), 10 palabras clave sobre Mujer, Pamplona: Editorial Verbo Divino, 1995, pp. 21-54.

RICOY, Rosa, "Teorías jurídicas feministas", en: FABRA, Jorge Luis; NÚÑEZ, Álvaro (Coord.)Enciclopedia de filosofía del derecho y teoría jurídica, México: Universidad Autónoma de México, 2015, pp. 459-499. En: https://biblio.juridicas.unam.mx/bjv/detalle-libro/3875-enciclopedia-de-filosofiay-teoria-del-derecho-volumen-uno [visitado el 20.10.2017], p. 468.

RIVERA, José, "Algunos apuntes jurídicos sobre la prostitución en Chile", Boletín Mexicano de Derecho Comparado, , n¹48, 2017, pp. 361-392

ROJAS, Irene, Manual de Derecho del Trabajo, Santiago: Editorial Lexis Nexis, 2004.

RODRÍGUEZ, Luis, Delitos Sexuales, Santiago: Editorial Jurídica de Chile, 2014.

RUBIN, Gayl, "Reflexionando sobre el sexo: notas para una teoría radical de la sexualidad", en: VANCE, Carole (Comp.), Placer y peligro, explorando la sexualidad femenina, Madrid: Editorial Revolución, 1989, pp. 113-190.

RUBIO, Gonzalo, “¿Vírgenes o meretrices? La prostitución sagrada en el oriente antiguo", Gerión, n. ${ }^{\circ} 17,1999$, pp. 129-148.

SAEZ, Carolina; ARAVENA, Fabián: "El derecho a ejercer el comercio sexual en Chile", IV Congreso de Teoría Constitucional de la Universidad de Chile, Santiago, 2008.

SÁNCHEZ, Paula, "Trabajo sexual y consentimiento", Ponencia en las Jornadas Noviembre Feminista UCM, Colectivo Hetaira, 2015. Disponible en http://www.colectivohetaira.org/WordPress/trabajo-sexual-y-consentimiento/.

TRIMIÑO, Celina, Aportaciones del feminismo liberal al desarrollo de los derechos políticos de las mujeres, Tesis Doctoral, Universidad Carlos III de Madrid, Getafe, 2010.

VARELA, Nuria: Feminismo para principiantes, España: Ediciones B, 2009.

VASILESCU, Cristina, "Mitos y realidades entorno a la prostitución", InDret $\mathrm{n}^{\circ} 3$, 2017, pp. 1-26.

VERA-GAMBOA, Ligia, "Historia de la medicina. Historia de la sexualidad", Revista Biomedica, vol. 9, n², 1998, pp. 116-121.

VILLACAMPA, Carolina, "Políticas de criminalización de la prostitución: Análisis crítico de su fundamentación y resultados", Revista de derecho penal y criminología, 3.a Época, nº 7, 2012, pp. 81-141.

WALKOWITZ, Judith, Prostitution and Victorian Society, Cambridge: Cambridge University Press, 1980.

WOLLSTONECRAFT, Mary, María, Colección Tras Latitudes, publicada en 1798. En: http://assets.espapdf.com/b/Mary\%20Wollstonecraft/Mary\%20-\%20Maria\%20\%20Mathilda\%20(5665)/Mary\%20-\%20Maria\%20-\%20Mathilda\%20$\% 20 \mathrm{Mary} \% 20 \mathrm{Wollstonecraft.pdf}$ [visitado el 10.10.2017].

ZAFFARONI, Eugenio, "El discurso feminista y el poder punitivo", en: HAYDÉE, Birgin (compiladora), Las trampas del poder punitivo: El género del derecho penal, Argentina: Editorial Biblos, 2000.

\section{Leyes, Tratados e Informes}


Código Civil, 2018. En: https://www.leychile.cl/Navegar?idNorma=172986 [visitado el 01.09.2018].

Código penal, 2018. En: https://www.leychile.cl/Navegar?idNorma=1984 [visitado el 01.09.2018].

Código Sanitario, Santiago, Editorial Thomson Reuters, 2018.

Convenio del Consejo de Europa sobre prevención y lucha contra la violencia contra las mujeres y la violencia doméstica, 2011. En: https://rm.coe.int/1680462543 [visitado el 04.09.2017].

Convenio para la represión de la trata de personas y de la explotación de la prostitución $\quad 1949 . \quad$ ajena, http://www.ohchr.org/SP/ProfessionalInterest/Pages/TrafficInPersons.aspx [visitado el 04.09.2017].

D.F.L $n^{\circ} 5$ del 2003, 2018. En: https://www.leychile.cl/Navegar?idNorma=221322 [visitado el 01.09.2018].

Informe de la unión general de trabajadores: "La prostitución. Una cuestión de género", 2005.

Reglamento sobre Infecciones de Transmisión Sexual, publicado en 2007. En: https://www.leychile.cl/Navegar?idNorma=260650 [visitado el 01.09.2018].

\section{Documentos}

FUNDACIÓN MARGEN: "Fundamentos para un proyecto de ley de Trabajo Sexual", presentación en la V Mesa de Incidencias Políticas para la Regulación del Trabajo Sexual en Chile, Archivo Nacional, 2017.

FUNDACIÓN MARGEN: "Misión y visión", En: http://fundacionmargen.cl/quienessomos/mision-vision/\#.WgD_ytWWbIU [visitado el 28.08.2018].

FUNDACIÓN MARGEN: "Quiénes somos", En: http://fundacionmargen.cl/quienessomos/\#.WgD-N9WWbIU [visitado el 28.08.2018].

GARAIZÁBAL, C: "Una mirada feminista a la prostitución”, Colectivo Hetairas, 2007. En: www.colectivohetairas.org [visitado el 28.08.2018].

"8 de marzo: trabajadoras sexuales en chile recibieron el premio Elena Caffarena 2016”, RedTraSex, En: http://www.redtrasex.org/spip.php?article2263 [visitado el 28.08.2018].

SINDICATO NACIONAL INDEPENDIENTE DE TRABAJADORAS SEXUALES TRAVESTIS, TRANSGÉNERAS Y OTRAS AMANDA JOFRÉ: "Nuestra historia". En: http://www.amandajofre.cl/historia.html [visitado el 28.08.2018]. 